\title{
Cow's milk protein intolerance in infants
}

Citation for published version (APA):

Schrander, J. J. P. (1994). Cow's milk protein intolerance in infants. [Doctoral Thesis, Maastricht University]. Datawyse / Universitaire Pers Maastricht. https://doi.org/10.26481/dis.19940609js

Document status and date:

Published: 01/01/1994

DOI:

10.26481/dis.19940609js

Document Version:

Publisher's PDF, also known as Version of record

\section{Please check the document version of this publication:}

- A submitted manuscript is the version of the article upon submission and before peer-review. There can be important differences between the submitted version and the official published version of record.

People interested in the research are advised to contact the author for the final version of the publication, or visit the DOI to the publisher's website.

- The final author version and the galley proof are versions of the publication after peer review.

- The final published version features the final layout of the paper including the volume, issue and page numbers.

Link to publication

\footnotetext{
General rights rights.

- You may freely distribute the URL identifying the publication in the public portal. please follow below link for the End User Agreement:

www.umlib.nl/taverne-license

Take down policy

If you believe that this document breaches copyright please contact us at:

repository@maastrichtuniversity.nl

providing details and we will investigate your claim.
}

Copyright and moral rights for the publications made accessible in the public portal are retained by the authors and/or other copyright owners and it is a condition of accessing publications that users recognise and abide by the legal requirements associated with these

- Users may download and print one copy of any publication from the public portal for the purpose of private study or research.

- You may not further distribute the material or use it for any profit-making activity or commercial gain

If the publication is distributed under the terms of Article $25 \mathrm{fa}$ of the Dutch Copyright Act, indicated by the "Taverne" license above, 


\section{COW'S MILK PROTEIN INTOLERANCE IN INFANTS}




\section{CIP-GEGEVENS KONINKLIJKE BIBLIOTHEEK DEN HAAG}

Schrander, Jacobus Jan Pieter

Cow's milk protein intolerance in infants / Jacobus Jan

Pieter Schrander. - [S.I. : s.n.] (Maastricht :

Universitaire Pers Maastricht). - III.

Proefschrift Maastricht. - Met lit. opg. - Met samenvatting in het Nederlands.

ISBN 90-9007170-9

Trefw.: allergie en voeding ; zuigelingen / allergie en voeding

; kinderen

Layout and printing: Datawyse / Universitaire Pers

Omslagfoto: Connie Schrander en Jos Offermans, met dank aan de familie Smeets te Sibbe (L) 


\section{COW'S MILK PROTEIN INTOLERANCE IN INFANTS}

\section{PROEFSCHRIFT}

ter verkrijging van de graad van doctor aan de

Rijksuniversiteit Limburg te Maastricht, op gezag van de Rector Magnificus, Prof.dr H. Philipsen, volgens het besluit van het College van Dekanen, in het openbaar te verdedigen op donderdag, 9 juni 1994 om 16.00 uur

door

\section{Jacobus Jan Pieter Schrander}

geboren te Amsterdam op 10 juli 1952

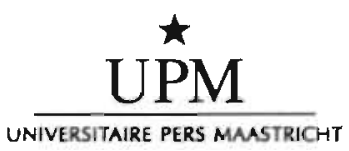




\section{Promotor}

Prof.dr. R.H. Kuijten

\section{Co-Promotor}

Dr. P.P. Forget

Beoordelingcommissie:

Prof.dr. P.B. Soeters, voorzitter

Prof.dr. J.W. Arends

Prof.dr. H.S.A. Heijmans (Rijksuniversiteit Groningen)

Prof.dr. J.M.J.P. van der Linden

Prof.dr. R.W. Stockbrügger

Het in het proefschrift beschreven onderzoek werd mede mogelijk gemaakt dankzij financiële steun van Milupa Nederland. 
Ter gedachtenis aan mijn oma A. Schrander - van Vessum

Voor mijn familie 



\section{CONTENTS}

\section{CHAPTER 1}

General introduction . . . . . . . . . . . . . . . . . . 9

\section{CHAPTER 2}

Aim of the study . . . . . . . . . . . . . . . . 43

\section{CHAPTER 3}

Cow's milk protein intolerance in infants under one year of age:

a prospective epidemiological study.

(Eur J Pediatr 1993;152:640-644) . . . . . . . . . . . . . . . . . . 45

\section{CHAPTER 4}

Diagnostic value of family history, total $\mathrm{IgE}$ and cow's milk RAST in cow's milk protein intolerance. (submitted) . . . . . . . . . . . . 57

\section{CHAPTER 5}

Small intestinal mucosa IgE plasma cells and specific anti cow's milk IgE in children with cow's milk protein intolerance.

(Ann Allergy 1993;70:406-409) . . . . . . . . . . . . . . . . . . . 69

\section{CHAPTER 6}

51-Cr EDTA intestinal permeability in children with cow's milk

protein intolerance. (J Pediatr Gastroenterol Nutr 1990;10:189-192) . . . 79

\section{CHAPTER 7}

Follow up study of cow's milk protein intolerant infants.

(Eur J Pediatr 1992;151:783-785) . . . . . . . . . . . . . . . . . . . . 89

\section{CHAPTER 8}

General discussion . . . . . . . . . . . . . . . . . . . . .97

\section{CHAPTER 9}

Summary . . . . . . . . . . . . . . . . . . . . 103 
CHAPTER 10

Samenvatting

Nawoor

Curriculum vitae 


\section{Chapter 1}

\section{COW'S MILK PROTEIN INTOLERANCE IN INFANTS General introduction}

CONTENTS CHAPTER 1.

1.1 Historical background

1.2 Nomenclature and abbreviations

1.3 Pathophysiology

1.4 Epidemiology

1.5 Clinical manifestations

1.6 Diagnostic aspects

1.7 Prevention

1.8 Treatment 


\subsection{HISTORICAL BACKGROUND}

One of the first authors to report on food intolerance was Hippocrates (460-370 BC). He described a relationship between the occurrence of vomiting, urticaria, headaches and milk. He made mention of persons with severe adverse reactions to food: " He will straightaway feel great loss of strength; his mouth feels bitter; his bowels will seem to hang loose; he will suffer from vertigo, lowness of spirit and inactivity" (cited in 122). One century before Christ, the poet Titus Lucretius mentioned: "that what is food to one, to others is bitter poison" (175). In the 17th century, interrupting the long silence between the first century B.C. and the 20th century, Willis reported an asthmatic attack due to food (cited in 69).

In 1905, allergy was first described by the pediatrician Clemens von Pirquet (143). Together with his fellow pediatrician Bella Shick, he wrote several reports on serum sickness. The Greek words "allos", meaning different or changed, and "ergos", meaning work or action, were combined in the term "allergy". After the introduction of the allergy concept, several reports dealing with food allergy were published. In 1921, Prausnitz described the experiment with his allergic patient and colleague Küstner. He transferred serum from his fish-allergic colleague to his own arm. The next day, Prausnitz was injected with fish extract and developed a positive skin reaction, the Prausnitz-Küstner reaction (134). The factor thought responsible for this was named reagin by Coca and Cooke in 1922 (134). It was not until 1966, when IgE was simultaneously discovered by Ishizaka et al $(91,92)$ and by Johansson and Bennick $(97)$, that the so-called reagin became IgE. Kjellman (100) made use of serum IgE levels to differentiate between allergic (high values) and non-allergic people (low values). Lindberg and Arroyave reported (121) age-related normal values. Soon after this discovery, the measurement of allergen-specific IgE, the Radio Allergo Sorbent Test (RAST), was described (190).

One of the first reports of adverse reactions to cow's milk was made by Hamburger (1901). His article dealt with patients whose prolonged diarrhoea and failure to thrive was attributed to an adverse reaction to cow's milk (75). In 1905, Finkelstein wrote about cow's milk as a cause of feeding problems in infants (59). He described anaphylactic shock in relation to cow's milk leading to death in one of his patients. Abt (1) reported in 1912 that some infants had severe symptoms due to an adverse reaction ("idiosyncrasy") to cow's milk. In 1929. Cohen (34) wrote one of the first articles on milk allergy as a common cause of symptoms in infants. At that time, it was regarded as rare, since nearly all studies took only the most severe reactions into consideration $(59,178)$. In 1944 , Brodibb (25) described less serious problems in infants, such as vomiting. which were all relieved by milk avoidance. 
In contrast to the period 1900 - 1950, when reports concerning cow's milk protein intolerance (CMPI, an abnormal response to cow's milk protein) were scanty, the number of reports on the subject increased significantly in the subsequent decades $(9,33,69,72,94,178)$. Several factors were responsible for this increase, including the decline of breast-feeding, the improved knowledge of immune mechanisms, advances in our understanding of nutrition and the recognition of less severe adverse reactions to cow's milk.

Clein (33) reported in 1954 that approximately one out of every fifteen infants was allergic to cow's milk to some degree. He also described the major differences in presentation of CMPI. One infant might display mild colic or "spitting up" when allergic to milk, another might collapse from a few drops of milk placed upon the tongue. In 1957, Bachmann and Dees (9) were one of the first authors to publish a study on the incidence and symptoms of cow's milk allergy. The CMPI diagnosis in his article, and in almost all articles until Goldman's publication in 1963, was based on case history and clinical improvement following milk elimination. In most instances, oral challenges were not used.

In 1963, Goldman et al (72) made a detailed description of milk intolerance symptoms in a large group of children; for the first time, clear clinical diagnostic criteria for CMPI were presented.

In the Netherlands, interest emerged in the late 1960s when a committee of the Dutch Nutritional Council and the Dutch Pediatrics Society indicated growing awareness of the problem following the appearance of reports in the literature mentioning symptoms due to CMPI. Slooff (168) made an inquiry amongst Dutch pediatricians to find out whether they had treated children with cow's milk allergy. The questionnaire was answered by almost all clinical pediatricians. 15 Cases of probable cow's milk allergy were reported and 11 of them were accepted as CMPI. More years had to pass before a realistic view on CMPI appeared.

Due to terminological differences, the lack of reliable laboratory diagnostic tests and the practical problems encountered in performing milk elimination/challenge tests, much confusion and scepticism conceming CMPI still persists today.

\subsection{NOMENCLATURE AND ABBREVIATIONS}

The terminology of adverse food reactions has been a continual topic of discus= sion and international agreement has not yet been achieved $(40,53,58,129,141)$. The first chapter of a book on food intolerance, edited by John Dobbing in 1987 (141), deals with the problems of terminology. 
There is even some discussion about the common term "food intolerance". Two widely used definitions are: "a reproducible, adverse reaction to a specific food or food ingredient which is not psychologically based" (116) or "a nonimmunological abnormal physiological response to food" (131). The second definition does not comprise food allergy. In the present thesis, and in agreement with the definition given by the British Nutrition foundation, we use the term cow's milk intolerance for any abnormal response to milk intake which is not psychologically based and the term cow's milk allergy, a type of intolerance, defined to be an immunological reaction resulting from the ingestion of milk (116). We also make use of the term Cow's Milk Protein Intolerance (CMPI) $(94,186)$ to indicate a reproducible intolerance to cow's milk proteins.

In the Netherlands, a slightly different terminology was agreed on during a consensus meeting on "voedselovergevoeligheid" (food hypersensitivity) in 1990 (132): food hypersensitivity is used as a broad term which can be divided into food intolerance (no immune reaction), food allergy (an immune reaction) and food aversion (a purely psychological reaction). Toxic reactions (food toxicity), meaning adverse food reactions due to contaminants, is not included in the term food hypersensitivity. This terminology could not be integrated into this thesis since the terms used were decided upon in 1987.

One of the problems with the terminology is that it often differentiates between immunological and non-immune reactions on the basis of serum IgE levels, RAST results or skin prick tests, while it does not take into account the possibility of local $\mathrm{IgE}$-mediated reactions or other immunological reactions.

\subsubsection{Terms and abbreviations used}

Milk hypersensitivity:

a broad term used to cover all reactions to milk intake, with the exception of toxic reactions.

Milk intolerance:

a reproducible abnormal reaction to milk which is not psychologically based.

Milk allergy:

an immunologically based adverse reaction resulting from the ingestion of milk.

Cow's milk protein intolerance (CMPI):

an abnormal response to cow's milk protein.

\section{Milk toxicity:}

an adverse reaction to milk occurring in normal individuals due to the presence of a contaminant in the milk. 
RAST:

Radio Allergo Sorbent Test.

$\operatorname{IgE}$ :

Immunoglobulin E.

\subsection{PATHOPHYSIOLOGY}

Possibly due to the etiological heterogeneity and to gaps in our understanding of the subject, no definite description can be given of the pathophysiology of CMPI. Immunological disturbances, mostly secondary to inherited genetic factors, probably underlie the majority of adverse reactions to milk proteins (165).

\subsubsection{Genetic factors}

From the genetic point of view, atopy, defined as an $\operatorname{lgE}$ responsiveness, is a complex disease and familial aggregation is a long established feature (37). Both genetic and environmental factors have to be taken into account. Gene frequency in the population is $20-30 \%$, the prevalence being lower in infants and children, higher in young adults and declining thereafter (38). Most family studies showed a pattern consistent with an autosomal dominant pattern of inheritance. In an Oxford population, DNA linkage analysis placed the locus for IgE responses underlying asthma and rhinitis on the long arm of chromosome 11 (11q13) $(38,39,194)$. The genetic linkage to $11 \mathrm{q} 13$ was not confirmed in other studies $(2,88,124,149)$. Linkage with chromosome 6 (the HLA system) has been suggested but not confirmed (2). Confounding factors in genetic studies on atopy are the high population prevalence, genetic heterogeneity and the possible selection bias in designing the study. The number of genes involved in atopy is still unknown. Environmental factors influence the clinical manifestation of atopy. Whether atopy is inherited from the father or the mother may be an important factor $(39,153)$. Linkage analysis data in the Oxford study show a significantly higher maternal inheritance of $\operatorname{IgE}$ responsiveness underlying asthma and rhinitis (39). Clinical data in families with atopic dermatitis show that the risk of a child being affected is 4.7 times higher in maternal transmission as compared to paternal transmission (153). These data can be explained with paternal genomic imprinting or with maternal modification of the infant's immunological responses. Gerrard et al (67) found a significant difference in family history between a sick control group and CMPI patients when considering allergic mothers or siblings (not fathers). Empirical data (67) showed that 
milk hypersensitivity appears to be more common in relatives of patients with CMPI than in the general population. Reliable genetic data have not yet been reported in families with CMPI.

\subsubsection{Antibodies to cow's milk in infants}

Circulating antibodies to cow's milk are usually absent in serum of newborns or are present only in low titres. Any circulating antibodies to cow's milk detected at birth have been in almost all cases of the IgG class and their titres were comparable to those circulating in the mother. When normal newborn infants are fed cow's milk, IgG antibodies to milk are detected during the first month and reach a peak at three months. IgA antibodies to milk develop more slowly, reaching a peak at seven months (10). Circulating $\operatorname{IgG}$ and $\operatorname{IgA}$ antibodies to cow's milk proteins are always produced when a child gets cow's milk. No difference in the level of $\mathrm{IgA}$ and $\mathrm{IgG}$ antibodies to cow's milk are seen among patients with positive or negative reactions to cow's milk challenges (162). Total $\mathrm{IgE}$ levels increase in most individuals during childhood (121). In some cases, $\mathrm{IgE}$ antibodies to cow's milk can develop early in infancy and are associated with CMPI (154).

\subsubsection{Possible factors leading to gut immunological reactions}

In order to elicit an immunological reaction, milk antigens have to reach the mucosal immunocompetent cells while maintaining an antigenic structure. A defect in antigen exclusion, $\lg \mathrm{A}$ deficiency, decreased effectiveness of luminal proteolysis and disruption of the mucosal barrier to antigens are thought to lead to enhanced penetration of intact antigens resulting in immune-mediated reactions. These factors play an important role in the development of cow's milk intolerance $(52,184,186)$. Transmucosal penetration of antigens is a sine qua non for the development of allergic reactions to milk.

Mucosal reactions to incoming antigens can lead to either tolerance or hypersensitivity reactions. In animal tests, exposure of the gut associated lymphoid tissue (GALT) to antigens has been shown to induce a local IgA response mediated by $\operatorname{IgA}$ helper T-cells and at the same time to suppress $\mathrm{IgGr}$ and $\mathrm{IgE}$ systemic responses, resulting in oral tolerance to the ingested antigen. Suppressor T-cells can be activated in Peyer's patches in response to antigen presentation and these suppressor T-cells are supposed to migrate to peripheral lymphoid tissue where suppression of systemic immune responses occurs (150). Regulation of these immune reactions is not yet well understood and seems to depend on several factors such as age and antigen dose (170). Many pediatric diseases are accompanied by an increased gut permeability. The cause of this altered 
permeability is uncertain, but in sensitive infants the enhanced penetration of intact antigens does lead to immune-mediated reactions (184). Failure of immunoregulation is the most probable cause of allergic milk reactions (105).

\subsubsection{Immunological reaction types}

According to Coombs and Gell (40), all four types of immune reactions have been described in infants with CMPI.

a: Type I reaction: $\operatorname{IgE}$ mediated reaction, immediate hypersensitivity. This reaction has often been reported in CMPI $(11,43,44,61,77,82,89,99,103,121$, 154,156,177). In 1961, a study by Hanson and Mansson (77) showed that cow's milk has at least 18 protein components which can induce antibody formation. The most important antigens in cow's milk are the whey proteins (10-16\%) (beta lactoglobulin, alpha lactalbumin and a small fraction bovine serum albumin) and the caseins (75-86\%). Hurnan milk is notably devoid of beta lactoglobulin (98). Heat stability is highest for caseins, lowest for serum albumin and intermediate for beta lactoglobulin (98). The most antigenic components are beta lactoglobulin (77) and casein.

IgE antibodies to cow's milk can be shown in plasma (154), skin (156), intestinal lumen (126) and intestinal mucosa (63). The T-cell regulation of IgE synthesis differs between allergic individuals and normal persons (182). Serum IgE levels are elevated in approximately $60 \%$ of allergic patients (113). T-cells and mast cells produce interleukin-4 (IL4) and induce IgE production in B cells, while at the same time inhibiting the production of other immunoglobulins (36). Reddy et al (148) recently reported that elevated levels of IL4, soluble CD23 and $\mathrm{CD} 20+\mathrm{CD} 23+$ lymphocytes may play a role in the increased production of $\operatorname{IgE}$ in atopic subjects in vivo. Further findings will have to shed more light on the precise mechanism of IgE-regulated immune responses.

b: Type II reaction: antibody-mediated injury to cells. Milk antigens could stick passively to the cell surface components and later be bound by soluble antibodies or interact with complexes near cell membranes, resulting in cell destruction. Milk-induced thrombocytopenia has been cited as a possible example (104).

c: Type III reaction: antigen-antibody complex formation. This reaction has been shown to take place in normal individuals. Complexes can contain IgA, IgG and milk proteins. In allergic patients, the amount of complexes is much higher and they may contain specific $\operatorname{IgE}$ in association with anti- $\operatorname{IgE}$ antibodies. These complexes may appear 30 minutes after milk ingestion $(21,70,117,155)$. 
The relationship of circulation and deposition of complexes to milk-related diseases is difficult to evaluate. Milk antigen-associated immune complexes have been found in Heiner syndrome (79).

\section{d: Type IV reaction: $T$-cell mediated delayed hypersensitivity reactions.}

T-cell sensitization to milk antigens and additives can occur (104). Ashkenazi et al (6) and Hill et al (84) showed production of leucocyte inhibitory factor (LIF) in children with a delayed type of CMPI. Most infants with a delayed type of hypersensitivity do not show an IgE-mediated reaction (84). LIF production has also been shown in healthy control children and infants with an acute type of hypersensitivity, but these two groups produced less LIF when compared to patients with a delayed type of CMPI (84).

\subsubsection{Inflammatory processes}

Virtually every known cellular and non-cellular mediator system has been implicated in milk sensitive reactions: mast cells and basophils can be triggered by IgE antigen interactions on cell membranes, free immune complexes, complement system components such as anaphylatoxins (C3a and C5a) and by various chemicals (98). Activation of neutrophils, macrophages, eosinophils, platelets and lymphocytes as cellular events in cow's milk hypersensitivity has been reported (184). A raised production of prostaglandins, leukotrines (115) and interleukin-2 (87) has been reported, as well as decreased production of interferon-gamma in infants with CMPI (171). Interferon-gamma will suppress the capacity to generate an $\operatorname{IgE}$ response from the start $(148,171)$, while interleukin-4 (IL4) induces IgE production $(36,148)$. A better knowledge of inflammatory parameters will probably improve our insight into the mechanisms underlying CMPI.

\subsubsection{Conclusion}

In the present state of understanding, most authors consider that one or more immunological reaction types are implicated in CMPI $(118,140)$. At a symposium of the European Nutritionists Group in Scheveningen (1990), Lessof (118) concluded that, despite all the published work on this topic, it has still not been proven that reactions other than type-I reactions (according to the classification of Coombs and Geli) are involved in CMPI. Recently, Esteban (50) confirmed that possible roles of immune complex-mediated reactions, delayedtype reactions, or antibody-mediated cytotoxic effects remain to be established.

Further studies concerning type-I reactions should be pursued. Perhaps looking specifically for IgE-mediated reactions at the level of the intestinal mucosa can improve our insight into immunological processes in CMPI. 


\subsection{EPIDEMIOLOGY}

Reported incidence rates of CMPI in infants range from $0.3 \%$ to more than $10 \%$ $(37,68,192,193)$. These large differences can be attributed to the use of variable diagnostic criteria, such as the number of milk challenges used $(37,47,68$, $169,179,180,192)$, differences in patient selection $(16,37,47,68,133,169,179$, $180,181,192)$, types of feeding regime $(94,169)$ and differences in study design, such as retrospective evaluation in some studies $(123,169)$ and prospective in others $(68,94)$. The incidence of CMPI decreases with age $(23)$. This suggests that intestinal and/or immunological maturity might be of importance for the development of CMPI.

In the Netherlands in 1988, Douwes et al (47) reported an epidemiological study of CMPI in infants less than 6 months of age which showed an incidence rate of $3.5 \%$ in the region of Amsterdam. In this first study in the Netherlands, only one elimination/challenge test was performed in most infants.

There appears to be a need for a well-standardized prospective study in order to be able to more precisely evaluate the CMPI incidence rate in infants.

\subsection{CLINICAL MANIFESTATIONS OF CMPI}

A study of the literature reveals that many symptoms have been associated with CMPI $(13,52,68,122)$. The most frequent symptoms reported are gastrointestinal, occurring in 50\% of infants with CMPI. Dermatological and respiratory symptoms are mentioned next $(24,68,81,192)$ (Table 1). Most symptoms of CMPI develop in young infants under 6 months of age and the majority of infants has multiple symptoms (68).

Depending upon how patients are ascertained a varying proportion will have intolerance to other foods. Diagnostic criteria, such as the number of milk challenges, having a positive immunological test, patient selection, types of feeding regime, differences in study design (22) explain this variation. Bishop et al (16) found that more than $50 \%$ of the infants with CMPI exhibited other food intolerances (Table 2). Some of these infants had positive skin tests and elevated IgE antibodies to these substances. A cow's milk challenge can induce strong immune responses to unrelated dietary antigens concomitantly present in the intestinal lumen (172). This could explain the development of multiple intolerances in infants with CMPI. Some responses are probably due to a non-immune mechanism, such as a high incidence of diarrhoea induced by eating fruit. 


\section{Table 1:}

Clinical features of CMPI:

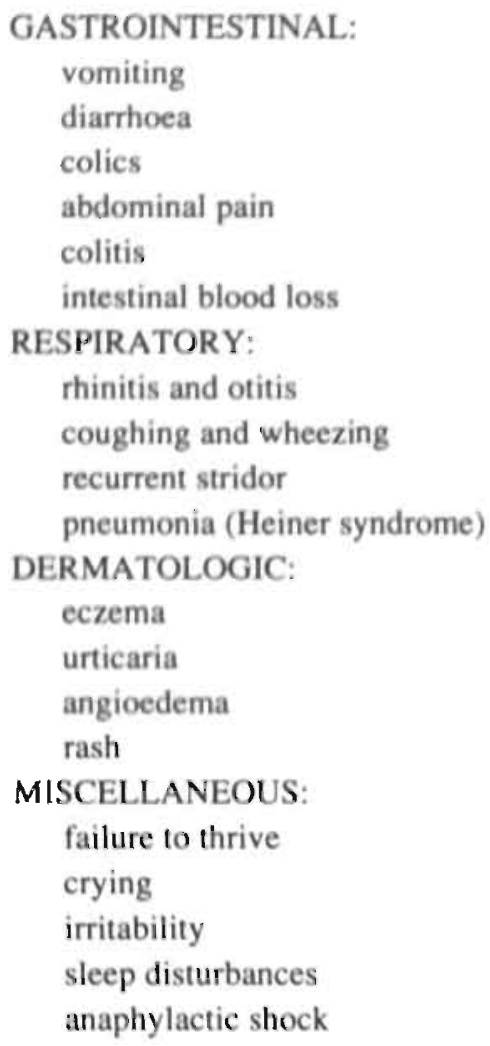

\subsubsection{Gastrointestinal problems}

a: Enteropathy: Infants with cow's milk enteropathy can show protracted diarrhoea, vomiting, failure to thrive and colics $(4,68,74)$. The pathological changes in the intestinal mucosa can be similar to celiac disease but are much less severe in most cases $(161,180)$.

b: Colitis: Infants with cow's milk colitis show diarthoea with blood and mucus. Jenkins et al (95) studied 46 children with ulcerative colitis; 8 infants were under 2 years of age and recovered after elimination of cow's milk and beef. Biopsies showed an eosinophilic infiltration of the colon mucosa. 
Table 2:

Top ten of associated food intolerances in children with CMPI:

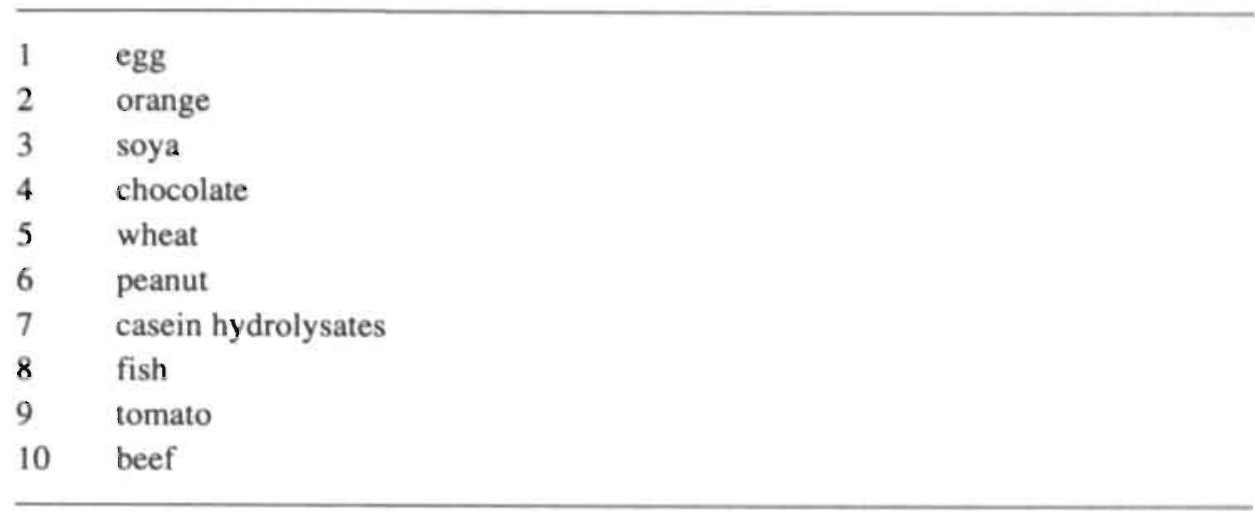

Derived by Bishop et al (16)

c: Eosinophilic gastroenteropaihy is a rare disorder with intestinal protein and iron loss and is also associated with CMPI (183). The symptoms consist of wasting, edema and ascites. In most cases, symptomatology does not start in the first months of life. There is an eosinophilic infiltration of the gastric, small intestinal and colon mucosa.

$d$ : Infantile colics are characterized by bouts of excessive prolonged crying for 2 - 3 hours or more $(34,68,122)$. The incidence of colics in CMPI patients has been reported to be about $30 \%(13,68,72)$. In infants with colics as a main symptom, Taubman (174) had more success with parental counselling than with cow's milk removal. This author reduces the role of cow's milk in colics.

$e:$ Other gastrointestinal manifestations, such as occult gastrointestinal blood loss with (35) or without (60) anaemia, sporadic cases of pyloric spasm (25) and necrotic enterocolitis (187) have been reported.

\subsubsection{Dermatological problems}

About $35 \%$ of infants with CMPI display dermatological manifestations, especially atopic dermatitis $(72,111)$.

a: Atopic dermatitis: Up to $50 \%$ of infants with atopic dermatitis have been reported to have CMPI (85). Most infants with atopic dermatitis have elevated serum IgE. Several reaction types have been described. Sampson and Mc (jaskill (157) described $\operatorname{IgE}$ and RAST positive infants, most of whom reacted within 
two hours after milk intake. As reported by Atherton (7), the majority of patients with a non-IgE mediated eczema show reactions only days or weeks after milk intake.

b: Oral allergy syndrome: the symptoms are localized especially in the mouth and consist of intra-oral and lip irritation and angioedema. These symptoms may be accompanied by urticaria around the mouth, rhinitis, conjunctivitis and sometimes even systemic manifestations. In the majority of cases, a reaction occurs within minutes after milk intake $(3,137)$.

c: Urticaria and angioedema: Approximately $10 \%$ of infants with CMPI develop generalized urticarial reactions $(85,111)$. In these children, a risk of anaphylactic shock has to be taken into account.

d: Other skin manifestations: Exanthema and occasional perianal eruptions have been reported (85).

\subsubsection{Respiratory problems}

The incidence of respiratory symptoms in patients with CMPI varies from 10 $35 \%$; upper respiratory problems and asthma are particularly prominent ( 33 , $46,72)$.

a: Asthma: Amongst infants with CMPI, the frequency of asthma (wheezy bronchitis) is about $10 \%-30 \%(33,68,72)$. Bock et al (22) showed in wheezy children with CMPI that the respiratory symptoms were always combined with dermal or gastrointestinal symptoms. Only a limited number of people with asthma show evidence of milk hypersensitivity (136). Symptoms can occur immediately or gradually after a delay of several hours following ingestion of milk (191).

b: Heiner syndrome: Heiner et al described a syndrome consisting of a non-infectious pneumonitis with shifting infiitrates, eosinophilia, failure to thrive and pulmonary hemosiderosis, chronic rhinitis and recurrent otitis media (79). The occurrence of this syndrome has not been confirmed by other groups. The symptoms could also be attributed to recurrent milk aspiration (114). It is an uncommon manifestation of CMPI but of interest due to the presence of a possible type III immunological reaction (antigen-antibody complex formation) in these patients. 
c: Upper respiratory tract disease: The association of rhinitis and otitis media with CMPI is controversial. In previous series by Goldman et al (72), Gerrard et al (68), Hill and Hoskins (85) and Clein (33), percentages of $10-30 \%$ are mentioned in infants with CMPI. In a prospective study on CMPI, Jacobsson and Lindberg (94) report rhinitis to be a rare symptom. Bahna (11) considers that milk allergy is probably too frequently ignored as a cause of persistent upper respiratory tract symptoms.

\subsubsection{Miscellaneous}

a: Anaphylactic shock: One of the most feared reactions to milk has been described in one of the first reports on CMPI (59). Lifshitz et al (119) reported an infant having three episodes of anaphylactic shock, the first time while drinking breast-milk. The risk of shock has been used quite often to warn against cow's milk challenges, especially in infants with severe atopic eczema $(45,72)$. When challenges are done with appropriate precautions, anaphylactoid reactions can be avoided (83).

b: Many diseases have been associated with CMPI. A manifestation may be almost exclusively due to C.MPI or may result from the combined effects of several triggers in which C.MPI is only one of several possible causes of a symptom or disease (58). Milk has been mentioned several times as an etiological factor in case histories concerned with enuresis noctuma (52), diabetes mellitus (127), migraine (49), rheumatoid arthritis $(147,196)$, nephrotic syndrome (159), attention deficit and hyperkinesia disorder (ADHD) and tension fatigue syndrome (8). This list can be expanded with a great number of diseases in childhood. In addition, a relation between Sudden Infant Death Syndrome and CMPI has been reported (41). The relation between cow's milk intake and most of the above diseases is still under debate (192).

\subsection{DIAGNOSIS}

\subsubsection{Introduction}

The nonspecific character of the clinical manifestations and the often delayed onset are responsible for the difficulties involved in prompt recognition of the disease. In a comment on McCarty and Frick's 1983 article entitled "Milk hypersensitivity: keys to diagnosis" (129), the editor of the Journal of Pediatrics writes: "We take pleasure in printing this article, because we believe that it represents a major step in resolving the chaos, uncertainties, and heated debates over milk sensitivities, well known to all practising physicians". 
In 1992, much confusion still exists because of difficulties in terminology $(116,131,141)$, the lack of objective and reproducible diagnostic tests for all age groups (13) and the problems around the number and methodology of elimination/challenge tests $(9,13,42,72)$.

Cow's milk in one form or another is ingested by infants daily in quantities exceeding those of any other single food. Obviously, the simplest and most convincing way of establishing the presence of cow's milk protein intolerance would be to demonstrate an altered immune reaction to cow's milk protein. A number of tests have been proposed but no single test can fulfil this goal.

\subsubsection{Immunological tests}

The great majority of authors look for type I Coombs and Gell allergic reactions $(121,154)$.

a: IgE-mediated tests in serum and skin: The skin prick test (SPT) and the radio allergo absorbent test (RAST) are commonly used in CMPI for the detection of IgE-mediated reactions. SPT and RAST have given variable results, including iesurts whicn do not correfate with each other and taise positive and taise negative results. Sampson (158) reported that only $35 \%$ of the infants with atopic dermatitis with a positive skin test or RAST showed a positive reaction after oral challenge. According to Hoffman and Haddad (89), the SPT in particular gave more positive results than could be justified by history and provocation tests. Other authors do not see much difference between RAST and SPT results $(144,156)$.

Sensitivity and specificity of the RAST differ greatly between authors. Sensitivity for cow's milk RAST varies from $44 \%-88 \%$ and for specificity from $35 \%-87 \%(20,158,173)$. The inclusion of the most common individual milk protein fractions in the RAST may or may not enhance its diagnostic usefulness $(13,14)$. The heterogeneous clinical and immunological findings in studies of infants with CMPI could be due to patient selection.

Hill et al (84) discriminated three groups of children. An immediate reacting group (within 45 minutes) having mainly urticarial and angioedematous eruptions, an intermediate reacting group (between 45 minutes - 20 hours) with mainly gastrointestinal symptoms and a late reacting group (after 20 hours) showing atopic dermatitis, bronchitis and or diarrhoeal symptoms. The immediate reacting group had mostly positive skin test reactions to milk and elevated total and milk specific IgE serum antibody levels in comparison with the other two groups. Much overlap exists between the three groups. 
Weck (189) reported a 3.5\% occurrence of a positive cow's milk RAST in a normal infant population. In his book "Food and food additive intolerance in childhood", David concludes that RAST and skin testing are of little use in the diagnostic work up of food intolerance (44).

b: Tests for intestinal IgE-mediated reactions: In several milk intolerant patients with both negative RAST and skin prick test, Marcucci et al (126) reported the presence of specific IgE against milk allergens in intestinal washings. Forget and Arends (63) reported the presence of mucosal IgE plasmocytes in several children with cow's milk intolerance. For further information conceming intestinal reactions, see under 1.6.4.

c: Other immunological tests for CMPI, such as ELISA, determination of leucocyte migration inhibition factor, lymphocyte proliferation test, leucocyte histamine release, immune complex assessment, complement fixation and im munofluorescence studies on intestinal biopsy specimens are research tools and have not yet been shown to be sufficiently reliable for routine diagnosis (13).

d: Combining immunological tests: Tainio and Savilahti (173) made an evaluation of several immunological tests. In children with symptoms suggestive of CMPI they measured serum levels of immunoglobulin $G, A, M$, and $E$, complement fractions 3 and 4, class specific cow's milk antibodies, as well as the numbers of different lymphocyte subsets and the responses of whole blood lymphocytes to stimulation by phytohemagglutinin concanavalin $\mathrm{A}$ and beta lactoglobulin. The best combination they found was measurements of cow's milk specific IgE and the index of lymphocyte stimulation with beta lactoglobulin. This combination had a sensitivity of $88 \%$ and a specificity of $67 \%$. Räsänen et al (146) used five skin and laboratory tests in diagnosing CMPI. The tests used were prick and patch tests, RAST, basophil histamine release test and lymphocyte proliferation test. Specificity and sensitivity using these five tests were $95 \%$ and $58 \%$. These studies underline the dramatic lack of reliable laboratory tests.

\subsubsection{Intestinal permeability test}

A defective mucosal barrier at the level of the gastrointestinal mucosa is thought to play an important role in the development of cow's milk protein intolerance (188). An increased permeability probably is not the primary cause of CMPI (80). Many pediatric diseases show an increased gut permeability such as acute gastroenteritis $(18,62,64,96,135)$, chronic gastroenteritis $(62,163)$, celiac disease $(17,65,76,96,176)$, Crohn's disease $(96,160,176)$, necrotizing enterocolitis $(187,188)$, recurrent abdominal pain $(130)$, cystic fibrosis $(112,135)$, malnutri- 
tion $(15,51)$, milk allergy $(4,56,76,163)$ and atopic eczema $(64,142)$. The lack of specificity of intestinal permeability tests is the main drawback for routine use of these tests. Most of the diseases can be easily excluded in the differential diagnosis of CMPI. Only scanty data are available concerning the relationship between intestinal permeability and antigen permeability. In a study performed in rats, a relationship between permeability for protein and that for $51-\mathrm{Cr}$ EDTA has been shown to exist (145). If these results also apply to children antigen $^{2}$ exposure of mucosal immunocompetent cells would be increased in many intestinal inflammatory conditions, and CMPI would only develop in those babies showing a disordered function of the mucosal immune system. Milkintolerant children (4), as well as patients with atopic eczema $(64,142)$, can show increased gut permeability. One of the common features of these diseases is the importance of allergy in their etiology. No study had been done to look for a clinical use of the 51-Cr EDTA permeability test in infants having symptoms possibly due to CMPI.

\subsubsection{Intestinal biopsies}

Intestinal biopsy findings in over 50 infants with CMPI and gastrointestinal symptoms, especially chronic diarrhoea, vomiting and failure to thrive, were published by Kuitunen et al (108). Small bowel biopsies showed var̃ying degrees of enteropathy in the majority of patients. The most severely affected patients showed total mucosal atrophy, as in celiac disease. Various degrees of villous atrophy, inflammatory infiltrates and decrease in mucosal thickness have been mentioned by Maluenda et al (125). Shiner et al (166) suggested that ultrastructural and immunological changes could be helpful for the diagnosis. Patterson et al (139) showed IgE plasmocytes in human intestinal mucasa with immuno-electron microscopy. Increased numbers of $\mathrm{IgE}$ plasmocytes have been reported in spirochaetosis (73) and in proctitis (78). Forget and Arends (63) and Rosekrans et al (151) reported the presence of mucosal IgE plasmocytes in several children with cow's milk intolerance. However, Savilathi (161) did not confirm these results.

No study had been done to look for a clinical use of the mucosal IgE plasmocytes in infants having symptoms possibly due to CMPI.

\subsubsection{Elimination/challenge tests with cow's milk}

The main problem in studying infantile CMPI is that placebo-controlled studies with milk are very difficult to perform with infants and according to Bahna (12) are rarely needed. Apari from the poor taste and different smell, the composition of a protein hydrolysate visibly differs from a milk containing infant feeding. An experienced physician even can smell whether a child has taken a hydrolysate 
or not; the stools become watery and green. At the beginning of the present study consultation with Nutricia (Netherlands) and Milupa (Germany) did not result in an infant feeding which could be used in a realistic double blind controlled study. The only possibility would have been to hospitalize the infants not allowing parents and doctor's involved in the study to visit the infants. For some infants it took several days to develop clear symproms on cow's milk. Ethically this would not have been realistic. At the symposium on "Adverse reactions to foods in infancy and childhood" held in Madrid, Spain in 1992, Dr Walker Smith stated that, ethically, one cannot do double-blind challenges in infants. Thus the diagnosis of CMPI has to be based on adverse clinical responses to open cow's milk challenges. One has to remember that when a double blind challenge procedure is used in older patients to assess a possible adverse reaction to a given food, in May's study, only $40 \%$ of supposedly allergic patients have a positive challenge (128). In patients with gastrointestinal symptoms, lactose intolerance has to be excluded first $(94,185)$. In most cases of CMPI, cow's milk protein elimination will result in clinical improvement and milk protein reintroduction will cause a relapse, which will again disappear on elimination of cow's milk. Some authors accept the diagnosis after one positive milk elimination/challenge test, while others rely on two positive elimination/challenge tests and only a minority of authors still use Goldman's criteria (72) based on three elimination/challenge tests. These criteria are as follows: a) symptoms subside after dietary elimination of cow's milk; b) symptoms recur within 48 hours after cow's milk challenge; c) reactions to three such challenges must be positive and have similar onset, duration and clinical features. Because of confusing data in the literature, we looked in our study at the number of challenges that were needed for the diagnosis of CMPI (164). In a group of infants having symptoms possibly due to cow's milk protein, we studied the diagnostic impact of performing one, two and three elimination/challenge tests with cow's milk. After one, two and three elimination/challenge tests, $53 \%, 18 \%$, and $5 \%$ respectively of our patients appeared to tolerate cow's milk. After the third elimination/ challenge test, two children $(5 \%)$ did not show a recurrence of symptoms. During followup, one of these two infants developed an allergy for fish, eggs and meat. We concluded that one elimination/challenge test was not sufficient for the diagnosis of cow's milk protein intolerance and that three elimination/challenge tests were not necessary to confirm the diagnosis (164). The risk of anaphylactic reaction should be considered especially in infants with urticaria and or angioedema (45). 


\subsubsection{Differential diagnosis}

a: Lactose intolerance can mimic the gastrointestinal complaints due to CMPI (especially diarrhoea) and causes recurrence of symptoms after cow's milk challenge (186). Therefore lactose intolerance has to be excluded before cow's milk protein elimination/challenge tests can be performed.

b: Gastroesophageal reflux also can mimic CMPI. Vomiting and prolonged crying are known symptoms and the age of occurrence is almost the same as with CMPI (13).

c: Many other conditions are associated with symptoms very similar to those of CMPI (Table 1). Cow's milk can be etiologically important in some infants with a disease or symptom or it can be an important or just a minor irritant which aggravates symptoms of the underlying illness in other children. Examples of several diseases are given in paragraph 1.5.4.b.

\subsubsection{Concluding remarks}

No single test or combination of tests can as yet be used for a reliable diagnosis of CMPI (156). Two positive cow's milk elimination/challenge tests after exclusion of lactose intolerance remain the best way to diagnose CMPI. The value of $\mathrm{IgE}$ and milk RAST combined with family history, intestinal permeability test and intestinal biopsies should be assessed in a prospective study.

\subsection{PREVENTION}

The effect of dietary interventions in infants for prevention of CMPI and atopic disease has been studied extensively. Several studies use ill defined allergy criteria such as "family history positive for allergy" in order to select infants. Epidemiological and genetic data of atopic diseases have to be known in order to know which infant is to be considered for such a study. In seven-year-old children, Kjellman (102) reported a total incidence of atopic disease of $15 \%$. With one atopic parent, the incidence was $20 \%$ and with two atopic parents, $43 \%$ atopic children were found. When parents had similar symptoms the incidence rose to $70 \%$. Do we have to select two atopic parents to consider prevention?

The prevention of CMPI and allergy by dietary intervention has been the subject of conflicting reports. Dietary interventions during pregnancy and lactation have been studied extensively $(27,30,31,32,99,167,195)$. 


\subsubsection{Dietary prevention during pregnancy}

It is interesting to consider for a nutrient the possibility of intra uterine sensitization since it could lead to preventive dietary measures during pregnancy. Kurome et al (109) in 1976 and Kondo et al (106) in 1990 reported intrauterine sensitization for food allergens. In a review article, Wilson and Hamburger (192) advised women with a positive history for atopy to use an allergen avoidance diet for the last trimester of the pregnancy. No follow up of this advice has been reported. Kjellman (101) reported weight loss in the third trimester as the only objective result of such an advice.

The question whether atopic symptoms in children would be preventable stimulated Falth-Magnusson and Kjellman $(54,55,57)$ to perform a number of interesting studies conceming this question. In their study a group of 209 atopic mothers were totally abstained from cow's milk and egg from gestational week 28 until delivery. A five-year follow-up did not show any preventive effect of an elimination diet during late pregnancy on allergic disease in the genetically predisposed child.

Zeiger et al (195) cast doubt on the benefit and safety of instituting foodavoidance diets prenatally in an attempt to modify allergic disease in infancy. Chandra et al (31) also showed that antigen avoidance during pregnancy did not result in a decreased incidence of CMPI and atopy in infants.

Lilja et al and Zeiger et al $(120,195)$ failed to show any influence of diet on cord IgE levels, or on cord-specific antibodies to cow's milk or egg. During a food allergy workshop (101), Kjellman commented on the literature of intrauterine sensitization: there are very few studies showing it and one of the major drawbacks of these studies is the possible contamination of fetal blood with maternal blood when determining IgE. In order to control for contamination simultaneously $\mathrm{IgE}$ antibodies have to be determined in maternal serum to see whether the mother's IgE antibodies are also present in cord blood.

Furthermore food antibody levels in colostrum are similar in atopic and nonatopic mothers. Low allergen diet during pregnancy had no influence on the colostrum antibody levels nor did high levels of antibodies offer protection against food allergies in infants (54).

In conclusion antigen avoidance during pregnancy does not result in a decreased incidence of CMPI or atopy in infants. 


\subsubsection{Dietary intervention during lactation or use of hypoallergenic formulas in infants}

The effect of dietary interventions in infants for prevention of CMPI and atopic disease was reported in a review of 24 papers in 1983 (27). In half of the reported studies, a relationship between cow's milk and late allergic disease was found. Duration of breast-feeding between the groups varied between 2 weeks and 6 months (19)!

In 1988 Kramer (107) assessed 35 articles in a review article: "Does breastfeeding help protect against atopic disease? Biology, methodology, and a golden jubilee of controversy" (Table 3 ).

Table 3:

Does breast-feeding protect against atopy?

\begin{tabular}{lrr}
\hline & yes & no \\
\hline Atopic dermatitis & 9 & 12 \\
Asthma & 7 & 6 \\
Allergic rhinitis & 3 & 4 \\
Atopy & 5 & 3 \\
\hline
\end{tabular}

Derived by Kramer (107)

Several criteria were developed by Kramer conceming diverse aspects of exposure, outcome and statistical analysis. Many shortcomings were rectified. He concluded that the positive studies (breast-feeding protects against allergy) were somewhat stronger. He advocated that further studies should improve in respect both of design and analysis to avoid another era of controversy. Almost no study reported a worse result of breast-feeding on the risk for developing atopic symptoms.

Jakobsson and Lindberg (93) showed the influence of cow's milk in the diet of breast-feeding mothers on symptoms (especially colics) in their infants. In the same year, Killshaw et al (98) demonstrated milk and egg proteins in breastmilk. Since these publications most articles concerning breast-feeding and the development of atopy deal with a matemal allergen avoidance during breastfeeding.

Zeiger et al (195) performed a randomized study in order to look at the effect of maternal and infant milk allergen avoidance for 24 months. He saw a lower cumulative prevalence of allergy in the antigen avoidance group in the first year of life. Chandra et al (30) concluded from a well-performed study that in families with a history of atopic eczema, mothers who breast-feed should avoid the 
ingestion of common allergenic foods during lactation. In infants who are not breast-fed, a hydrolysate formula should be used. In another study, Chandra et a! (32) concluded that feeding a whey hydrolysate formula to infants at high risk of atopy reduces the incidence of atopic disease and that this approach is significantly better than feeding a soy-based formula. In the same study, he showed that breast-feeding without dietary restriction was less successful than breast-feeding with a diet. Looking at recent data (1992) on maternal avoidance of cow's milk, eggs and fish for 3 months during lactation, Sigurs et al (167) showed a significant reduction in the cumulative incidence and prevalence of atopic dermatitis at the age of 4 years. No other differences were found concerning the incidence of atopic manifestations. The authors also claimed a significantly lower number of positive skin prick tests and specific $\mathrm{IgE}$ antibody reactions.

Arshad et al (5) studied the effect of combined allergen avoidance on the development of allergic diseases. Not only did an allergen-avoidance diet for the lactating mother decrease the influence of allergic symptoms, but exposure to house dust mites and smoking were risk factors which influenced the incidence of atopic manifestations as well.

Chandra (29) discussed the cost-benefit ratio in respect of the health problems of atopic persons and preventive programs. He claimed that preventive strategies would be cost-effective. He looked at the situation in Newfoundland where 200,000 children live. The therapy costs for atopic manifestations would be 7 million dollars every year. The costs of a preventive program: 1 million dollars, including hypoallergenic formulas. If atopy could be reduced by $20 \%$, this preventive strategy would be cost-effective. For the Dutch situation, the costs would be about 140 million guilders for therapeutic expenses and 20 million per year for a preventive program.

The end point upon which to advocate antigen avoidance during lactation in atopic families on a large scale has not been reached yet. Larger randomized studies over a longer period of time have to be done in order to definitely determine whether or not the promising preliminary results on some atopic manifestations can be confirmed.

\subsection{TREATMENT}

Is there an ideal treatment for CMPI? Purely eliminating cow's milk would be sufficient. No difficulties would develop introducing other foods instead of cow's milk. Problems such as palatability, intolerance for the new formula, the costs for society and especially for parents should be avoided. The problem, especially in infants, is their dependence on a infant formula. 


\subsubsection{Elimination of cow's milk}

Elimination of cow's milk and of products containing cow's milk proteins is required in CMPI. Mothers who are breast-feeding should avoid cow's milk and other highly allergenic foods in their diet $(30,45,85)$. In the case of bottle-fed infants, a cow's milk infant formula substitute can be used.

\subsubsection{Goat's milk}

Goat's milk is not a suitable substitute for cow's milk due to high levels of fat, proteins and minerals (86). Furthermore, anti-cow's milk IgE produced by children allergic to cow's milk reacted with goat's milk. The whey protein fraction of goat's milk shows considerable cross-reactivity with the whey proteins of cow's milk (71).

\subsubsection{Soy protein-based formulas}

About 10-25\% of infants with CMPI develop a hypersensitivity to soy milk $(66,94,138)$. Soy proteins are reported as potentially antigenic, but allergic reactions to soy seem to occur less frequently than those to cow's milk proteins (185). The antibody formation would be the same as with cow's milk (48). Still, the great majority of cow's milk intolerant infants accept soy milk. Because adapted soy milk infant formula is cheaper and has a better palatability than protein hydrolysates, it is widely used.

\subsubsection{Protein hydrolysate formulas}

Several proteins such as casein, whey, soy and collagen are used for the preparation of protein hydrolysate formulas. Protein hydrolysis by enzyme reduces the antigenicity and allergenicity of protein (110). The disadvantages of these formulas are their bad taste and high costs. It is very difficult to determine whether various hydrolysed formulas differ in their efficacy (110). The allergenicity of the hydrolysed formulas is less than that of soy formulas (32). Recently, Rugo et al showed a slight advantage in residual allergenic activity for casein hydrolysates (152). Seldom an elemental, amino acid-based formula has to be used. 


\subsubsection{Ass milk formula}

Iacona et al (90) described a group of 9 infants with CMPI and allergic reactions to a semi-elemental formula. They used ass milk successfully in this small group of infants with multiple food allergy. A new approach to CMPI? Normal ass milk is not suitable as a cow's milk substitute for infants!

\subsubsection{Medication}

Theoretically prevention of sensitization to cow's milk would be the best way to avoid CMPI. A better knowledge of inflammatory parameters will probably innprove our insight into the mechanisms underlying CMPI. Interferon-gamma suppresses the capacity to generate an IgE response, while interleukin- 4 induces IgE production $(36,148)$. The possibility of interfering with the inflammatory response should be further investigated. As allergic reactions can be blocked by cromolyn, oral cromolyn can be used in their prevention. Oral cromolyn can be prescribed when milk allergy cannot be managed by dietary restriction alone. In a small but well performed study of eight children (26), no benefit from cromolyn sodium could be demonstrated. In a double-blind crossover trial with children whose atopic dermatitis was due to milk allergy, Buscinco et al (28) showed that sodium cromoglycate reduces the exacerbations of atopic dermatitis caused by milk allergens. André et al (4) elegantly showed the beneficial effects of oral cromoglycate on intestinal permeability and post-challenge symptoms. New data on results of other medications are scarce and mostly unverified. New drugs have to be developed that show clear results in a majority of patients with CMPI. 


\section{REFERENCES}

1. Abt IA. Milk as a food for infants. Chicago M Rec 1912;16-24.

2. Amelung PJ, Panhuysen CIM, Postma DS, Levitt RC, Koeter GH, Francomanos CA, Bleecker ER, Meyer DA. Atopy and bronchial hyperresponsiveness: exclusion of linkage to markers on chromosomes $11 \mathrm{lq}$ and 6p. Clin Exp Allergy 1992;22:1077-1084.

3. Amlot $\mathrm{PL}_{\text {" }}$ Kemeny DM, Zachary C, Parkes, Lessof $\mathrm{MH}$. Oral allergy syndrome: symptoms of IgE-mediated hypersensitivity to foods. Clin Allergy 1987;17:33-42.

4. André C, André F, Colin L, Cavagna S. Measurement of intestinal permeability to mannitol and lactulose as a means of diagnosing food allergy and evaluating therapeutic effectiveness of disodium cromoglycate. Ann Allergy 1987:59:127-130.

5. Arshad Sh, Matthews S, Gant C, Hide DW. Effect of allergen avoidance of development of allergic disorders in infancy. Lancet 1992;339:1493-1497.

6. Askhenazi A, Levin S, Idar D. In vivo cell-mediated immunological assay for cow's milk allergy. Pediatrics 1980;66:399-402.

7. Atherton DJ. A double-blind controlled crossover trial of an antigen avoidance diet in atopic eczema. Lancet 1978;: I:401-404.

8. Atkins FM. Food allergy and behaviour: definitions, mechanisms and a review of the evidence. Nutrition Reviews 1986;5 suppl:104-112.

9. Bachman KD, Dees SC. Milk allergy. Observations on incidence and symptoms of allergy to milk in allergic infants. Pediatrics 1957;32:400-407.

10. Bahna SL, Ghandi MD. Milk hypersensitivity. Pathogenesis and symptomatology. Ann Allergy 1983;50:218-223.

11. Bahna SL. Pathogenesis of milk hypersensitivity. Immunol Today 1985;6:153.

12. Bahna SL. Milk allergy in infancy. Ann Allergy 1987;59:131-136.

13. Bahna SL. Milk allergy. In: Chiaramonte LT, Schneider AT, Lifshitz F, eds. Food Allergy. A practical approach to diagnosis and management, 1st ed. New York and Basel: Marcel Dekker 1988:107-116.

14. Basayaı JP, Mallet E, Brunelle P, de Menibus CH. Les intolerances au lait de vache. Etude des immunoglobulines E specifiques. Presse Med 1983; 12:2041-2043.

15. Behrens R., Lunn PG, Northrop CA, Hanlon PW, Neale G. Factors effecting the integrity of intestinal mucosa of Gambian children. Am J Clin Nutr 1987:45:433-441.

16. Bishop JM, Hill DJ, Hosking CS. Natural history of cow milk allergy: clinical outcome. J Pediatr 1990; i 16:862-867.

17. Bjarnason I, Peters TJ, Veall N. A persistent defect in intestinal permeability in celiac disease demonstrated by a 51-Cr-labeled EDTA absorption test. Lancet 1983;I:323325.

18. Bjarnason I, O'Morain C, Levi AJ, Peters TJ. Absorption of 51-chromium-labeled ethylenediaminetetraacetate in inflammatory bowel disease. Gastroenterology 1983; 85:318-322.

19. Bjorksten B. Does breast-feeding prevent the development of allergy? Immunol Today 1983:4:215-217.

20. Bjorksten B, Ahlstedt S, Bjorksten F, Carlsson B, Fallstrom SP, Juntunen K, Kajosaari D, Kober A. Immunoglobulin E and immunoglobulin G4 antibodies to cow's milk in children with cow's milk allergy. Allergy 1983;38:119-124.

21. Bleumink. E. Immunological aspects of food allergy. Proc Nutr Soc 1983; 42(2):219231. 
22. Bock SA, Lee WY, Remegio LK, May CD. Study of hypersensitivity reactions to food in infants and children. J Allergy Clin Immunol 1978;62:327-334.

23. Bock SA. The natural history of food sensitivity. J Allergy Clin Immunol 1982;69:170177.

24. Bock SA. Prospective appraisal of complaints of adverse reactions to foods in children during the first 3 years of life. Pediatrics 1987;79:683-688.

25. Brodibb HS. Vomiting in infants. Arch Dis Childh 1944;19:140-144.

26. Burks WA, Sampson H. Double blind placebo-controlled trial of oral cromolyn in children with atopic dermatitis and documented food hypersensitivity. J Allergy Clin Immunol 1988;81:417-423.

27. Burr ML. Does infant feeding affect the risk of allergy? Arch Dis Childh 1983;58:561565.

28. Buscinco L, Benincori N, Nini G, Buscinco E, Cantani A, Angelis M. Double-blind crossover trial with oral sodium cromoglycate in children with atopic dermatitis due to food allergy. Ann Allergy 1986;57:433-438.

29. Chandra RK. Nahrungsmittelallergie: 1992 und danach. Sozialpädiatrie in der Püdiatrie 1993; 15supl:232-237.

30. Chandra RK, Puri S, Hamed A. Influence of matemal diet during lactation and use of formula feeds on development of atopic eczema in high-risk infants. Br Med J 1989; 299:228-230.

31. Chandra RK, Puri S, Suraya C, Cheema PS. Influence of maternal food antigen avoidance during pregnancy and lactation on incidence of atopic eczema in infants. Clin Allergy 1986;16:563-569.

32. Chandra RK, Singh G, Shridhara B. Effect of feeding whey hydrolysate, soy and conventional milk formulas on incidence of atopic disease in high-risk infants. Ann Allergy 1989;63:102-106.

33. Clein NW. Cow's milk allergy in infants. Pediatr Clin N Am 1954;4:949-962.

34. Cohen M. Milk allergy. Am J Dis Childh 1929;38:741-745.

35. Coello-Ramirez P, Larrossa-Harro A. Gastrointestinal occult haemorrhage and gastroduodenitis in cow's milk protein intolerance. J Pediatr Gastroenterol Nutr 1984;3:215218.

36. Coffman R1, Ohara J, Bond MW. B-cell stimulatory factor I enhances the IgE response of lipopolysaccharide-activated B-cells. J Immunol 1986;136:438-44 I.

37. Collins WC. The incidence of milk allergy in pediatric practice. J Pediatr 1956;48:3947.

38. Cookson WOCM, Sharp PA, Faux JA, Hopkin JM. Linkage between immunoglobulin E responses underlying asthma and rhinitis and chromosome I Iq. Lancet 1989;1:12921294.

39. Cookson WOCM, Young RP, Sandford AJ, Moffatt MF, Shirakawa PA, Sharp PA, Faux JA, Julier C, Le Souef PN, Nakumura Y, Lathrop GM, Hopkin JM. Matemal inheritance of atopic IgE responsiveness on chromosome 11q. Lancet 1992;340:381384.

40. Coombs RRA, Gell PHG. Classification of allergic reactions responsible for clinical hypersensitivity and disease. In: Gell PHG, Coombs RRA, Lachman PJ, eds. Clinical aspects of immunology, 3rd ed. Oxford: Blackwell Scientific Publications 1975:761782.

41. Coombs RN, Holgate ST. Allergy and cot death: with special focus on allergic sensitivity to cow's milk and anaphylaxis. Clin Exp Allergy 1990;20:359-366. 
42. Cummings NP, Allan Bock S. Clinical methods to diagnosis. In: Chiaramonte LT, Schneider AT, Lifshitz F, eds. Food Allergy. A practical approach to diagnosis and management, Ist ed. New York and Basel: Marcel Dekker 1988: 289-300.

43. Danneus A, Johansson SGO, Foucard T. II Clinical and immunological aspects of food allergy in childhood. Acta Paediatr Scand 1978;67:497-504.

44. David TJ. Food and food additive intolerance in childhood. Blackwell Scientific Publications Oxford 1993:58-65.

45. David TJ. Anaphylactic shock during elimination diets for severe atopic eczema. Arch Dis Child 1984;59:983-986.

46. Davies W. Cow's milk allergy in infancy. Arch Dis Child 1958;33:265-270.

47. Douwes AC, Weert-Waltman ML van, Folkertsma K, Fagel JFM, Verboom WSW. Prevalentie van voedselallergie bij Amsterdamse zuigelingen. Ned Tijdschr Geneesk 1988;132:1392-1396.

48. Eastham EJ, Lichauco T, Gardy MI, Walker WA. Antigenicity of infant formulas, J Pediatr 1978;93:561-564.

49. Egger J, Carter C, Wilson J, Turner MW, Soothill JF. Is migraine a food allergy? A double-blind controlled trial of oligo-antigenic diet treatment. Lancet 1983;II: 865-869.

50. Esteban MM. Adverse food reactions in childhood; concept, importance and present problems. J Pediatr 1992;121 suppl:1-3.

51. Elia M, Goren A, Behrens R, Barber RW, Neale G. Effect of total starvation and low calorie diets on intestinal permeability in man. Clin Sci 1987:73:205-210.

52. Esperanca M, Gerard JW. Noctumal enuresis. Can Med Assoc J 1969;101:721-724.

53. Eugene P, McCarty, Frick OL. Food sensitivity: keys to diagnosis. J Pediatr 1983; 102:645-652.

54. Falth-Magnusson K. Breast-milk antibodies to foods in relation to maternal diet, maternal atopy and the development of atopic disease in the baby. Int Arch Allergy Appl Immunol 1989;90:297-300.

55. Falth-Magnusson K, Kjellman NI. Allergy prevention by maternal diet during late pregnancy: a 5-year follow-up study. J Allergy Clin Immunol 1992;89:709-713.

56. Falth-Magnusson K, Kjellman NI, Odelram H, Sundqvist T, Magnusson KE. Gastrointestinal permeability in children with cow's milk allergy: effect of milk challenge and sodium cromoglycate as assessed with polyethyleneglycols (PEG 400 and PEG 1000). Clin Allergy 1986;16:543-551.

57. Falth-Magnusson K, Kjellman MD. Development of atopic disease in babies whose mothers were receiving exclusion diet during pregnancy. A randomized study. J Allergy Clin Immunol 1987:80:868-875.

58. Ferguson A. Definitions and diagnosis of food intolerance and food allergy: Consensus and controversy. J Pediatr 1992;121 suppl:7-11.

59. Finkelstein H. Kühmilch als Ursache akuter Emährungs Störungen bei Sauglingen. Monatschr Kinderheilkd 1905; 4:65-72.

60. Fomon SJ, Ziegler EE, Nelson SE, Edwards BB. Cow's milk feeding in infancy: gastrointestinal blood loss and iron nutritional status. J Pediatr 1981;88:541-545.

61. Ford RPK, Hill DJ, Hosking CS. Cow's milk hypersensitivity: immediate and delayed onset of clinical patterns. Arch Dis Childh 1983;58:856-862.

62. Ford RPK, Menzies IS, Philips AD, Walker-Smith JA, Turner MW. Intestinal sugar permeability: relationship to diarrhoeal disease and small bowel morphology. J Pediatr Gastroenterol Nutr 1985;4:568-574. 
63. Forget $\mathrm{P}$, Arends JW. Cow's milk protein allergy and gastro-esophageal reflux. Eur J Pediatr 1985;144:298-300.

64. Forget PP, Sodoyez-Goffaux F, Zappitelli A. Permeability of the small intestine to 51-Cr EDTA in children with acute gastroenteritis or eczema. J Pediatr Gastroenterol Nutr 1985;4:393-395.

65. Fotherby KJ, Wraight EP, Neale G. 51-Cr EDTA/14C Mannitol intestinal permeability test. Clinical use of coeliac disease. Scand J Gastroenterol 1988;23:171-177.

66. Francis DE. Diets for sick children, 4th ed. Oxford: Blackwell Scientific Publications 1988.

67. Gerrard JW, Lubos MC, Hardy LW, Holmlund BA, Webster D. Milkallergy: Clinical picture and familial incidence. Can Med Ass 1967;97:780-784.

68. Gerrard JW, MacKenzie JWA, Goluboff N, Garson JZ, Maningas CS. Cow's milk allergy: prevalence and manifestations in an unselected series of newborns. Acta Paediatr Scand 1973;234 suppl:1-21.

69. Gifford CG. Food Allergy. A contemporary review of clinical and immunological advances. Paediatrician 1976;5:215-227.

70. Gjesing B, Lowenstein H. Immunochemistry of food antigens. Ann Allergy 1984; 53:602-608.

71. Gjesing B, Osterballe O, Schwartz B, Wahn U, Lowenstein H. Allergen specific IgE antibodies against antigenic components in cow's milk and milk substitutes. Allergy 1986;41:41-56.

72. Goldman A, Anderson DW, Sellers WA, Saperstein S, Kniker W'T, Halpern SR. Milk allergy: I. Oral challenge with milk and isolated milk proteins in allergic children. Pediatrics 1963;32:425-43.

73. Grebbers JO, Ferguson DJ, Mason C, Crucioli V, Jewell DP. Lokale Immunreaktion bei Intestinaler Spirochätose des Menschen. Schweiz Med Wochenschr 1987;45:10871091.

74. Gryboski JD. Gastrointestinal milk allergy in infants. Pediatrics 1967;40:354-362.

75. Hamburger F. Biologisches über die Eiweisskörper der Kühmilch und über Süuglingsemährung. Wien Klin Wochenschr 1901;1:1202-1204.

76. Hamilton I, Hill A, Bose B, Bouchier IA, Forsyth JS. Small intestinal permeability in pediatric clinical practice. J Pediatr Gastroenterol Nutr 1987;6:697-701.

77. Hanson LA, Mansson I. Immuno-electrophoretic studies. Acta Pediatr 1961;50:483490.

78. Heatley R, Calcraft BJ, Fifield R, Rhodes J, Whitehead RH, Newcastie RG. Immunoglobuline $E$ in rectal mucosa of patients with proctitis. Lancet 1975; II: 1010-1012.

79. Heiner DC, Sears JW, Kniker WT. Multiple precipitins to cow's milk in chronic respiratory disease. A syndrome including poor growth, gastrointestinal symptoms, evidence of allergy, iron deficiency anemia and pulmonary hemosiderosis. Am J Dis Childh 1962;103:634-654.

80. Heyman M, Grasset E, Ducroc R, Desjeux J. Antigen absorption by the jejunal epithelium of children with cow's-milk allergy. Pediatr Res 1980;24:197-202.

81. Hide D, Guyer B. Clinical manifestations of allergy related to breasi-milk and cow'smilk feeding. Arch Dis Childh 1981;56:172-175.

82. Hill DJ, Davidson GP, Cameron DJS, Bames Gi. The spectrum of cow's milk aliergy in childhood. Acta Paediatr Scand 1979;68:847-852.

83. Hill DJ, Firer MA, Shelton MJ, Hosking CS. Manifestations of milk allergy in infancy: Clinical and immunological findings. J Pediatr 1986;109:270-276. 
84. Hill DJ, Ball G, Hosking CS. Clinical manifestations of cow's milk allergy in childhood. I. Associations with in vitro cellular immune responses. Clin Allergy 1988; 18:469-479.

85. Hill DJ, Hoskins CS. Cow's milk allergy. In: David TJ, ed. Recent advances in pediatrics, 9th ed. London: Churchill Livingstone 1991:187-206.

86. Hilton PA. Is goat's milk suitable for feeding young children? Nutr Fd Sci 1983;85:1518.

87. Hiroatsu Agata, Naomi Kondo, Osamanu Fukutomi, Shinji Shinoda, Tadao Orii. Interleukin-2 production of lymphocytes in food-sensitive atopic dermatitis. Arch Dis Childh 1992;67:280-284.

88. Hizawa N, Yamaguchi E, Ohe M, Itoh A, Furuya, Ohnuma N, Kawakami Y. Lack of linkage between atopy and locus 1 Iq 13. Clin Exp Allergy 1992;22:1065-1069.

89. Hoffman DR, Haddad ZH. Diagnosis of IgE-mediated reactions to food antigens by radio-immuno-assay. J Allergy Clin Immunol 1974;54:165-170.

90. Iacona G, Carroccio A, Cavataio F, Soresi M, Balsamo V. Use of ass' milk in multiple foodallergy. J Pediatr Gastroenterol Nutr 1992;14:177-181.

91. Ishizaka K, Ishizaka T, Hornbrook MM. Physiochemical properties of human reaginic antibody: IV Presence of a unique immunoglobulin as a carrier of reaginic activity. J Immunol 1966:97:75-85.

92. Ishizaka K. Mechanism of reaginic hypersensitivity. Clin Allergy 1971;1:9-24.

93. Jakobsson I, Lindberg T. Cow's milk proteins cause infantile colic in breast-fed infants: a double-blind crossover study. Pediatrics 1983;71;268-271.

94. Jakobsson I, Lindberg T. A prospective study of cow's milk intolerance in Swedish infants. Acta Paediatr Scand 1979;68:853-859.

95. Jenkins HR, Priscolt JR, Soothill JF, Milla PJ, Harries JT. The major cause of infantile colitis. Arch Dis Childh 1984;59:326-329.

96. Jenkins RT, Jones DB, Goodacre RL, Collins SM, Collins G, Hunt RA, Bienenstock J. Reversibility of increased intestinal permeability to 51-Cr EDTA in patients with gastrointestinal inflammatory diseases. Am J Gastroenterol 1987;82:1159-1164.

97. Johansson SGO, Bennich H. Immunological studies of an atypical (myeloma) immunoglobulin. İmmunology 1967;73:38 1-385.

98. Kilshaw PJ, Heppel LMJ, Ford JE. Effects of heat treatment of cow's milk and whey on the nutritional quality and antigenic properties. Arch Dis Childh 1982;57:842-847.

99. Kilshaw PJ, Cant AJ. The passage of maternal dietary proteins into human breast-milk. Int Arch Allergy Appl Immunol 1984;14:533-541.

100. Kjellman N-I M. Immunoglobulin E and atopic allergy in childhood. Linkoping University Medical Dissertations 1976:36.

101. Kjellman N-I M. Allergy prevention: does maternal food intake during pregnancy or lactation influence the development of atopic disease in infancy? In: Kanson LA,ed. Biology of human milk. Nestlé Workshop Series 1986:15.

102. Kjellman N-I M. Atopic disease in seven-year-old children: incidence in relation to family history. Acta Paediatr Scand 1977;66:465-468.

103. Kjellman N-I M, Bjorkstein B, Hattevig G, Falth-Magnusson K. Natural history of food allergy. Ann Allergy 1988:61:83-87.

104. Kniker WT. Immunologically mediated reactions to food: state of the art. Ann Allergy 1987:59:60-70. 
105. Kniker WT, Rodriquez M. Non-IgE-mediated and delayed adverse reactions to foods or additives. In: Breneman JC, ed. Handbook of food allergies, Ist ed. New York and Basel: Marcel Dekker 1987:125-161.

106. Kondo N, Kobayashi Y, Shinoda S, Kasahara K, Kameyama T, Iwasa S, Oril T. Cord blood lymfocyte responses to food antigens for the prediction of allergic disorders. Arch Dis Childh. 1992;67:1003-1007.

107. Kramer MS. Does breast-feeding help protect against atopic disease? Biology, methodology, and a golden jubilee of controversy. J Pediatr 1988;112:181-190.

108. Kuitunen P, Visakorpi JK, Savilathi E, Pelkonen P. Malabsorption syndrome with cow's milk intolerance, clinical findings and course in 54 cases. Arch Dis Childh. 1975:50:351-356.

109. Kurome T, Oguri M. Matsumura T. Milk sensitivity and soya-bean sensitivity in the production of eczematous manifestations in breast-fed infants with particular reference to intrauterine sensitization. Ann Allergy 1976;37:41-45.

110. Leary HL. Nonclinical testing of formulas containing hydrolyzed milk protein. J Pediatr 1992;suppl 121:42-46.

111. Lebenthal E. Cow's milk protein allergy. Pediatr Clin N Am 1975:22:827-833.

112. Leclercq J, Forget PP, Sodoyez-Goffaux F, Zappitelli A. Intestinal permeability to 51-Cr EDTA in children with cystic fibrosis. J Pediatr Gastroenterol Nutr 1986:5:384387.

113. Lee $\mathrm{B}$. IgE response and its regulation in allergic diseases. Pediatr Clin $\mathrm{N}$ Am 1988;35:953-967.

114. Lee S, Knicker W, Cook C, Heiner D. Cow's-milk-induced pulmonary disease in children. In: Bamess L., ed. Advances in Pediatrics. Chigago: Year Book Publishers 1978.

115. Lessof MH, Anderson JA, Youlten LJF. Prostaglandines in the pathogenesis of food intolerance. Ann Allergy 1983;51:249-250.

116. Lessof MH. Food intolerance and food aversion. A joint report of the Royal College of Physicians and the British Nutrition Foundation. J Royal College Physicians London 1984; 18:83-123.

117. Lessof MH, Kemeny DM. Non-IgE-mediated reactions to food: how much is allergic? Ann Allergy 1987;59:90-92.

118. Lessof MH. Mechanisms of food allergy and food intolerance. Voeding 1990;51:188.

119. Lifshitz CH, Hawkins HK, Guerra C, Byrd N. Anaphylactic shock due to cow's milk protein hypersensitivity in a breast-fed infant. J Pediatr Gastroenterol Nutr 1988;7:141 144.

120. Lilja G, Danneus A, Foucard T, Graff Lonnevig V, Johansson SG, Oman H. Effect of matemal diet during late pregnancy and lactation on the development of $\operatorname{lgE}$ and egg-specific and milk- specific $\operatorname{lgE}$ and $\operatorname{IgG}$ antibodies in infants. Clin Exp Allergy 1991;21:195-202.

121. Lindberg RE, Arroyave C. Levels of IgE in serum from normal children and allergic children as measured by an enzyme immuno-assay. J Allergy Clin Immunol 1986; 78:614-618.

122. Lingham S. Food intolerance: clinical features, diagnosis and management. Br J Clin Practice 1985;39:49-53.

123. Loveless MH. Milk allergy: A survey of its incidence; Experiments with a masked ingestion test. J Allergy Clin Immunol 1950;21:489-499. 
124. Lympany P, Welsh KI, Cochrane GM, Kemeny DM, Lee TH. Genetic analysis of the linkage between chromosome IIq and atopy. Clin Exp Allergy 1992;22:1085-1092.

125. Maluenda C, Philips AD, Briddon A, Walker Smith JA. Quantitative analysis of small intestinal mucosa in cow's milk sensitive enteropathy. J Pediatr Gastroenterol Nutr 1984:3:349-356.

126. Marcucci F. Sensi LG, Bizzarri G. Specific IgE and inhalant allergens in intestinal washings of children affected by atopic eczema. Clin Allergy 1985;15:345-354.

127. Martin JM, Trind B, Daneman D, Dosch HM, Robinson R. Milk proteins in the etiology of insulin-dependant diabetes mellitus. Ann Med 1991:23 (4):447-450.

128. May DC, Bock SA. A modern clinical approach to food hypersensitivity. Allergy 1978:33:166-188.

129. McCarty EP, Frick OL. Food sensitivity: Keys to diagnosis. J Pediatr 1983;102:645652.

130. Meer vd S, Forget P. Abnormal small bowel permeability and duodenitis in recurrent abdominal pain. Arch Dis Childh 1990;65:1311-1314.

131. Metcalfe DD. Food hypersensitivity. J Allergy Clin Immunol 1984; 73:749-762.

132. De Monchy JGR. Consensus voedselovergevoeligheid. Ned Tijdschr Geneeskd 1991: 135:1538-1541.

133. Mueller HL, Weiss RJ, O'Leary D, Murray AB. The incidence of milk sensitivity and the development of allergy in infants. N Engl J Med 1963;268:1220-1224.

134. Mygind N. Essential Allergy. An illustrated text for students and specialists, 1st ed. Oxford: Blackwell Scientific Publications. 1986.

135. Noone C, Menzies IS, Banatvala JE, Scopes JW. Intestinal permeability and lactose hydrolysis in human rotaviral gastroenteritis assessed simultaneously by non-invasive differential sugar permeation. Eur J Clin Invest 1986;16:217-225.

136. Onorato J, Merland N, Terral C, Michel FB, Bousquet J. Placebo-controlled doubleblind food challenge in asthma. I Allergy Clin Immunol 1986;78:1139-1146.

137. Ortolani C, Ispano M, Pastorello E, Bigi E, Ansaloni R. The oral allergy syndrome. Ann Allergy 1988;66:47-52.

138. Pahud JJ, Schwartz K. Research and development of infant formulae with reduced allergenic properties. Ann Allergy 1984;53:609-614.

139. Patterson S, Roebuck P, Platts-Mills TAE, Shiner M, Kingston D, Pearson JR. IgE plasma cells in human jejunum demonstrated by immunoelectron microscopy. Clin Exp Immunol 1981;46:301-304.

140. Patrick MK, Grant Gall D. Protein intolerance and immunocyte and enterocyte interaction. Pediatr Clin N Am 1988;35:17-34.

141. Pearson DJ. Problems with terminology and with study design in food sensitivity. In: John Dobbing, ed. Food intolerance, Ist ed. London: Baillière Tindall 1987:1-23.

142. Pike MG, Heddle RJ, Boulton P, Turner MW, Atherton DJ. Increased intestinal permeability in atopic eczema. J Invest Dermatol 1986:86:101-104.

143. Pirquet $\mathbf{C}$ von. Allergie. Munch Med Wochenschr 1906;53:214.

144. Queille C, Saurat JG. Dermatite atopique (eczema constitutionnel). Etude informatisée de 300 observations. Joum. Parisienes Pediatr Paris: Ed Flammarion 1981:293-301.

145. Ramage JK, Stanitz A, Scicchitano R, Hunt RH, Perdue MH. Correlation of increased permeability to 5!-Cr EDTA and Ovalbumin during acute inflammation and anaphylaxis. Gastroenterology 1988;94:1368-1375.

146. Răsănen $\mathrm{L}$, Letho $\mathrm{M}$, Reunala $\mathrm{T}$. Diagnostic value of skin and laboratory test in cow's milk allergy/intolerance. Clin Exp Allergy 1992;22:385-390. 
147. Ratner D, Eshel E, Vigder K. Juvenile rheumatoid arthritis and milk allergy. J Roy Soc Med 1985;78:410-413.

148. Reddy MM, Weissman, Mazza DS, Meriny DK, Johns M, Carrabis S, Grieco MH. Circulating elevated levels of soluble CD23, interleukin-4, and CD20+CD23+lymphocytes in atopic subjects with elevated serum-IgE concentrations. Ann Allergy 1992;69:131-134.

149. Rich SS, Roitman-Johnson B, Greenberg B, Roberts S, Blumenthal MN. Genetic analysis of atopy in three large kindreds: no evidence of linkage to D1 IS97. Clin Exp Allergy 1992;22:1070-1076.

150. Richman LK, Graeff AS, Yarchoan R, Strober W. Simultaneous induction of antigenicspecific IgA helper T-cells and IgG suppressor T-cells in the murine Peyer pach after protein feeding. J Immunol 1981;126:2079-2083.

151. Rosekrans PCM, Meijer CJLM, Comelisse CJ, vd Wal AM, Lindeman J. Use of morphometry and immuno-histochemistry of small intestinal biopsy specimens in the diagnosis of food allergy. J Clin Path 1980;33:125-130.

152. Rugo E, Wahl R, Wahn U. How allergenic are hypoallergenic infant formula. Clin Exp Allergy 1992;22:635-639.

153. Ruiz RGG, Kemeny DM, Price IF. Higher risk of infantile atopic dermatitis from maternal atopy than from paternal atopy. Clin Exp Allergy 1992;22:762-766.

154. Rzany B, Jarisch R, Götz M. Spezifische IgE-Antikörper gegen KühmilcheiweiB und einzelne Kühmilchproteine bei Kindem mit verdacht auf Kühmilchallergie. Monatschr Kinderheilkd 1986;134:799-803.

155. Saavedra-Delgado AM, Metcalfe DD. Interactions between food antigens and the immune system in the pathogenesis of gastrointestinal diseases. Ann Allergy 1985; 55(5):694-702.

156. Sampson HA, Albergo R. Comparison of results of skin tests, RAST, and double-blind, placebo-controlled food challenges in children with atopic dermatitis. J Allergy Clin Immunol 1984;74:26-33.

157. Sampson HA, McCaskill CM. Food hypersensitivity in atopic dermatitis. Evaluation of 113 children. J Pediatr 1985; 107:669-674.

158. Sampson HA. The significance of food allergy in atopic dermatitis. In: Harms HK, Wahn U, eds. Food allergy in infancy and childhood. Berlin: Springer Verlag 1989:89100.

159. Sandberg Dh, Mcleod TF, Strauss J. Renal disease related to hypersensitivity to foods. In: Gerrard JW, ed. Food allergy: new perspectives, 1st ed. Springfield: Thomas CC 1980:144.

160. Sanderson IN, Boulton P, Menzies I, Smith JA. Improvement of abnormal lactulose/rhamnose permeability in active Crohn's disease of the small bowel by an elemental diet. Gut 1987;28:1073-1076.

161. Savilathi E. Immuno-histochemical study of the malabsorption syndrome with cow's milk intolerance. Gut 1973;14:491-501.

162. Savilahti E, Kuitunen M. Allergenicity of cow's milk proteins. J Pediatr 1992;suppl 121:12-20.

163. Schrander JJP, Unsalan-Hooyen RWM, Forget PP. 51-Cr EDTA intestinal permeability in children with cow's milk intolerance. J Pediatr Gastroenterol Nutr 1990; 10:189-192.

164. Schrander JJP, Forget PP, Blanco CE. Elimination/challenge tests in cow's milk protein intolerance. Pediatr Res 1990;28:675. 
165. Scott H, Brandtzaeg P. Pathogenesis of food protein intolerance. Acta Paediatr Scand 1989:Suppl 351:48-52.

166. Shiner M, Ballard J, Smith ME. The small intestinal mucosa in cow's milk allergy. Lancet 1975;I: 136-140.

167. Sigurs N, Hattevig G, Kjellman N-I M. Matemal avoidance of eggs, cow's milk and fish during lactation: the effect on allergic manifestations, skin prick tests and specific IgE antibodies in children at age of 4 years. Pediatrics 1992;89:735-739.

168. Slooff JP. Over het voorkomen van koemelkeiwitallergie in Nederland. Maandschr Kindergeneesk 1972;40:172-175.

169. Stintzing G, Zetterström R. Cow's milk allergy, incidence and pathogenetic role of early exposure to cow's milk formula. Acta Paediatr Scand 1979;68:383-387.

170. Strobel S, Ferguson S. Modulation of intestinal and systemic immune responses to a fed protein antigen in mice. Gut 1986;27:829-837.

171. Suomalainen H, Laine S, Soppi E, Isolauri E. Interferon-gamma generation is defective in healthy infants and absent in cow's milk allergy. Proceedings ESPGAN, Bruxelles 1992:58.

172. Suomalainen H, Avrilommi H, Isolauri E. Cow's milk challenge induces an immune respons to unrelated dietary antigens. Proceedings ESPGAN, Bruxelles 1992:67.

173. Tainio VM, Savilahti E. Value of immunologic tests in cow's milk allergy. Allergy 1990;45:189-196.

174. Taubman B. Parental counseling compared with elimination of cow's milk or soy milk protein for the treatment of infantile colic syndrome: a randomised trial. Pediatrics 1988;81:756-761.

175. Titus Lucretius Carus. De Rerum Naturum. 55 B.C.;4,1:637.

176. Turck D, Ythier H, Maquet D, Deveaux M, Marchandise X, Farriaux JP, Fontaine G. Intestinal permeability to 51-Cr EDTA in children with Crohn's disease and celiac disease. J Pediatr Gastroenterol Nutr 1987;6:535-537.

177. Vandenplas Y, Sacre L. Influences of neonatal serum IgE concentration, family history and diet on the incidence of cow's milk allergy. Eur J Pediatr 1986;145:493-495.

178. Vendel S. Cow's milk idiosyncrasy in infants. Acta Paediatr Scand 1948;35,Suppl 5:1-37.

179. Ventura A, Greco L. Cow's milk allergy in the first year of life: an Italian collaborative study. Acta Paediatr Scand 1988;suppl 348:3-14.

180. Verkasalo $M$, Kuitunen $P$, Savalahti E, Tilikainen A. Changing pattern of cow's milk intolerance: an analysis of the occurrence and clinical course in the 1960 s and mid1970s. Acta Paediatr Scand 1981;70:289-295.

181. Vitoria J, Sojo A, Rodriguez-Soriana J. Changing pattern of cow's milk protein intolerance. Acta Paediatr Scand 1990;79:566-567.

182. Vrecelli D, Geha R. The IgE system. Ann Allergy 1989;63:4-12.

183. Waldman T, Wochner RD, Laster L, Gordon S. Allergic gastroenteropathy. N Engl J Med 1967;276:761-769.

184. Walker WA. Antigen absorption from the small intestine and gastrointestinal disease. Pediatr Clin N Am 1975;22:731-746.

185. Walker WA. Summary and future directions. J Pediatr 1992;121 suppl:4-6.

186. Walker-Smith J. Cow's-milk protein intolerance. Transient food intolerance in infancy. Arch Dis Childh 1975;50:347-350.

187. Walther FJ, Kootstra G. Necrotizing enterocolitis as a result of cow"s-milk allergy. Z Kinderchir 1983;38(2): 110-111. 
188. Weaver LT, Laker MF, Nelson R. Enhanced intestinal permeability in pre-term babies with bloody stools. Arch Dis Childh 1984;59:280-281.

189. Weck AL. Immunologic diagnostic tests in food allergy. In: Schmidt E,ed. Food Allergy. Nestle nutrition workshop series 1989;17:177-186.

190. Wide L, Bennich H, Johansson SGO. Diagnosis of allergy by an in vitro test for allergen antibodies. Lancet 1967;II:1105-1106.

191. Wilson NM. Food-related asthma: a difference between two ethnic groups. Arch Dis Childh 1985;60:861-865.

192. Wilson N, Hamburger R. Allergy to cow's milk in the first year of life and its prevention. Ann Allergy 1988;61:323-327.

193. Wood C. How common is food allergy? Acta Paediatr Scand 1986;323 suppl:76-83.

194. Young RP, Sharp PA, Lynch JR, Faux JA, Lathrop GM, Cookson WOCM, Hopkin JM. Confirmation of genetic linkage between atopic IgE responses and chromosome $11 \mathrm{q} 13$. J Med Genet 1992;29:236-238.

195. Zeiger RS, Heller S, Mellon MH, Forsythe AB, O'Connor RD, Hamburger RN, Schatz $\mathrm{M}$. Effect of combined maternal and infant food-allergen avoidance on development of atopy in early infancy: a randomized study. J Allergy Clin Immunol 1988;84:72-89.

196. Zeller M. Rheumatoid arthritis: food allergy as a factor. Ann Allergy 1949;7:200-205. 



\section{Chapter 2}

\section{AIM OF THE STUDY}

\subsection{INTRODUCTION}

Many questions concerning CMPI remain unanswered (see Chapter 1). in the present work, we have attempted to clarify some of these unresolved questions. CMPI presents with such a clinical diversity that no agreement has been reached as far as diagnostic criteria are concerned. Due to the lack of standardized diagnostic criteria widespread differences in reported incidence rates of CMPI and in management approaches used with infants "suspected" of CMPI have been brought about. The milk elimination/challenge test is considered the best accepted diagnostic test and in a preliminary study we demonstrated that two elimination/challenge tests with cow's milk were sufficient for a correct diagnosis.

\subsection{INCIDENCE OF CMPI}

The reported incidence of CMPI shows a wide variability $(0.3 \%-10 \%)$. Our furst objective was to firmly establish the incidence rate in our regional infant population by performing a prospective epidemiological study.

\subsection{VARIOUS DIAGNOSTIC TESTS}

The reported value of various diagnostic tests for CMPI often differs from one author to the other. Several studies compare results of diagnostic tests for CMPI to healthy rather than sick control groups. Sick controls are infants with symptoms possibly due to cow's milk protein intolerance but in which CMPI and lactose intolerance are excluded. We consequently decided to analyze the diagnostic value of the following data obtained from our patients in a prospective manner. 
2.3a: The usefulness of family history, serum IgE level and RAST for the diagnosis of CMPI was examined. The prevalence of family atopy in one or both parents or siblings could be indicative for CMPI in a symptomatic child. Do elevated serum IgE levels or milk RAST improve diagnostic accuracy of CMPI when compared to family history for atopy? Results were critically compared to available literature data.

2.3b: The presence of mucosal IgE plasma cells in several children with cow's milk intolerance has been reported in two articles. The sensitivity and specificity of this finding is not known. The relationship between the presence of duodenal mucosal IgE plasma cells in infants and serum IgE level or RAST results has not been investigated. Less than $50 \%$ of infants with CMPI have a positive RAST for cow's milk. An elevated IgE level and a positive RAST indicate the presence of a generalized immunological reaction. Possibly more local or regional immunological processes are involved in CMPI, maybe restricted to the intestine.

In a prospective study, we looked for the presence of $I g E$ plasma cells in small bowel mucosa and their relationship to serum IgE levels and RAST results in children with CMPI.

2.3c: A decreased mucosal barrier integrity as measured by intestinal permeability tests could be implicated in the pathogenesis of food intolerance in children. Making use of $5 I-\mathrm{Cr}$ EDTA, as intestinal permeability marker, we focused on evaluating intestinal permeability in a group of young children clinically suspected of having cow's milk protein intolerance. No literature data were available concerning initial $51 \mathrm{Cr}$ EDTA permeability in children with CMPI.

\subsection{PROGNOSIS AND FOLLOW UP}

The reported duration of CMPI varies in the literature. According to the clinical follow-up studies symptoms of CMPI disappeared at the age of $1-3$ years. In our experience, healing occurred at a later age than reported in the literature. As a possible relationship between $\operatorname{IgE}$ and RAST and the healing rate has not been studied in detail, we wanted to examine these aspects in a prospective study. 


\section{Chapter 3}

\section{COW'S MILK PROTEIN}

INTOLERANCE IN INFANTS UNDER ONE YEAR OF AGE: A PROSPECTIVE EPIDEMIOLOGICAL STUDY

J.J.P. Schrander, J.P.H. van den Bogart, P.P. Forget, C.T.R.M. Schrander - Stumpel, R.H. Kuijten, A.D.M. Kester. 


\subsection{ABSTRACT}

Incidence and clinical manifestation of CMPI were studied in 1158 unselected newborn infants followed prospectively from birth to 1 year of age. No food changes were required in 914 infants who were used as healthy controls. When CMPI was suspected (211 infants), diagnostic dietary interventions according to a standard protocol were performed. After exclusion of lactose intolerance, two positive cow's milk elimination/challenge tests were considered diagnostic of CMPI.

Two hundred and eleven symptomatic infants were examined for possible CMPI. A large group of 80 infants improved on a lactose reduced formula. In $87 / 211$ infants CMPI was excluded (sick controls). Finally CMPI was proven in 26 infants. The calculated incidence rate for CMPI was $2.8 \%$. The principal symptoms in infants with CMPI were gastrointestinal, dermatological and respiratory in $50 \%, 31 \%$ and $19 \%$ respectively. A positive family history for atopy (first or second degree relatives) was more frequent in either CMPI infants $(65 \%)$, or sick controls (63\%) when compared to either healthy controls $(35 \%)$ or infants improving on a low lactose formula (51\%). Differences between patients with CMPI and sick controls were only found for the presence of atopy in at least two first degree rellatives (5/26 in CMPI infants and 4/87 in sick. controls) $(\mathrm{p}<0.05)$ and for multiorgan involvement $(10 / 26$ infants with CMPI as opposed to $12 / 87$ in the sick control group) ( $\mathrm{p}<0.02$ ). These statistical differences are too weak to be of clinical value.

\subsection{INTRODUCTION}

Symptoms probably caused by cow's milk protein intolerance are common in early childhood. Reported incidence rates of CMPI range from $0.3 \%$ to $7.5 \%$. $(6,10,14,28)$. These large differences can be attributed to the use of variable diagnostic criteria such as the number of milk challenges, and the various immunological tests used $(8,22,24,25,28)$. Variability in patient selection $(4,6$, $10,19,26,28)$, types of feeding regime $(14,22)$, as well as differences in study design such as retrospective evaluation in some studies $(17,22)$ and prospective in others $(10,14)$ also explain the large variations in reported incidence rates.

The first objective of this study was to establish the prevalence of CMPI in an unselected group of newborn infants.

The second objective was to look for diagnostic clues of CMPI through the study of both family history of atopic disease and our patients clinical symptoms. 


\subsection{PATIENTS AND METHODS}

The study was performed in Maastricht (The Netherlands). In order to obtain a representative cross section of all social classes, 1386 unselected infants, born between 1985 and 1988 and prospectively followed in five health care centres distributed throughout the city, were enroled in the study. A standard form was used by the four health care doctors for entering data concerning family history, symptoms and dietary interventions, if applicable. At the child health care centre weight gain and length were registered monthly. Family history regarding atopic diseases (asthma, hayfever, eczema, urticaria, allergic rhinitis) as well as possible food intolerance (reproducible adverse reaction to food) in first and second degree relatives were recorded. When present for more than 2 weeks (in most cases), the following complaints were considered suspect for the presence of CMPI: gastro-intestinal (vomiting, diarrhoea, growth failure, flatulence and crying/colic), respiratory (chronic recurrent thinitis, chronic recurrent coughing, recurrent wheezy bronchitis) and cutaneous manifestations (erythema, eczema, urticaria, angioedema). The symptoms crying/colic were considered when present for more than 2 hours.

The first dietary intervention consisted of a lactose poor infant formula (Nutrilon Laag Lactose, Nutricia, 1.3 gram lactose, normal protein content) in order to exclude lactose intolerance. If the symptoms persisted, a cow's milk free diet consisting of either Pregomin or soya milk was given. If symptoms did not resolve on soya milk, Pregomin was prescribed. Pregomin (Milupa) is a protein hydrolysate, containing proteins of animal (collagen) and vegetable (soya) origin.

Cow's milk challenges were performed 2 weeks later in infants with gastrointestinal and respiratory symptoms and 4 weeks later in most infants with cutaneous manifestations. The challenges in patients with gastro-intestinal symptoms were done with full amounts of milk. In children with an increased risk for anaphylactoid reactions the challenges were performed with increasing amounts of milk 5, 10, 30,50,100 ml. If symptoms resolved on a cow's milk free diet, infants were submitted to a cow's milk challenge test. When a relapse occurred, a second elimination/challenge test was performed. When symptoms developed in a breast fed child, milk was removed from the mother's diet. If symptoms resolved, two positive elimination/challenge tests with milk given to the mother were accepted as diagnostic of CMPI. When symptoms did not resolve the feeding regime as described above for children without breast-feeding was given to the infant. A positive challenge was defined as the recurrence of the patients original complaints, accepting some shifting in the pattern of symptoms in the very few patients in whom this occurred. Two positive elimination/challenge tests, after exclusion of lactose intolerance, were considered diagnostic for CMPI $(5,11,16)$. 
Table 1:

Prospective CMPI epidemiological survey of 1386 consecutive newborns.

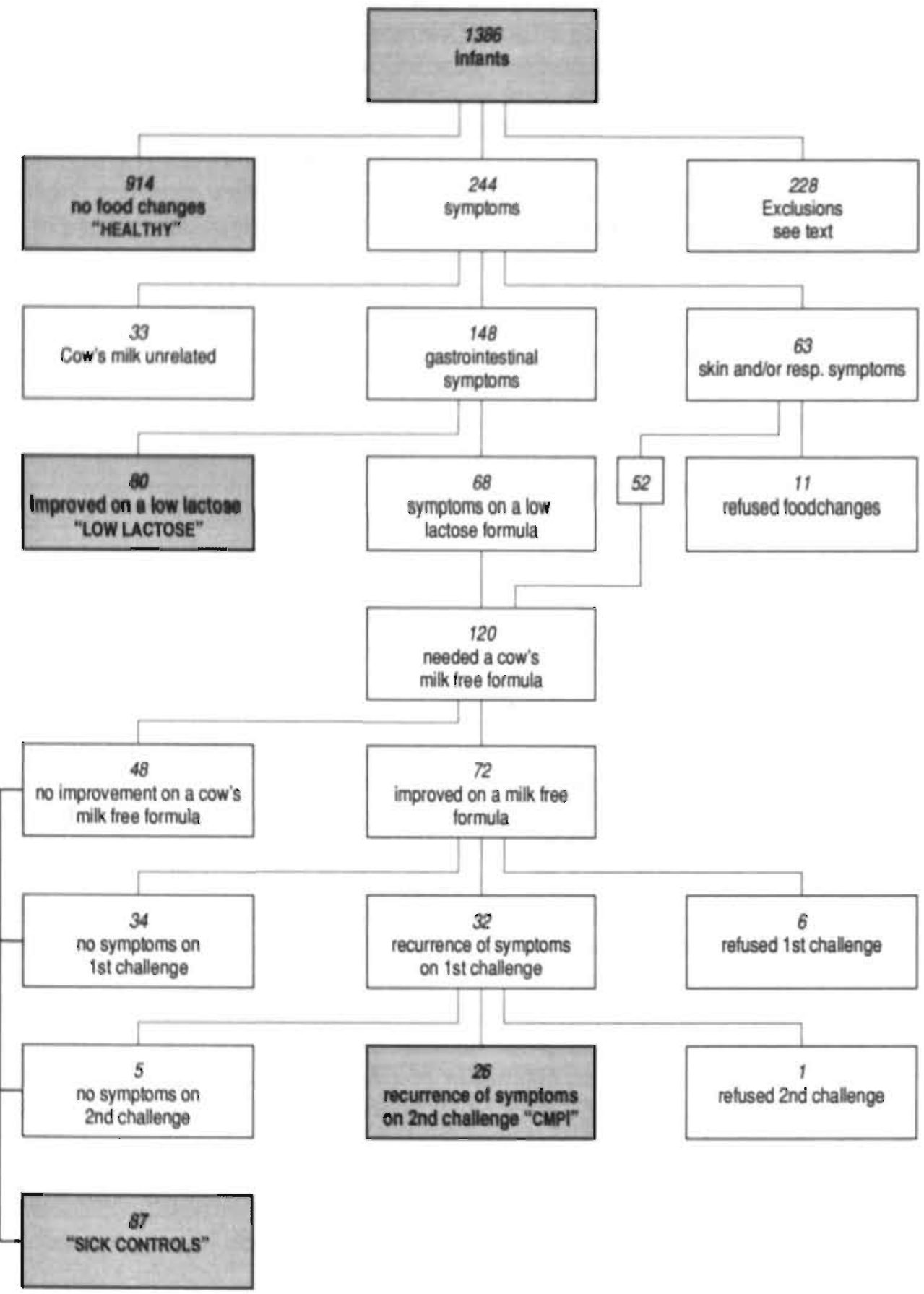


For further analysis groups were defined as "healthy" (914 infants without food changes), "low lactose" ( 80 infants improving on a lactose-free formula), "CMPI group" (26 infants with CMPI) and "sick controls" (87 patients either not improving on a cow's milk free formula or with non-recurrence of symptoms during the cow's milk challenges).

\subsubsection{Statistical analysis}

To determine the incidence rate of CMPI it was assumed that the latter was similar in compliers and non compliers. Infants relapsing at the second challenge test were considered to have CMPI. This situation is analogous to a survival study with the interesting survival rate being only that at the last timepoint. A.t each step parents could refuse further co-operation. Those who refused were considered as "censored observations". Hence the incidence rate was calculated as the value of the Kaplan-Meier estimate at the outcome of the last challenge, with the appropriate (Greenwood) standard error to obtain a confidence interval (1).

Groups of children were compared using Chi-square tests, p-values less than $5 \%$ were considered significant.

\section{Ethical approval}

The study protocol was approved by the Ethical committee of the Academical Hospital Maastricht.

\subsection{RESULTS}

Table 1 summarises the results. A total of 1386 infants were enroled, 228 infants had to be excluded, of whom 191 infants moved out of the area, while the records of 37 infants were either lost or incomplete. No differences were found between the five health care centres as far as symptoms and food changes are concerned. Of these infants 1158 were available for the study, 914 of which did not need food changes (healthy controls). Dietary interventions were needed in 244 children. Of these 244 infants 33 had dietary changes unrelated to cow's milk intolerance. Of the remaining 211 infants, 148 with mainly gastro-intestinal complaints consented to a change to a low lactose formula, which was successful in 80 infants (low lactose group). The other 68 infants with mainly gastro-intestinal symptoms and 63 infants with mainly skin and respiratory symptoms, were offered a cow's milk free diet. 


\section{Table 2:}

Frequency of symptoms in various patient groups.

\begin{tabular}{lccc}
\hline & $\begin{array}{l}\text { Low lactose } \\
\mathrm{n}=80\end{array}$ & $\begin{array}{l}\text { Sick controls } \\
\mathrm{n}=87\end{array}$ & $\begin{array}{l}\text { CMPI } \\
\mathrm{n}=26\end{array}$ \\
\hline $\begin{array}{l}\text { vomiting } \\
\text { diarrhoea }\end{array}$ & $21(26 \%)$ & $9(10 \%)$ & $3(12 \%)$ \\
growth failure & $32(40 \%)$ & $10(12 \%)$ & $7(27 \%)$ \\
flatulence & $16(20 \%)$ & $2(2 \%)$ & $4(15 \%)$ \\
crying & $20(25 \%)$ & $27(31 \%)$ & $2(8 \%)$ \\
erythema & $61(76 \%)$ & $44(51 \%)$ & $11(42 \%)$ \\
eczema & $3(4 \%)$ & $7(8 \%)$ & $2(8 \%)$ \\
urticaria & $2(3 \%)$ & $16(18 \%)$ & $9(35 \%)$ \\
& & $1(1 \%)$ & $2(8 \%)$ \\
rhinitis & & $7(8 \%)$ & $1(4 \%)$ \\
coughing & & $5(6 \%)$ & $5(19 \%)$ \\
wheezing & $2(3 \%)$ & $8(9 \%)$ & $3(12 \%)$ \\
\hline
\end{tabular}

Table 3:

Frequency of atopic disease in infants with either one and two or more first degree atopic relatives.

Patient groups only one first two or more first degree relative degree relatives

\begin{tabular}{lrrrl}
\hline Healthy conitrol & 914 & $217(24 \%)$ & $44(4.8 \%)$ & + \\
Low lactose & 80 & $22(28 \%)$ & $2(2.5 \%)$ & ++ \\
Sick control & 87 & $43(49 \%) *$ & $4(4.6 \%)$ & ++ \\
CMPI & 26 & $14(54 \%) * *$ & $5(19 \%)$ & \\
\hline
\end{tabular}

* $\quad \mathrm{p}<0.001$ (compared to the healthy control group)

** $\quad p<0.005$ (compared to the healthy control group)

$+\quad p<0.005$ (compared to the CMPI group)

$+\quad p<0.02$ (compared to the CMPI group)

$++\quad p<0.05$ (compared to the CMPI group) 
The parents of 11 infants refused food changes (all respiratory and skin symptoms). The cow's milk free diet was successful in 72 of the 120 compliers. The first cow's milk challenge was refused by 6 and resulted in relapsing symptoms in 32 . Of these, 31 accepted a second challenge, which was again positive in 26 . These $26 / 1158(2.3 \%)$ infants were considered to have CMPI. Out of $26,13(50 \%)$ responded to cow's milk within $3 \mathrm{~h}$ after milk ingestion. Out of 26 CMPI 20 infants were followed for four years, $6(23 \%)$ still had symptoms due to cow's milk. Eighteen infants did not follow the study protocol, but were retained in the analysis as far as possible. Using the Kaplan-Meier estimate the incidence rate of CMPI was calculated to be $2.8 \%$ with a confidence interval of $1.8 \%$ to $3.8 \%$. The sick control group consisted of three subgroups of 87 patients in total, who either did not improve on a cow's milk free diet or did not relapse on challenge tests. The latter three subgroups showed no differences as far as family history, age of onset and symptoms are concerned.

No difference existed in the mean age of onset of symptoms, 9 weeks (range 1 - 52 weeks), 16 weeks (range 3 - 51 weeks) and 13 weeks (range 2 - 48 weeks) in the low lactose-, sick control- and CMPI group respectively. After a period of 6 months all low lactose group infants tolerated lactose clinically. A detailed description of symptoms is given in Table 2. If symptoms are considered as clusters, the frequencies of respiratory, gastrointestinal and dermatological symptoms were similar in CMPI patients and in sick controls.

Multi-organ involvement (symptoms in two or more organ systems) was significantly more frequent in the CMPI group $(10 / 26,39 \%)$ when compared to the sick controls $(12 / 87,14 \%)(p<0.01)$. Sixty five infants had crying as main symptom; $4(6 \%)$ of them were intolerant to cow's milk protein.

A summary of our data concerning the family history for atopy is shown in table 3. A positive family history for atopy in at least two first degree relatives was found in $19 \%$ in the CMPI group against a maximum of $4.8 \%$ in the other groups ( $p<0.05$ ). We found an incidence of CMPI in $12 \%$ of first - and second degree relatives of CMPI infants, against $1.3 \%$ in the sick controls $(p<0.007)$.

\subsection{DISCUSSION}

\subsubsection{Incidence}

In the present study the incidence of CMPI was $2.8 \%, 50 \%$ had a reaction to cow's milk reintroduction within $3 \mathrm{~h}$. The incidence rate was calculated under the assumption that non compliance is unrelated to CMPI. If such an assumption is not made, one can only determine upper and lower limits for the estimated incidence rate. The first by assuming that all non-compliers have CMPI; this would mean an incidence of $44 / 1158=3.8 \%$. Assuming all non-compliers to be 
free of CMPI gives an estimate of $26 / 1158=2.3 \%$. The reported incidence of CMPI in infants varies from $0.3 \%-10 \%(6,10,28)$. Several factors can account for this large variation.

First, considerable variation exists in the composition of the patient groups. Clein (5), Collins-Williams (6), Vitoria et al (26) and Bachman and Dees (2) reported data concerning a private practice population. The infants in our study were seen at health care centres, where $99 \%$ of Dutch infants are followed.

Second, diagnostic criteria vary considerably. The original Goldman's diagnostic criteria (11) for CMPI consisted of three positive elimination/challenge tests which are very difficult to fulfil. Several authors $(8,24,25)$ accept less than two positive cow's milk elimination/challenge tests for the diagnosis of CMPI and therefore most of them report a higher incidence of CMPI. Stintzing and Zetterstrom (22) accepted positive challenges only when symptoms occurred within $48 \mathrm{~h}$ of a milk challenge, while Bishop et al (4) also took symptoms arising 1 week post challenge into account. While some authors accept " colic" as a symptom of CMPI, others do not (10). These factors make the large variations in reported incidence of CMPI understandable.

\subsubsection{Lactose intolerance}

Lactose intolerance may mimick the symptoms of CMPI $(14,15)$ and may lead to a high figure for the incidence of CMPI if it is not excluded first, especially in infants with persisting diarrhoea (27) or infantile colic (15). Of the 211 infants with symptoms suggestive of CMPI not less then 80 infants showed a good response to a low lactose feeding (low lactose group). No mention is made of such a finding in previous studies. In keeping with our protocol neither lactose elimination/challenge tests nor routine laboratory tests for the diagnosis of lactose intolerance were performed, so it is impossible to evaluate accurately the role played by lactose intolerance in our patients. Lactose challenge was performed in only 27/80 infants and 16 of them showed a relapse. Most of our babies improving on a lactose reduced formula had colic as one of their main symptoms, but a majority of studies do not support a role for lactose intolerance in infantile colic $(3,15,18,21,23)$. Further studies are needed in order to elucidate this unexpected finding.

\subsubsection{Food changes}

Apart from the work of Gerrard et al (10) no study involved so many infants who needed food changes as the present one. Of the total group of infants $17 \%$ had a formula change, whereas $10.2 \%$ received a cow's milk free diet. Such dietary changes were needed in only $4 \%$ and $5 \%$ in Jakobson and Lindberg (14) and Douwes et al (8) studies respectively. 


\subsubsection{Symptoms}

In agreement with literature data $(10,14)$ gastro-intestinal symptoms were the most frequent complaints in infants with CMPI and occurred in $50 \%$ of them. Bachman and Dees (2) reported dermatological problems as the most frequent complaint $(70 \%)$, however their patients were selected on the basis of atopy. Multiorgan involvement was significantly more frequent in infants with CMPI when compared to sick controls. These data can be of use for the diagnostic workup of these infants.

\subsubsection{Infantile colic}

Infantile colic are characterized by bouts of excessive prolonged crying for 2 $3 \mathrm{~h}$ or more $(8,11,13,16)$. In our study, colic/crying occurred in $42 \%$ of the infants with CMPI. The occurrence of colic in CMPI patients was reported in $20 \%, 28 \%, 31 \%$ and $35 \%$ in the studies of Gerrard et al (10), Goldman et al (11), Clein (5) and Jakobsson and Lindberg respectively (14), In our study 65 infants had crying as cardinal symptom, CMPI was confirmed in $4(6 \%)$ of them. Looking at our figures CMPI is a rare cause of infantile colic. This might explain why Taubman (23) had more success with parental counselling than with cow's milk removal in infants with colic/crying.

\subsubsection{Age of onset}

The age of onset of CMPI is comparable to that reported by others. No significant differences were found when comparing the three patient groups of the present study as far as the age of onset is concerned.

\subsubsection{Family history}

Atopy (the allergic responsiveness to one or more common antigens) can occur in a family as an autosomal dominant trait (7); environmental factors contribute to the clinical expression. Without a clear autosomal dominant pedigree, a multifactorial aetiology of atopy is assumed and empirical risk figures can be used (9). The present study gives such figures for infants less then 1 year of age. In our study we found an incidence of CMPI of $4 \%$ in infants with one first degree atopic relative against an incidence of $1.5 \%$ in infants without such a history. For two first degree atopic relatives the figures are still low: $9 \%$ against $2 \%$. In our study familial atopy represents a risk factor but it does not appear to be a very critical one. The incidence of atopic diseases in the family of infants with CMPI was significantly increased when compared to our healthy control and low lactose group, while this was not the case for the sick control group. The 
only difference in family history for atopy between CMPI infants and the sick control infants was for the presence of at least two first degree atopic relatives. Several studies also find clear differences between infants with CMPI and healthy controls $(5,12,14)$. However, comparisons with a sick control group such as ours have not been reported. For practical purposes such a comparison should be made.

Ventura and Greco (24) reported an incidence of $10.8 \%$ of CMPI in family members of CMPI infants, against $2.6 \%$ in a control group. This is in keeping with our results showing an incidence of $12 \%$ in family members of CMPI infants and $1.3 \%$ in the healthy control group.

\subsubsection{Followup}

Out of 26 infants 20 were followed for 4 years. At 4 years of age $77 \%$ of our study group was tolerant to cow's milk. The percentage in the study of Bishop et al (4) is 19\% lower than the results of our study at the age of 4 years. A study of infants in our outpatient department showed a recovery rate of $67 \%$ at 4 years of age (20).

\subsection{CONCLUSION}

The calculated incidence rate for CMPI in an unselected population of infants was $2.8 \%$. Family history and symptoms of disease are very similar in sick controls and infants with CMPI. According to our data only the presence of a positive family history for atopy in at least two first degree relatives and the presence of multiorgan involvernent are associated with CMPI. These associations are however too weak to be of much clinical utitility.

\section{Acknowledgments}

The hypo-allergenic product Pregomin was kindly provided by Milupa. 


\section{REFERENCES}

1. Armitrage P, Berry G. Statistical methods in medical research; 2nd ed. Oxford: Blackwell 1987.

2. Bachman KD, Dees SC. Milk allergy. Observations on incidence and symptoms of allergy to milk in allergic infants. Pediatrics 1957;32:400-407.

3. Barr RG, Clogg LJ, Wooldridge JA, Tansey CN. Carbohydrate intolerance has no effect on infant crying behaviour: A randomized controlled trial. AJDC 1987; 141:391.

4. Bishop JM, Hill DJ, Hosking CS. Natural history of cow milk allergy: clinical outcome. J Pediatr 1990;116:862-867.

5. Clein N. Cow's milk allergy in infants and children. Int Arch Allergy 1958;13:245-256.

6. Collins Williams $\mathbf{C}$. The incidence of milk allergy in pediatric practice, J Pediatr 1956;48:39-47.

7. Cookson WOCM, Hopkin JM. Dominant inheritance of atopic immunoglobulin-E responsiveness. Lancet 1989;1:86-88.

8. Douwes AC, Weert-Waltman ML van, Folkertsma K, Fagel JFM, Verboom WSW. Prevalence of foodallergy in Amsterdam infants. Ned Tijdschr Geneesk 1988;132: 1392-1396.

9. Emery AEH, Rimoin DL. Principles and practice of medical genetics, 2nd ed. Edinburgh: Churchill Livingstone 1990.

10. Gerrard JW, MacKenzie JWA, Goluboff N, Garson JZ, Maningas CS. Cow's milk allergy: prevalence and manifestations in an unselected series of newboms. Acta Paediatr Scand 1973;234 suppl:1-21.

11. Goldman A, Anderson DW, Sellers WA, Saperstein S, Kniker WT, Halpem SR. Milk allergy: I Oral challenge with milk and isolated milk proteins in allergic children. Pediatrics 1963;32:425-443.

12. Halpem SR, Sellars WA, Johnson RB, Anderson DW, Saperstein S, Reisch JS. Development of childhood allergy in infants fed breast, soy or cow milk. J Allergy Clin Immunol 1973;51:139-151.

13. Illingworth RS. Infantile colic revisited. Arch Dis Childh 1985;60:981-985.

14. Jakobsson I, Lindberg T. A prospective study of cow's milk intolerance in Swedish infants. Acta Paediatr Scand 1979;68:853-859.

15. Liebman W. Infantile colic association with lactose and milk intolerance. JAMA 1981;245:732-733.

16. Lothe $L$, Lindberg $T$. Cow's milk whey protein elicts symptoms of infantile colic in colicky formula fed infants: A double blind crossover study. Pediatrics 1989;83:262266.

17. Loveless MH. Milk allergy: A survey of its incidence; Experiments with a masked ingestion test. J Allergy Clin Immunol 1950;21:489-499.

18. Moore DJ, Robb TA, Davidson GP. Breath hydrogen response to milk containing lactose in colicky and non colicky infants. J Pediatr 1988;1 13:979-984.

19. Mueller HL, Weiss RJ, O'Leary D, Murray AB. The incidence of milksensitivity and the development of allergy in infants. N Engl J Medicine 1963;268:1220-1224.

20. Schrander JJP, Oudsen S, Forget PP, Kuijten RH. Follow up study of cow's milk protein intolerant infants. Eur J Pediatr 1992;151:783-785.

21. Stahlberg MR, Savilathi E. Infantile colic and infant feeding. Arch Dis Childh 1986; 61:1232-1233. 
22. Stintzing G, Zetterström R. Cow's milk allergy, incidence and pathogenetic role of early exposure to cow's milk formula. Acta Paediatr Scand 1979;68:383-387.

23. Taubman B. Parenteral counseling compared with elimination of cow's milk or soy milk protein for the treatment of infantile colic syndrome: A randomized trial. Pediatrics 1988;81:756-761.

24. Ventura A, Greco L. Cow's milk allergy in the first year of life: an Italian collaborative study. Acta Paediatr Scand 1988;348 suppl:3-14.

25. Verkasalo M, Kuitunen P, Savalahti E, Tilikainen A. Changing pattern of cow's milk intolerance: an analysis of the occurrence and clinical course in the $60 \mathrm{~s}$ and mid-70s. Acta Paediatr Scand 1981;70:289-295.

26. Vitoria J, Sojo A, Rodriguez-Soriana J. Changing pattem of cow's milk protein intolerance. Acta Paediatr Scand 1990;79:566-567.

27. Wilson NW, Hamburger RN. Allergy to cow's milk in the first year of life and its prevention. Ann Allergy 1988;61:323-327.

28. Wood C. How common is food allergy. Acta Paediatr Scand 1986;323 suppl:76-83. 


\section{Chapter 4}

\section{DIAGNOSTIC VALUE OF FAMILY HISTORY, TOTAL IGE AND COW'S MILK RAST IN INFANTS WITH COW'S MILK PROTEIN INTOLERANCE}

J.J.P. Schrander, S. Oudsen, P.P. Forget, R.H. Kuijten, C.T.R.M. Schrander-Stumpel, A.D.M. Kester, P.C.A. Menheere. 


\subsection{ABSTRACT}

To evaluate the usefulness of family history, serum IgE level and RAST for the diagnosis of cow's milk protein intolerance (CMPI), 218 consecutive infants from our outpatient clinic who presented complaints suggestive of CMPI were enroled in a prospective study. The likelihood ratio method was used for the evaluation of the above mentioned diagnostic test procedures. Based on two positive cow's milk elimination/challenge tests and exclusion of lactose intolerance, 104 infants proved to have CMPI, while this diagnosis was rejected in the other 114 infants (sick control group).

A family history of atopy among two first-degree relatives was present in $21 / 104$ CMPI patients and in 6/114 sick controls $(p<0.02)$. The calculated likelihood ratio was 3.8 .

$61 / 104$ infants with CMPI and 43/114 without had a serum $\mathrm{IgE}$ level $>10 \mathrm{k}$ $\mathrm{kU} / \mathrm{l}(\mathrm{p}<.003)$. The low posterior probability $(59 \%)$ and likelihood ratio (1.6) points to the low diagnostic usefulness of serum IgE levels.

The RAST for cow's milk was positive in 38/104 infants with CMPI and in $11 / 114$ sick controls ( $\mathrm{p}<0.0001$ ). The posterior probability was $78 \%$. A positive test result increased the odds of CMPI by a factor of 3.8 (likelihood ratio).

$\mathrm{IgE}$ level and RAST did not improve diagnostic accuracy in patients with a positive family history of atopy in two first-degree relatives. The RAST result can be useful when the prevalence of CMPI in an outpatient clinic is high, in the presence of either a negative family history or a history of atopy in one first-degree relative, raising the odds for CMPI by a factor of 3 and 4.6 respectively.

\subsection{INTRODUCTION}

Since 1966, the term allergy has been used mostly to describe IgE-mediated hypersensitivity reactions $(15,26)$. It is still not known how many hypersensitivity reactions to cow's milk proteins are immunologically mediated. For any adverse reaction to cow's milk proteins giving symptoms of the gastrointestinal tract, skin or respiratory tract, the term cow's milk protein intolerance (CMPI) has, been used (18).

The diagnosis of CMPI is based on elimination/challenge tests. Several authors advise using two subsequent positive challenges as diagnostic criteria $(12,18)$. However, since elimination/challenge tests are time-consuming and not without risk, less cumbersome tests for the diagnosis of CMPI have been sought.

Skin prick testing (SPT) has given variable results with, according to Hoffman and Haddad (17), more positive results than can be justified by history and provocation tests. Sampson and Albergo (26) and. Queille and Saurat (22) did 
not observe much difference between RAST and SPT results for CMPI. Chau et al (5) showed better results of SPT. Several investigators have suggested that RAST and family history are valuable for the diagnosis CMPI $(26,30,31)$. These data are easy to obtain. The aim of the present study was to evaluate the usefulness of these criteria in a large prospective study of infants having symptoms suggestive of CMPI.

Results of most studies have been reported in terms of sensitivity and specificity for the various tests. For the clinician, however, predictive values are preferable as they have more impact on patient management. As predictive values cannot be extrapolated from one population to another, we have chosen the likelihood ratio method as an alternative way to present our results.

\subsection{MATERIAL AND METHODS}

\subsubsection{Patients}

218 consecutive children at the outpatient department, all less than one year of age and displaying symptoms possibly due to CMPI, were enroled in a threeyear prospective study. The symptoms were either gastrointestinal (colics, diarrhoea and vomiting), respiratory (chronic recurrent rhinitis, bronchitis, wheezy bronchitis), cutaneous (eczema, exanthema, urticaria, angioedema) or general (failure to thrive and crying). The symptoms were present for more than two weeks. Organic diseases such as pyloric stenosis, infectious diseases or cystic fibrosis were excluded.

A lactose-poor diet was first given in order to exclude lactose intolerance. If symptoms did not resolve, the protein hydrolysate Pregomin (a protein hydrolysate, containing proteins of animal (collagen) and vegetable (soy) origin (Milupa)) was given. A positive challenge was defined as the recurrence of the patient's former complaints. The challenges were done with full amounts of cow's milk. Two positive elimination/challenge tests were considered diagnostic for CMPI. When CMPI was excluded, the infants were called sick controls. Results were compared between infants with CMPI and sick controls.

Anamnestic data were obtained regarding a history of atopy (asthma, hay fever, eczema, urticaria, allergic rhinitis) in the infant's first-degree relatives. The data were obtained when babies were first included in the study, at a moment when no diagnosis had yet been made. 


\subsubsection{Laboratory investigations}

Serum IgE concentrations were assessed by means of a commercially available immuno-radiometric assay (Pharmacia IgE RIACT, Uppsala, Sweden) The RAST was done using radio-immuno-sorbent test (Phadebas Rast, Pharmacia). A RAST score of 1 or higher for one of the three discs has been accepted as positive. The measurement of IgE and RAST was performed during the first period of cow's milk elimination and reintroduction.

\subsubsection{Statistical analysis}

For each result (family history, IgE and RAST), the numbers of children with and without CMPI are given. The proportion of children with CMPI for each test outcome approximates the predictive value (posterior probability) of that test resuit. This should be compared with the prior probability, which is the prevalence or pre-test proportion of CMPI.

The likelihood ratio expresses the probability that a given level of a diagnostic test result would be found in a patient with the target disorder, as opposed to one without (24). The likelihood ratio for a positive test is calculated as sensitivity/(1 - specificity) and that of a negative test as ( 1 - sensitivity/specificity). Multiplication of the pre-test odds of disease by the likelihood ratio for the obtained test result yields the post-test odds of disease. When the disease prevalence in one's own centre is known, this can be converted to "odds" by recalling that odds = probability/ (1 - probability). Subsequent multiplication of pre-test odds by the likelihood ratio yields the post-test odds for the disease, which can be converted to the post-test probability for a given centre probability $=$ odds/ $(1+$ odds $)$.

For the family history, which has 3 possible outcomes, the likelihood ratio for the outcome "2" was calculated relative to 0 and 1 atopic first-degree relative, whereas the outcome " 1 " was contrasted with " 0 " only. 95\% confidence intervals for the likelihood ratio were determined by normal approximation. Statistical significance of the RAST, IgE and family atopy was assessed by chi-square tests, p-values smaller than $5 \%$ being considered significant.

\subsection{RESULTS}

104 out of 218 infants proved to have CMPI based on two positive elimination/challenge tests, while the diagnosis could be excluded in the other 114 infants (sick controls). Consequently the pre-test probability of having CMPI was $104 / 218=48 \%$ and the pre-test odds were $.48 / .52=.92$ 
Table 1:

Diagnostic value of different test for the diagnosis CMPI

\begin{tabular}{|c|c|c|c|c|c|c|c|}
\hline \multirow{2}{*}{$\begin{array}{l}\text { Diagnostic } \\
\text { test/history }\end{array}$} & \multicolumn{2}{|c|}{ CMPI } & \multirow{2}{*}{$\begin{array}{l}\text { Pre-test } \\
\text { prob. }\end{array}$} & \multirow[t]{2}{*}{ LR } & \multirow{2}{*}{$\begin{array}{l}\text { Confidence } \\
\text { interval }\end{array}$} & \multirow{2}{*}{$\begin{array}{l}\text { Post. } \\
\text { prob. }\end{array}$} & \multirow[t]{2}{*}{ Sign. } \\
\hline & yes & no & & & & & \\
\hline \multicolumn{8}{|l|}{ Family history } \\
\hline - two positive & 21 & 6 & $48 \%$ & 3.84 & $1.61-9.14$ & $78 \%$ & $\mathrm{p}<0.02$ \\
\hline - one positive & 36. & 37 & $44 \%$ & 1.27 & $0.88-1.81$ & $49 \%$ & \\
\hline - negative & 47 & 71 & $48 \%$ & 0.73 & $0.56-0.94$ & $40 \%$ & \\
\hline $\mathrm{IgE} \geq 10 \mathrm{kU} /$ & 61 & 43 & $48 \%$ & 1.56 & $1.17-2.07$ & $59 \%$ & $p<0.003$ \\
\hline $\mathrm{IgE}<10 \mathrm{kU} / \mathrm{n}$ & 43 & 71 & $48 \%$ & 0.66 & $0.50-0.87$ & $38 \%$ & \\
\hline RAST positive & 38 & 11 & $48 \%$ & 3.79 & $2.05-7.01$ & $78 \%$ & $\mathrm{p}<0.0001$ \\
\hline RAST negative & 66 & 103 & $48 \%$ & 0.70 & $0.60-0.82$ & $39 \%$ & \\
\hline
\end{tabular}

The LR for one atopic first degree relative was calculated relative to no atopic first degree relatives.

Abbreviation: Pre-test prob. $=$ Pre-test probability, $\mathrm{LR}=$ Likelihood ratio, Post. prob. $=$ Posterior probability, Sign. = Significance.

Table 2:

Diagnostic value of $\mathrm{IgE}$ given the family history

\begin{tabular}{|c|c|c|c|c|c|c|c|c|}
\hline \multirow{2}{*}{$\begin{array}{l}\text { Family } \\
\text { history }\end{array}$} & \multirow[t]{2}{*}{$\operatorname{IgE}$} & \multicolumn{2}{|c|}{ CMPI } & \multirow{2}{*}{$\begin{array}{l}\text { Pre-test } \\
\text { prob. }\end{array}$} & \multirow[t]{2}{*}{ LR } & \multirow{2}{*}{$\begin{array}{l}\text { Confidence } \\
\text { interval }\end{array}$} & \multirow{2}{*}{$\begin{array}{l}\text { Post. } \\
\text { prob. }\end{array}$} & \multirow[t]{2}{*}{ Sign. } \\
\hline & & yes & no & & & & & \\
\hline \multirow[t]{2}{*}{ Two positive } & $\geq 10 \mathrm{kU} / \mathrm{l}$ & 14 & 4 & $78 \%$ & 1.00 & $0.53-1.89$ & $78 \%$ & n.s. \\
\hline & $<10 \mathrm{kU} / 1$ & 7 & 2 & $78 \%$ & 1.00 & $0.28-3.61$ & $78 \%$ & \\
\hline \multirow[t]{2}{*}{ One positive } & $\geq 10 \mathrm{kU} / \mathrm{h}$ & 24 & 19 & $49 \%$ & 1.29 & $0.88-1.92$ & $56 \%$ & n.s. \\
\hline & $<10 \mathrm{kU} / 1$ & 12 & 18 & $49 \%$ & 0.64 & $0.39-1.21$ & $39 \%$ & \\
\hline \multirow[t]{2}{*}{ Negative } & $\geq 10 \mathrm{kU} / 1$ & 23 & 20 & $40 \%$ & 1.74 & $1.08-2.79$ & $54 \%$ & $p<0.04$ \\
\hline & $<10 \mathrm{kU} / \mathrm{l}$ & 24 & 51 & $40 \%$ & 0.71 & $0.52-0.98$ & $32 \%$ & \\
\hline
\end{tabular}

Abbreviation: Pre-test prob. $=$ Pretest probability, LR $=$ Likelihood ratio, Post. prob. = Posterior probability, Sign. = Signiticance. 
Table 3:

Diagnostic value of RAST given the family history

\begin{tabular}{|c|c|c|c|c|c|c|c|c|}
\hline \multirow{2}{*}{$\begin{array}{l}\text { Family } \\
\text { history }\end{array}$} & \multirow[t]{2}{*}{ RAST } & \multicolumn{2}{|c|}{ CMPI } & \multirow{2}{*}{$\begin{array}{l}\text { Pre-test } \\
\text { prob. }\end{array}$} & \multirow[t]{2}{*}{ LR } & \multirow{2}{*}{$\begin{array}{l}\text { Conf. } \\
\text { interval }\end{array}$} & \multirow{2}{*}{$\begin{array}{l}\text { Post. } \\
\text { prob. }\end{array}$} & \multirow[t]{2}{*}{ Sign. } \\
\hline & & yes & no & & & & & \\
\hline \multirow[t]{2}{*}{ Two positive } & positive & 8 & 1 & $78 \%$ & 2.29 & $0.35-14.84$ & $89 \%$ & n.s \\
\hline & negative & 13 & 5 & $78 \%$ & 0.74 & $0.46-1.21$ & $72 \%$ & n.s \\
\hline \multirow[t]{2}{*}{ One positive } & positive & 18 & 4 & $49 \%$ & 4.63 & $0.73-12.34$ & $82 \%$ & $p<0.001$ \\
\hline & negative & 18 & 33 & $49 \%$ & 0.56 & $0.39-0.79$ & $35 \%$ & \\
\hline \multirow[t]{2}{*}{ Negative } & positive & 12 & 6 & $40 \%$ & 3.02 & $1.22-7.49$ & $67 \%$ & $\mathrm{p}<0.03$ \\
\hline & negative & 35 & 65 & $40 \%$ & 0.81 & $0.68-0.98$ & $35 \%$ & \\
\hline
\end{tabular}

Abbreviation: Pre-test prob. $=$ Pre-test probability, $\mathrm{LR}=$ Likelihood ratio, Conf. interval $=$ Confidence interval, Post. prob. = Posterior probability, Sign. = Significance.

The family history was positive in two or more first-degree relatives in 21 infants with CMPI and in 6 sick controls, resulting in a posterior probability of $78 \%$ and post-test odds of 3.5 .

One first-degree relative positive for atopy (36 CMPI infants and 37 sick controls) resulted in a posterior probability of $49 \%$ (post-test odds: 0.97 ). The posterior probability for a negative family history for atopy (47 CMPI infants and 71 sick controls) was $40 \%$ (post-test odds: 0.66 )

The post-test odds for a positive IgE level and RAST results were 1.42 and 3.46 respectively. Furthermore, we looked at the IgE levels and RAST results from the point of view of family history of atopy. The post-test odds for a positive IgE level and a family history of atopy in $0,1,2$ or more first-degree relatives were $1.15,1.26$ and 3.5 respectively. The post-test odds for positive RAST results and a family history of atopy involving $0,1,2$ or more first-degree relatives were $2.0,4.5$ and 8.0 respectively.

Detailed results are shown in Tables $1-3$.

\subsection{DISCUSSION}

\subsubsection{Family history}

In the present stucly, a single atopic first-degree relative (as criterion for a positive family history) did not distinguish CMPI patients from non-CMPI patients (posterior probability 49\%). This is in contrast to Gerrard et al (12), who 
found a significant difference in family history between sick controls and CMPI patients when considering allergic mothers or siblings (not fathers). We could not confirm this finding. However, taking two atopic first-degree relatives as the criterion, the family history was more frequently positive in CMPI infants than in non-CMPI infants. The posterior probability for the latter criterion was $78 \%$. When compared to pre-test probability, such a positive family history resulted in raising the odds for CMPI by a factor 3.8. The predictive value of family history in respect of the development of allergic diseases has been the object of several reports $(12,18,20,30,31)$. Much of the variation in literature data is probably due to the various criteria used for the definition of "positive family history for atopy". Another difficult point is that one does not know what type of allergy in the family history predisposes the individual to develop CMPI. Most studies $(11,20,31)$ made use of a healthy control group and found a significant difference in family history. The comparison we made using an unselected cohort of infants with symptoms indicative for CMPI is more relevant for pediatric practice.

\subsubsection{IgE}

The use of total serum IgE in order to differentiate between allergic and non-allergic infants was established by Lindberg and Arroyave (21). Age-rclated values have been reported by the authors. Making use of a cut value of 10 $\mathrm{kU} / \mathrm{l}$, serum IgE values were more frequently elevated in CMPI infants when compared to control infants $(p<0.003)$. Vandenplas and Sacre $(30)$ found a still higher frequency of CMPI in infants with a high serum total IgE compared to those with a low serum IgE. Because of the low predictive value $(59 \%)$ and marginally increased post-test odds of 1.4 , our results indicate that total serum $\mathrm{IgE}$ is not very useful as a primary diagnostic tool. The same conclusion was reached by other authors $(9,15)$.

As the reliability of the RAST decreases when serum IgE levels are high $(17,27)$, serum IgE levels could be helpful for the interpretation of RAST results. In a previous study concerning the follow-up of infants with CMPI, we showed serum $\mathrm{IgE}$ level above $10 \mathrm{kU} / \mathrm{l}$ to be associated with slow recovery from CMPI (28).

\subsubsection{RAST for cow's milk}

Our results indicated that RAST results have limited value for the diagnosis of CMPI. $37 \%$ of infants with CMPI as opposed to $11 \%$ of sick control infants had a positive RAST. Similar results were reported by Rzany (23). The predictive value in our study was $78 \%$ (likelihood ratio 3.8 ). The difference was highly significant $(p<0.0001)$. Negative RAST results, on the contrary, had a low 
predictive value of $39 \%$ (likelihood ratio 0.7 ). RAST class 1 or higher was accepted as positive in our study. IgE antibody levels have been reported to be low in healthy children and did rarely reach RAST class 1 (13). Weck (32) reported a $3.5 \%$ occurrence of a positive cow's milk RAST in a normal infant population. Low levels of IgE antibodies in infants were often transient (19). In infancy, low titres of $\mathrm{IgE}$ antibodies to food are able to produce anaphylactic reactions while, on the other hand, high titres can be consistent with tolerance (7), making results difficult to interpret.

Sensitivity and specificity of the RAST differ greatly between authors. Sensitivity for cow's milk RAST varied from $44 \%-88 \%$ and specificity from $35 \%$ $-95 \%(20,25,28,29,31)$. The heterogeneous clinical and immunological findings in studies of infants with CMPI could be due to patient selection.

Some investigators found a good correlation between RAST and clinical diagnosis $(3,14,16,17,23)$, while others did not $(1,5,9)$. David concluded that RAST and skin testing were of little use in the diagnostic work up of food intolerance and their use was only justifiable as a research tool (8).

The sensitivity of the RAST for CMPI in our group was only $37 \%$. In a selected patient group with atopic dermatitis, Sampson and Albergo (26) found a higher RAST sensitivity of $60 \%$ and a specificity of $77 \%$. Benincori et al (3) stated that RAST might be a valuable tool when severe reactions following ingestion of food were suspected and dangerous challenge tests had to be avoided. The clinical significance of a positive milk RAST has been reported to be highest in children $0-2$ years of age (6). All infants in our study were less than one year of age. In conclusion: The RAST for cow's milk had only limited value for the diagnosis CMPI. Patients with challenge proven CMPI had no detectable $\operatorname{lgE}$ to cow's milk proteins and several atopic patients had specific cow's milk $\operatorname{lgE}$ antibodies while they fully tolerated milk $(8,10,33)$.

\subsubsection{Likelihood ratios}

To facilitate the application of our results in other centres where prevalences may be different, we have given likelihood ratios for all test outcomes (17). As an example, assume that the prevalence of CMPI is $20 \%$ instead of our figure $48 \%$. The pre-test odds are $0.2 / 0.8=0.25$. Consequently, the post-test odds for a positive RAST are $0.25 \times 3.79=0.95$ (Table 1). The posterior probability equals $0.95 /(1+0.95)=0.49(49 \%)$. The value of the cow's milk RAST decreases dramatically with a decrease in the prevalence of CMPI. Except in specialized outpatient clinics, the use of this test is debatable. 


\subsubsection{Combination of tests}

We looked at combinations of different diagnostic tools, family history for atopy, IgE level and RAST results. This combination only marginally improved the predictive value. No extra information was found of $\operatorname{IgE}$ level (similarly to results reported by Vandenplas and Sacre (30)) and of RAST results in cases of children with a history for atopy in two or more first-degree relatives. When the family history for atopy was negative or positive for only one first-degree relative, the RAST results gave additional information by raising or lowering the chance of having CMPI.

We conclude that the tests do not give additional information in respect of infants with two or more first-degree atopic relatives. The RAST can be useful in cases of infants with less than two first-degree atopic relatives in outpatient clinics with a high prevalence of CMPI.

\section{Acknowledgements}

This study was supported by Milupa, which also kindly provided the hypoallergenic feeding Pregomin. 


\section{REFERENCES}

1. Aas K: The diagnosis of hypersensitivity to ingested foods. Clin Allergy 1978;8:39-50.

2. Basayau JP, Mallet E, Brunelle P, de Menibus CH. Les intolerances au lait de vache. Etude des immunoglobulines E specifiques. Presse Med 1983;12:2041-2043.

3. Benincori N, Novarino D, Cantani A, Di Cicco C, Mwessina E, Perlini R, Buscinco LL. On the reliability of RAST in childhood food allergy. Allergol Immunopathol 1983; II,4:255-260.

4. Bjorksten B, Ahlstedt S, Bjorksten F, Carlsson B, Fallstrom SP, Juntunen K, Kajosaari D. Kober A. Immunoglobulin E and immunoglobulin G4 antibodies to cow's milk in children with cow's milk allergy. Allergy 1983;38:119-124.

5. Chau YY, Bremner K, Llobet JL, Kokubu HL, Collins-Williams C. Diagnosis of food allergy by the radio-allergo-sorbent test. J Allergy Clin Immunol 1976;58:477-482.

6. Danneus A, Johansson SGO, Foucard $T$, Ohman S. I Clinical and immunological aspects of food allergy in childhood. Acta Paediatr Scand 1977;66:31-37.

7. Danneus A, Johansson SGO, Foucard T. II Clinical and immunological aspects of food allergy in childhood. Acta Paediatr Scand 1978;67:497-504.

8. David TJ. Conventional allergy tests. Arch Dis Childh 1991;66:281.

9. Dockhorn RJ. Clinical studies of food allergy in infants and children. Ann. Allergy 1987:59:137-140.

10. Ferguson A. Definitions and diagnosis of food intolerance and food allergy: Consensus and controversy. J Pediatr 1992;121 suppl:7-11.

11. Ford RPK. Hill DJ, Hosking CS. Cow's milk hypersensitivity: immediate and delayed onset clinical patterns. Arch Dis Childh 1983;58,856-862.

12. Gerrard JW, MacKenzie JWA, Goluboff N, Garson JZ, Maningas CS. Cow's milk allergy: prevalence and manifestations in an unselected series of newboms. Acta Paediatr Scandl 1973:234, suppl: 1-21.

13. Hattevig G, Kjellman B, Johansson SGO, Bjorksten B. Clinical symptoms and IgE responses to common food proteins in atopic and healthy children. Clin Allergy 1984:14:551-559.

14. Hill DJ. Clinical recognition of the child with food allergy. Ann Allergy 1987:59:141145.

15. Hill DJ, Davidson GP, Cameron DJS, Elarnes GL. The spectrum of caw's milk, allergy in childhood. Acta Paediatr Scand 1979; 68:847-852.

16. Hill DJ, Firer MA, Shelton MJ, Hosking C. Manifestations of milk allergy in infancy: Clinical and immunological findings. J Pediatr 1986:109:270-276.

17. Hoffman DR. Haddad ZH. Diagnosis of IgE-mediated reactions to food antigens by radio-immuno-assay. J Allergy Clin Immunol 1974:54:165-173.

18. Jakobsson I. Lindberg T. A prospective study of cow's milk protein intolerance in swedish infants. Acta Paediatr Scand 1979:68:853-859.

19. Johansson SGA, Dannaeus A, Lilja G. The relevance of anti-food antibodies for the diagnosis of foodallergy. Ann Allergy 1984;53:665-672.

20. Kjellman N-I M. Bjorkstein B, Hattevig G, Falth-Magnusson K. Natural history of food allergy. Ann Allergy 1988; 61:83-87.

21. Lindberg RE, Arroyave C. Levels of $\mathrm{IgE}$ in serum from normal children and allergic children as measured by an enzyme immuno-assay. J Allergy Clin Immunol, 1986; 78:614-618. 
22. Queille C, Saurat JG. Dermatite atopique (eczema constitutionnel). Etude informatisée de 300 observations. Joum Parisienes Pediatr Paris: Ed Flammarion 1981:293-201.

23. Rzany B, Jarisch R, Götz M. Spezifische IgE-Antikörper gegen KuhmilcheiweiB und einzelne Kuhmilchproteine bei Kindem mit Verdacht auf Kuhmilchallergie. Monatschr Kinderheilkd 1986;134:799-803.

24. Sackett DL, Haynes RB, Guyatt GH, Tugwell P. Clinical epidemiology a basic science for clinical medicine. Boston: Little Brown and company 1991:85-153.

25. Sampson HA. The significance of food allergy in atopic dermatitis. In: Harms HK, Wahn U,eds. Food allergy in infancy and childhood. Berlin: Springer Verlag 1989:89. 100.

26. Sampson HA, Albergo R. Comparison of results of skin tests, RAST, and double-blind, placebo-controlled food challenges in children with atopic dermatitis. J Allergy Clin Immunol 1984;74:26-33.

27. Savilahti E: Cow's Milk Allergy. Allergy 1981; 36:73-86.

28. Schrander JJP, Oudsen S, Forget PP, Kuijten RH. Follow-up study of cow's milk protein intolerant infants. Eur J Pediatr 1992;151:783-785.

29. Tainio VM, Savilahti E. Value of immunologic tests in cow's-milk allergy. Allergy 1990;45:189-196.

30. Vandenplas Y, Sacre L. Influences of neonatal serum IgE concentration, family history and diet on the incidence of cow's milk allergy. Eur J Pediatr 1986;145:493-495.

31. Ventura A, Greco L. Cow's milk allergy in the first year of life: an Italian collaborative study. Acta Paediatr Scand 1988;348 suppl:3-14.

32. Weck AL. Immunologic diagnostic tests in food allergy. In: Schmidt F.ed. I und Allergy. Nestlé Nutrition Workshop Series 1989;17:177-186.

33. Wilson $\mathbf{N}$, Hamburger R. Allergy to cow's milk in the first year of life and its prevention. Ann Allergy 1988;61:323-327. 



\section{Chapter 5}

SMALL INTESTINAL MUCOSA

IGE PLASMA CELLS AND

SPECIFIC ANTI COW'S MILK

IGE IN CHILDREN WITH

COW'S MILK PROTEIN

INTOLERANCE

J.J.P. Schrander, J.J.P.F. Dellevoet, J.W. Arends, P.P. Forget, R. Kuijten. 


\subsection{SUMMARY}

In a prospective study we looked for the presence of both IgE plasma cells in small bowel mucosa and specific serum IgE antibodies to cow's milk in children suspected of cow's milk protein intolerance. Thirty one children with complaints possibly due to cow's milk intolerance were submitted to two consecutive cow's milk elimination/challenge tests. The diagnosis of CMPI was confirmed in 16 of our 31 patients on the basis of two positive elimination/challenge tests. IgE plasma cells were found in nine of 16 patients with proven CMPI and in only one of the 15 patients without CMPI $(\mathrm{p}<0.01)$.

The RAST for cow's milk was positive in six of 16 infants with CMPI and in two of the 15 other infants. Serum IgE level was of no use for the diagnosis of CMPI. Neither of these diagnostic procedures was sensitive enough to be used as a screening test for CMPI. Further, the relationship between specific IgE antibodies for cow's milk and the presence of mucosal IgE plasma cells was poor: five of nine infants with CMPI and the presence of mucosal IgE plasma cells had negative RAST results for cow's milk.

\subsection{INTRODUCTION}

The diagnosis cow's milk protein intolerance (CMPI) still relies on cow's milk elimination/challenge tests $(5,9)$ because of poor reliability of histological and immunological criteria.

Although the morphological changes at the level of the intestinal mucosa appear unspecific $(10,18)$, Shiner et al (21) suggested that ultrastructural and immunological changes could be helpful for the diagnosis. Mucosal IgE plasma cells were sought for in several studies with conflicting results $(14,16,18)$. Forget and Arends reported the presence of mucosal IgE plasma cells in several children with cow's milk intolerance (3). The sensitivity of the latter finding is not known. Serum IgE and RAST are usually done to look for an IgE mediated reaction in children suspected of CMPI (17). The sensitivity of the RAST is however, disappointing. It is not known whether the finding of duodenal mucosal IgE plasma cells in infants is related to serum IgE or RAST results.

In the present prospective study we looked specifically for the presence of intestinal IgE plasma cells and their relationship to serum $\mathrm{IgE}$ level and RAST results in children with CMPI. 


\subsection{PATIENTS AND METHODS}

\subsubsection{Patients}

Thirty one consecutive children with an age range varying between 2 months and 2.5 years, had complaints possibly caused by CMPI were studied. Complaints were either gastrointestinal (colic, diarrhoea, vomiting), respiratory (chronic rhinitis, chronic cough, recurrent wheezy bronchitis), cutaneous (eczema, urticaria, angioedema), or general (failure to thrive and crying) and had been present for more than two weeks. According to symptomatology, various diagnostic procedures were undertaken (viral and bacterial stool cultures, small bowel biopsy, sweat test, breath hydrogen test, intraesophageal $\mathrm{pH}$ probe testing, chest radiograph, complete blood count, urine examination, renal- and liver function).

Dietary therapy consisted of a lactose-poor diet, followed by the hypoallergic formula Pregomin (a protein hydrolysate, containing proteins of animal (collagen) and vegetable (soy) origin (Milupa)). If symptoms did resolve on this diet, a cow's milk challenge was performed. Patients relapsing on cow's milk challenge were submitted to a second elimination period followed by challenge. Milk was eliminated for 4 weeks and subsequently reintroduced during both challenges. 16 children from the study group of 31 proved to have CMPI (two positive elimination/challenge tests). There were eight girls and eight boys, the mean age was 10 months, with an age range varying between 3 months and 2 years. Eleven of 16 patients were under one year of age at the time of diagnosis. In the other 15 children of our study group, CMPI was excluded (negative milk elimination/challenge test). The latter group of patients is referred to as sick control group. There were six girls and nine boys, the mean age was 9 months with an age range varying between 2 months and 2.5 years. Twelve of these 15 patients were under one year of age. Informed consent was obtained and the protocol for the study was accepted by the ethics committee of the academic hospital Maastricht.

\subsubsection{Methods}

Duodenal biopsies were taken endoscopically (Olympus) 24-48 hours after a challenge with cow's milk. The pathologist, unaware of clinical data, examined the biopsies for the presence of IgE plasma cells in the lamina propria. The mere presence of one or more IgE positive cell(s) in the whole biopsy tissue was considered abnormal on the basis of our previous experience (4). 


\subsubsection{Immunohistology}

$\mathrm{IgE}$ plasma cells were stained by the immunoperoxidase technique. Duodenal biopsy specimens were fixed in $4 \%$ neutral buffered formalin and processed in paraplast. Five micron sections were cut, dewaxed, rehydrated and blocked for endogenous peroxidase activity in a $0.5 \%$ hydrogen peroxidase solution in absolute methanol. After trypsinisation in a $\mathrm{CaCl} 2 /$ trypsin solution (12) sections were subjected to immunostaining according to the unlabelled peroxidase/antiperoxidase technique (20) for the conventional anti IgE antibodies (Dakopath, Copenhagen, Denmark) and an indirect procedure for the monoclonal anti IgE. The sections were developed with diaminobenzidine and counterstained with haematoxylin. Nasal polyps were used as positive control tissue, whereas negative controls were carried out by replacement of the immune anti-IgE sera by non-immune rabbit and mouse sera.

\subsubsection{IgE and RAST}

Serum IgE concentrations were assessed by means of commercially available immunoradiometric assay (Pharmacia IgE RIACT, Uppsala, Sweden). The assay is calibrated against the second International Reference Preparation $75 / 502$ of human serum IgE from the WHO. It is a solid phase based sandwich technique in which monoclonal antibodies against human IgE are used. One is covalently coupled to the test tube wall and the other is bearing a 125 -Iodine label. The interassay precision of the assay is better than $10 \%$ in the range from 0.2 to 50 (kU/1).

The RAST's have been done using radio immunosorbent test (Phadebas RAST, Pharmacia). Fifty $\mu$ of sample is applied to each disc and incubated for 16-24 hours. Next the discs are washed twice. $50 \mu \mathrm{l}$ of anti IgE- 125 -Iodine is added and this mixture is incubated for another 24 hours. Then the discs are washed three times. The residual activity of the discs is counted in a gamma counter. The RAST results are scored $0-4$ in comparison to the results of reference samples containing birch allergen calibrated versus the above mentioned second international reference preparation. The interassay precision of the assay is better than $10 \%$ over the whole range. The following discs have been used: total milk (F2), beta lactoglobulin (F77) and casein (F78). A RAST score 1 or higher for 1 of the three discs is accepted as positive and expressed as international units per milliliter. The measurement of IgE and RAST was performed during the first period of cow's milk elimination and reintroduction. 


\subsubsection{Statistical analysis}

The Fisher exact test was used for statistical analysis. Sensitivity, specificity and positive predictive value were calculated using standard formulas.

\subsection{RESULTS}

Clinical data as well as biopsy and serological results are shown in Table 1 and 2. No differences were found for age and sex at the moment of diagnosis in children with and without CMPI. Mucosal IgE plasma cells were found in nine of 16 patients with CMPI, whereas this was the case for only one of 15 patients in the sick control group $(\mathrm{p}<0.01)$. The RAST for cow's milk was positive in six of 16 infants with CMPI and in two of the 15 other children. The latter difference was not significant. Both RAST and $\mathrm{IgE}$ plasma cells were positive

Table 1:

Presence of duodenal IgE plasma cells, serum IgE level and RAST results in 16 patients with proven CMPI.

\begin{tabular}{llll}
\hline Patients & $\begin{array}{l}\text { Mucosal IgE } \\
\text { plasma cells }\end{array}$ & $\begin{array}{l}\text { Serum } \\
\text { IgE kU/l }\end{array}$ & RAST \\
\hline 1 & + & 332 & pos \\
2 & + & 315 & pos \\
3 & + & 100 & pos \\
4 & + & 10 & neg \\
5 & + & 7 & neg \\
6 & + & 4 & neg \\
7 & + & 4 & neg \\
8 & + & 3 & pos \\
9 & + & 1 & neg \\
10 & - & 40 & pos \\
11 & - & 30 & neg \\
12 & - & 10 & pos \\
13 & - & 6 & neg \\
14 & - & 4 & neg \\
15 & - & 4 & neg \\
16 & - & 4 & neg \\
\hline
\end{tabular}




\section{Table 2:}

Presence of duodenal IgE plasma cells, serum IgE level and RAST results in 15 sick control children.

\begin{tabular}{llll}
\hline Patients & $\begin{array}{l}\text { Mucosal IgE } \\
\text { plasma cells }\end{array}$ & $\begin{array}{l}\text { Serum } \\
\text { IgE kU/ }\end{array}$ & RAST \\
\hline 1 & + & 2 & neg \\
2 & - & 80 & neg \\
3 & - & 50 & neg \\
4 & - & 20 & pos \\
5 & - & 20 & neg \\
6 & - & 12 & neg \\
7 & - & 12 & neg \\
8 & - & 6 & neg \\
9 & - & 6 & neg \\
10 & - & 6 & neg \\
11 & - & 6 & neg \\
12 & - & 6 & neg \\
13 & - & 6 & neg \\
14 & - & 4 & neg \\
15 & & 1 & neg \\
\hline
\end{tabular}

\section{Table 3:}

Diagnostic criteria of CMPI (percentage).

\begin{tabular}{llcc} 
Diagnostic criteria & Sensitivity & Specificity & Positive predictive value \\
\hline A: Mucosal IgE Plasma Cells & 56 & 93 & 90 \\
B: Positive RAST & 37 & 86 & 75 \\
C: Both A and B & 33 & 100 & 100 \\
\hline
\end{tabular}

in only four of 16 infants with CMPI and in none of our sick controls. Either RAST or IgE plasma cells were positive in 11 of 16 children with CMPI while only three of 15 sick control children had one of these tests positive $(p<0.005)$.

Five of nine children positive for mucosal IgE plasma cells had a negative RAST for cow's milk. There were no differences in symptoms, sex, or age, between the two groups. The sensitivity, specificity and positive predictive value of these various diagnostic tools are shown in Table 3. 


\subsection{DISCUSSION}

In this study we evaluated the diagnostic value of intestinal mucosal IgE plasma cells, serum IgE level and specific serum anti cow's milk IgE for the diagnosis of CMPI. Results of these diagnostic procedures in children with and without CMPI were compared. The diagnosis of CMPI was based on elimination/challenge tests. Several authors advise to use two successive positive challenges as diagnostic criterion $(5,9)$. This criterion was used in the present study. Most authors would accept that the presence of anti-milk antibody in a symptomatic baby is a prove for the diagnosis of milk allergy.

Mucosal IgE plasma cells were present in nine of 16 patients with proven CMPI and in only one of the 15 sick control patients $(\mathrm{p}<0.01)$. The predictive value of this finding was $90 \%$. In patients with CMPI and negative mucosal IgE plasma cells, CMPI could be mediated either by a non $\operatorname{IgE}$ dependant immunological mechanism or we might have failed to detect mucosal IgE plasma cells if the latter have a "patchy" mucosal distribution (10). Patterson et al (14) definitely showed $\mathrm{IgE}$ plasma cells in human intestinal mucosa with immunoelectron microscopy. Increased numbers of $\operatorname{lgE}$ plasma cells have been reported in celiac disease (19), in spirochaetosis (6) and in proctitis $(7,13,15)$; however, controversial results have been reported for patients with CMPI $(3,16,18,21)$. Hypersensitivity to other foods could also be associated with mucosal IgE plasma cells, but we did not study this. Savilathi (18) did not find any IgE plasma cells in patients with food allergy. The differences could be due to the use of various immunohistochemical techniques that differ in sensitivity and because of specificity problems with the anti-sera especially before 1980 (1). The IgE level was of no value in the differentiation between children with and without CMPI. This result agrees with other published data $(2,8)$.

A positive RAST was found in six of 16 infants with CMPI and in one of 15 sick controls, the predictive value was $75 \%$. Similar results have been reported by Rzany et al (17). The immunological mechanism in patients with CMPI and a negative RAST could either be non IgE dependent or an IgE mediated reaction strictly localized to the gut mucosa. This last hypothesis was supported by our finding of IgE plasma cells in 5 infants with CMPI and a negative RASTs. In several food intolerant patients with both negative RASTs and skin prick tests Marcucci (11) reported the presence of specific IgE against food allergens in intestinal washings. This supports the hypothesis of a strictly local, intestinal specific IgE production. This local production of IgE, not reflected in the serum is contrary to animal control studies examining this question. If one accepts that either the presence of mucosal IgE plasma cells or a positive RAST supports the diagnosis of an IgE mediated immunological reaction, 11 of 16 infants with CMPI showed an IgE mediated immunological reaction (predictive value $84 \%$ ). 


\subsubsection{Conclusion}

We showed that intestinal mucosal IgE plasma cells can be found in patients with CMPI even in the absence of abnormal IgE levels or RAST results. Consequently a classification of patients into $\mathrm{IgE}$ mediated or non $\mathrm{IgE}$ mediated groups should not be made on the basis of serum IgE levels and RAST results alone. The presence of both a positive RAST and IgE plasma cells in the gut provides a $100 \%$ positive predictive value, but with only $33 \%$ specificity. In view of the low numbers the confidence interval of this finding has an enormous range. Our study showed that examination of intestinal mucosal biopsies for the presence of $\mathrm{IgE}$ plasma cells can be helpful for the diagnosis CMPI.

\section{Acknowledgments}

This study was supported by a grant of Milupa Aktiengesellschaft, Deutschland. 


\section{REFERENCES}

1. Brandtzaeg P, Baklien $\mathrm{K}$. Inclonclusive immunohistochemistry of human IgE in mucosal pathology. Lancet 1976;: 1297-1298.

2. Dockhom RJ. Clinical studies of foodallergy in infants and children. Ann Allergy 1987:59:137-140.

3. Forget P, Arends JW. Cow's milk protein allergy and gastro-esophageal reflux. Eur J Pediatr 1985;144:298-300.

4. Forget $\mathrm{P}$, Arends JW, van Zandvoort R. Immunoglobulin E in dunne darm mucosa: een kwantitatieve analyse. Tijdschr Kindergeneeskd 1985;53:56-59.

5. Gerrard JW, MacKenzie JWA, Goluboff N, Garson JZ, Maningas CS. Cow's milk allergy: Prevalence and manifestations in an unselected series of newboms. Acta Pediatr Scand 1973;234 suppl:1-15.

6. Grebbers JO, Ferguson DJ, Mason C, Crucioli V, Jewell DP. Lokale immunreaktion bei intestinaler spirochatose des menschen. Schweiz Med Wochenschr 1987;1 17:10871091.

7. Heatley R, Calcraft BJ, Fifield R, Rhodes J, Whitehead RH, Newcastle RG. Immunoglobuline $\mathrm{E}$ in rectal mucosa of patients with proctitis. Lancet 1975; II:110 - II2.

8. Hill DJ, Davidson GP, Cameron DJS, Barnes GL. The spectrum of cow's milk allergy in childhood. Acta Paediatr Scand 1979;68:847-852.

9. Jakobsson I, Lindberg T. A prospective study of cow's milk protein intolerance in swedish infants. Acta Paediatr Scand 1979;68:853-859.

10. Manuel PD, Walker-Smith JA, France NE. Patchy enteropathy in childhood. Gut 1979;20:211-215.

11. Marcucci F, Sensi LG, Bizzari G. Specific IgE and inhalant allergens in intestinal washings of children affected by atopic eczema. Clin Allergy 1985;15:345-354.

12. Mepham BL, Frater W, Mitchel B. The use of proteolytic enzymes to improve Ig staining by the PAP technique. J Histochem 1979; 1 1:345-357.

13. O'Donoghue DP, Kumar P. Rectal IgE cells in inflammatory bowel disease. Gut 1979;20:149-153.

14. Patterson S, Roebuck P, Platts-Mills TAE, Shiner M, Kingston D, Pearson JR. IGE plasma cells in human jejunum demonstrated by immuno electron microscopy. Clin Exp Immunol 1981:46:301-304.

15. Rosekrans PCM, Meijer CJ, van de Wal AM. Allergic proctitis, a clinical and immunopathological entity. Gut 1980;21:149-153.

16. Rosekrans PCM, Meijer CILM, Comelisse CJ, vd Wal AM, Lindeman J. Use of morphometry and immunohistochemistry of small intestinal biopsy specimens in the diagnosis of food allergy. J Clin Path 1980;33:125-130.

17. Rzany B, Jarisch R, Gotz M. Spezifische IgE-antikorper gen Kühmilchproteine bei Kinder mit verdacht auf Kïhmilch Allergie. Monalsschr Kinderheilkd 1986;134:799-803.

18. Savilathi E. Immunohistochemical study of the malabsorption syndrome with cow's milk intolerance. Gut 1973;14:491-501.

19. Scott BB, Goodall A, Stephenson P. Small intestinal plasma cells in coeliac disease. Gut $1984 ; 25: 41-46$.

20. Stemberger LA. Immunohistochemistry. Englewood Cliffs NJ: Prentis Hall Inc. 1974.

21. Shiner M, Ballard J, Smith ME. The small intestinal mucosa in cow's milk allergy. Lancet 1975;I:136-140. 



\section{Chapter 6}

51-Cr EDTA INTESTINAL PERMEABILITY IN CHILDREN WITH COW'S MILK PROTEIN INTOLERANCE

J.J.P. Schrander, R.W.M. Unsalan-Hooyen, P.P. Forget, J. Jansen. 


\subsection{SUMMARY}

Making use of 51-Cr EDTA as permeability marker, we measured intestinal permeability in a group of 20 children with proven cow's milk protein intolerance (CMPI), a group of 17 children with similar complaints where CMPI was excluded (sick controls), and a group of 12 control children.

51-Cr EDTA test results (mean +/- SD) were $6.85 \%+/-3.64 \%, 3.42 \%+/$ $0.94 \%, 2.61 \%+/-0.67 \%$, in the group with CMPI, the sick control and the control group respectively. When compared to both control groups patients with CMPI showed a significantly increased small bowel permeability. We conclude that the 51-Cr EDTA test can be helpful for the diagnosis of CMPI.

\subsection{INTRODUCTION}

A defect in antigen exclusion (IgA deficiency, defective mucosal barrier at the level of the gastrointestinal mucosa) is thought to play an important role in the development of cow's milk protein intolerance (CMPI) (9). In recent years intestinal permeability has been investigated in various clinical conditions making use of large (lactulose, 51-Cr EDTA) and small (mannitol, rhamnose) permeability markers $(1,13,16,19)$. A decreased mucosal barrier integrity as measured by intestinal permeability tests could be implicated in the pathogenesis of food intolerance in children.

To the best of our knowledge, 51-Cr EDTA intestinal permeability has not been investigated in CMPI. In the present study we aimed at comparing intestinal permeability to 51-Cr EDTA in a group of 20 patients with proven CMPI, a group of 17 patients with similar clinical manifestations where CMPI was excluded (sick controls) and a group of 12 control patients. In this study two positive cow's milk elimination/challenge trials were considered diagnostic of CMPI.

\subsection{MATERIAL AND METHODS}

\subsubsection{Patients}

Thirty seven children having complaints possibly caused by cow's milk intolerance were entered in the study group. Complaints were either gastrointestinal (colics, diarrhoea and vomiting), respiratory (chronic rhinitis, chronic cough, and recurrent wheezy bronchitis), cutaneous (eczema, exanthema, urticaria and angioedema), or general (failure to thrive, crying) and were present for more than two weeks. 
According to symptomatology, various diagnostic procedures were undertaken: viral and bacterial stool cultures, small bowel biopsy, sweat test, breath hydrogen test, intraesophageal $\mathrm{Ph}$ probe testing, chest radiograph, full blood count, urine examination, kidney and liver function. Dietary therapy consisted of a lactose-poor diet, followed by Pregomin, a protein hydrolysate, containing proteins of animal (collagen) and vegetable (soy) origin, if symptoms did not resolve. Two weeks later, cow's milk challenges were performed with full amounts of milk and followed 12 hours later by a 51-Cr EDTA permeability test. Patients relapsing on the first cow's milk challenge were submitted to a second elimination/challenge test. A positive challenge was defined by the recurrence of the patients' complaints.

From the study group, 20 children proved to have CMPI (two positive elimination/challenge trials). They were 6 girls and 14 boys, with a mean age was 19 months and range varying between 3 months and 8.3 years; 15 of 20 patients were under 1 year of age at the moment of diagnosis. In 17 children in our study group, CMPI could be excluded (negative milk elimination/challenge trials). These latter patients formed our sick control group. They were 6 girls and 11 boys, with a mean age of 13 months and range between 2 and 36 months; 11 out of 17 patients were under 1 year of age. During clinical investigation, no abnormalities were found and no clear diagnosis could be established in most of these sick babies. Symptoms disappeared spontaneously within at most eight weeks. The control group consisted of 12 children with minor medical problems which healed rapidly under conventional therapy. Our control patients were assumed to have a normal small bowel mucosa. They were 6 girls and 6 boys, with a mean age of 16 months and range between 2 and 56 months; 6 of 12 patients were under 1 year of age. The diagnosis were inguinal hernia, failure to thrive due to feeding errors or psychosocial problems.

\subsubsection{Methods}

A 51-Cr EDTA test (3) to measure small intestinal permeability, was performed in all 49 patients. The test was performed as follows:

After an overnight's fast 50 or $100 \mathrm{uCi}$ (according to age) 51-Cr EDTA was given orally in $10 \mathrm{ml}$ distilled water. Feeding was allowed two hours later. Urine was collected for 24 hours. Patients where urinary losses occurred were excluded from the study. The urine samples were counted in a gamma counter. Ten milliliters of a $1: 200$ dilution of the oral doses was similarly counted. Radio activity excreted in the urine over 24 hours was expressed as a percentage of the oral dose. The estimated effect of radiation on the total body is $<0.05 \mathrm{mSv}$, on stomach or small bowel is $<0.1 \mathrm{mSv}$, on large bowel is $<1.5 \mathrm{mSv}$ and on gonads is $<0.2 \mathrm{mSv}$. All of these values are within the range of natural background radiation for one year $(4,16)$. 


\subsubsection{Statistical analysis}

A Wilcoxon's nonparametrical test and Fisher's exact probability test were used.

\subsection{RESULTS}

The means and standard deviations of permeability data were $6.85 \%$ - $3.64 \%$ (see Table 1), $3.42+/-0.94 \%$ (see Table 2), 2.61 +/- 0.67\% (minimum 1.3\%, maximum $5.1 \%$ ), for the CMPI, sick control and control group respectively. The difference in permeability between the group with CMPI and the 'sick control group' was statistically significant ( $p<0.01)$, as was the difference between the cow's milk protein intolerant group and the control group $(\mathrm{p}<0.01)$. However, the test, as illustrated in the Tables, did not discriminate all children with CMPI.

Table 1:

Small bowel permeability to $51-\mathrm{Cr}$ EDTA in 20 children with CMPI.

Complaints: $\quad$ 51-Cr EDTA in \%

$\begin{array}{lr}\text { Chronic cough } & 9.1 \\ \text { Crying } & 15.6 \\ \text { Crying, colics } & 4.0 \\ \text { Crying, colics } & 7.7 \\ \text { Crying, failure to thrive } & 5.7 \\ \text { Diarrhoea } & 13.4 \\ \text { Diarrhoea, eczema } & 4.3 \\ \text { Diarrhoea, eczema } & 12.1 \\ \text { Diarrhoea, eczema } & 7.3 \\ \text { Eczema } & 2.3 \\ \text { Eczema } & 2.7 \\ \text { Eczema, vomiting } & 6.1 \\ \text { Failure to thrive, colics } & 5.3 \\ \text { Failure to thrive, crying } & 7.2 \\ \text { Asthma } & 7.0 \\ \text { Asthma } & 5.3 \\ \text { Asthma, eczema } & 10.1 \\ \text { Urticaria } & 5.4 \\ \text { Vomiting } & 3.1 \\ \text { Vomiting } & 3.3 \\ \end{array}$


Table 2:

Small bowel permeability to 51-Cr EDTA in a sick control group of 17 children (no CMPI).

Complaints

51-Cr EDTA \%

Chronic cough

Colics

Crying

Crying, vomiting

Diarrhoea

Diarrhoea

Diarrhoea, failure to thrive

Eczema

Eczema, chronic cough

Failure to thrive

Failure to thrive

Failure to thrive

Failure to thrive

Failure to thrive, diarrhoea

Asthma

Asthma, vomiting

Vomiting

\section{5}

3.2

4.9

3.3

3.3

3.5

2.5

2.7

4.5

4.8

3.8

2.9

2.5

5.0

2.4

1.8

3.6

Table 3:

Relationship between 51-Cr EDTA permeability and results of the cow's milk elimination/challenge trials in 37 children suspected of CMPI.

\section{$\mathrm{CMPI}+\quad \mathrm{CMPI}-$}

$\begin{array}{lrr}51 \mathrm{Cr} \text { EDTA } \geq 4.0 \% & 16 & 5 \\ 51 \mathrm{Cr} \text { EDTA }<4.0 \% & 4 & 12\end{array}$

Significance: $p<0.005$ (Fisher's exact probability test).

As shown in Table 3, a significant $(p<0.005)$ relationship was found between intestinal permeability results and results of the cow's milk elimination/challenge trial. The best results for the latter relationship were obtained when using a cut off value of $4 \%$.

We found no correlation between 51-Cr EDTA test results and either patients age, sex, or presenting complaints. 


\subsection{DISCUSSION}

An increased intestinal permeability for food antigens, is thought by many authors to be an important factor in the development of food intolerance.

Making use of 51-Cr EDTA as a permeability marker, we aimed in the present study at evaluating intestinal permeability in a group of young children clinically suspected of having CMPI. On the basis of cow's milk elimination/challenge tests, this group could be subdivided in a group with proven CMPI and a group where CMPI was excluded (sick control group).

We further compared results obtained in this study group with those of a control group. In the control patients the absence of small bowel disease was essentially based on clinical and follow-up data. Permeability results in these patients did closely correspond to published data for either control children (13). or normal aduits $(7,13,18,21)$, which made it likely that these control values are representative of the normal population. Similarly to data reported by other authors, we found no relationship between age and permeability results (13).

Our results showed small bowel permeability to be significantly increased in babies with CMPI, compared to both our sick control group and our control group.

Intestinal permeability has been shown to be increased in various conditions associated with small bowel inflammation such as acute gastroenteritis $(13,12)$, celiac disease $(2,3,7,10,19)$, Crohn's disease $(4,18,19)$, and cystic fibrosis (16). The test is also positive in patients using NSAID's $(6,11,14,17,22)$, alcohol $(5,8,11)$, cytotoxic drugs (21), and after heavy physical exertion (11).

Although we realize the lack of specifity of intestinal permeability tests, our findings showing a significant correlation between permeability results and the results of cow's milk elimination/challenge tests suggest that investigation of intestinal permeability can offer help for the diagnosis of CMIPI.

We do not know whether the increased permeability found in babies with CMPL is a primary or a secondary event. More research has to be done to answer this ąuestion. In some conditions, increased permeability reverts to normal after medical control of the condition (15). In other conditions, such as treatment with cytostatics (21), treated Crohn's disease (4) and alcohol abuse (5) a relation has been found between disease severity and the results of the 51-Cr EDTA iest.

Onily few data are availabile concerning the relationship between 51-Cr EDTA intestinal permeability on the one hand and antigen permeability on the other. In a recent study performed in rats, such a relationship between protein and $51 . \mathrm{Cr}$ EDTA permeability has been shown to exist (20). If these results also apply to children, antigen exposure of mucosal immunocompetent cells would be increased in many intestinal inflammatory conditions, and, speculatively CMPI would only develop in those babies showing a disordered function of the mucosal immunological system. 
Although 51-Cr EDTA is said to be the most sensitive probe for measuring intestinal permeability (13) practical difficulties, such as the need to collect 24$\mathrm{h}$ urine samples in infants, and the parents' concern about the use of a radio-active substance do arise and present important limitations of this test in children.

\section{Acknowledgments}

The hypo-allergenic feeding Pregomin was kindly provided by Milupa. 


\section{REFERENCES}

I. Andre C, Andre F, Colin L, Cavagna S. Measurement of intestinal permeability to mannitol and lactulose as a means of diagnosing food allergy and evaluating therapeutic effectiveness if disodium cromoglycate. Ann Allergy 1987;59:127-130.

2. Behrens RH, Szaz KF, Northrop. C, Elia M, Neale G. Radionucleide tests for the assessment of intestinal permeability. Eur J Clin Invest 1987; 17:100-105.

3. Bjarnason I, Peters TJ, Veall N. A persistent defect in intestinal permeability in coeliac disease demonstrated by a $51 \mathrm{Cr}$ labelled EDTA absorption test. Lancet 1983;I:3235.

4. Bjamason I, O'Morain C, Levi AJ, Peters TJ. Absorption of 51-chromium-labeled ethylenediaminetetraacetate in inflammatory bowel disease. Gastroenterology 1983; 85:318-322.

5. Bjarnason I, Ward K, Peters TJ. The leaky gut of alcoholism: possible route of entry for toxic compounds. Lancet 1984;I:179-182.

6. Bjarnason I, Williams P, So A. Intestinal permeability and inflammation in rheumatoid arthritis: effects of non-steroidal anti-inflammatory drugs. Lancet 1984;[1:1171-1174.

7. Bjarnason I, Marsh MN, Price A, Levi AJ, Peters TJ. Intestinal permeability in patients with coeliac disease and dermatitis herpetiformis. Gut 1985;26:1214-1219.

8. Bjarnason I, Smethurst P, Levi AJ, Peters TJ. Intestinal permeability to 51-Cr EDTA in rats with experimentally induced enteropathy. Gut 1985;26(6):579-585.

9. Brostoff J, Challacombe SJ, eds. Food allergy and intolerance. London: Baillière Tindall 1987:2091-223.

10. Cobden I, Hamilton I, Axon ATR. Intestinal permeability in coeliac disease (letter). Lancet 1983;1:829.

11. Editorial: Intestinal permeability, Lancei 1985; I:256-258.

12. Ford RPK, Menzies IS, Philips AD, Walker-Smith JA, Turner MW. Intestinal sugar permeability: relationship to diarrhoeal disease and small bowel morphology. J Pediatr Gastroenterol Nutr 1985;4:568-574.

13. Forget $P_{*}$ Sodoyez-Goffaux F, Zappitelli A. Permesbility of the small intestine to $51-\mathrm{Cr}$ EDTA in children with acute gastroenteritis or eczema. J Pediatr Gastroenterol Nutr 1985;4:393-396.

14. Jenkins RT, Rooney PJ, Jones DB, Bienenstock J, Goodacre RL. Increased intestinal permeability in patients with rheumatoid arthritis: a side-effect of oral nonsteroidal anti-inflammatory drug therapy? Br J Rheumatol 1987;26(2): 103-107.

15. Jenkins RT, Chem C. Jones DB, Goodacre RL, Collins SM, Hunt RH, Bienenstock S. Reversibility of increased intestinal permeability to 51-Cr EDTA in patients with gastrointestinal inflammatory diseases. Am J Gastroenterol 1987;82:1159-1164.

16. Leclercq-Foucart J, Forget P. Sodoyez-Goffaux F, Zappitelli A. Intestinal permeability to 51-Cr EDTA in children with cystic fibrosis. J Pediatr Gastroenterol Nutr 1986; 5:384-387.

17. Mieland H, Vey EM. NSAID and the leaky gut. Lancet $1985 ; \mathrm{I}: 218$.

18. O'Morain CA, Abelow AC, Chervu LR, Fleischner GM, Das KM. Chromium 51 ethylenediaminetetraacetate test: a useful test in the assessment if inflammatory bowel disease. J Lab Clin Med 1986;108:430-435.

19. Pearson ADJ, Eastham EJ, Laker MF, Craft AW, Nelson R. Intestinal permeability in children with Crohn's disease and coeliac disease. Br Med J 1982;285:20-21.. 
20. Ramage JK, Stanitz A, Shicchitano R, Hunt RH, Perdue MH. Effects of immunologic reactions in rat intestinal epithelium. Gastroenterology 1988;94:1368-1375.

21. Selby P, McElwain TJ, Crofts M, Lopes N, Mundy J, 51-Cr EDTA test for intestinal permeability (letter). Lancet 1984;1I:38-39.

22. Simpson LO. NSAID and the leaky gut. Lancet 1985;1:218-219. 



\section{Chapter 7}

\section{FOLLOW UP STUDY OF COW'S MILK PROTEIN INTOLERANT INFANTS}

J.J.P. Schrander, S. Oudsen, P.P. Forget, R.H. Kuijten. 


\subsection{ABSTRACT}

Over a period of 4 years, 88 infants with cow's milk protein intolerance (CMPI) were followed prospectively in order to evaluate the persistence of CMPI and its relationship between either serum IgE levels or RAST results for cow's milk. After exclusion of lactose intolerance, two positive cow's milk elimination/challenge tests were considered diagnostic for CMPI.

At the age of $1,2,3$, and 4 years respectively, $85 \%, 78 \%, 49 \%$ and $33 \%$ of the children still were cow's milk intolerant. Initial serum values of $\operatorname{IgE} \geq 10$ $\mathrm{kU} / \mathrm{l}$ indicated a late development of tolerance to cow's milk proteins. At the age of four years $90 \%$ of infants with initial $\mathrm{IgE}$ levels $<10 \mathrm{kU} / \mathrm{l}$ had become tolerant for cow's milk while this was the case for only $47 \%$ of the infants with initial IgE levels $\geq 10 \mathrm{kU} / \mathrm{l}$. Initial RAST results to cow's milk bore no obvious relationship to outcome.

\subsection{INTRODUCTION}

Since 1966, the term allergy has been mostly used to describe immunologically mediated hypersensitivity reactions $(11,13)$. Not all adverse reactions to cow's milk proteins are immunologically mediated, therefore the term cow's milk allergy should not be used routinely. For any adverse reaction to cow's milk proteins giving symptoms of the gastrointestinal tract, skin or respiratory tract, the term cow's milk protein intolerance (CMPI) is preferred (12)

The reported duration of CMPI varies in the literature. According to the clinical follow-up study of Kuitunen et al (17) clinical symptoms of CMPI disappeared at the age of about 1 year. Others state that most infants have become tolerant before the age of $3(1,3,15,19)$.

The aim of the present study was to evaluate the duration of clinical symptoms in a prospective study of patients with CMPI on the basis of a long term follow up and to determine whether either initial serum IgE levels or RAST results, as parameters of type I hypersensitivity reactions, had any predictive value.

\subsection{MATERIALS AND METHODS}

\subsubsection{Patients}

A study group of 100 infants with CMPI was selected at our outpatient department. Symptoms were either gastro-intestinal (colics, diarrhoea and vomiting), respiratory (chronic rhinitis, chronic cough and recurrent wheezy bronchitis), 
cutaneous (eczema, exanthema, urticaria and angioedema), or general (failure to thrive and crying) and were present for more than 2 weeks. Other diseases such as infantile pyloric stenosis, infectious gastroenteritis or cystic fibrosis were excluded.

In order to exclude lactose intolerance the first dietary step consisted of the introduction of a lactose-poor infant feeding (Nutrilon Laag Lactose, Nutricia, 1.3 gram lactose $/ 100 \mathrm{ml}$ ). After one week, if symptoms did not resolve, cow's milk elimination/challenge tests were performed using a protein hydrolysate formula (Pregomin, Milupa). A positive challenge was defined as the recurrence of the patients former complaints. Infants with gastrointestinal- and respiratory symptoms were challenged after 2 weeks and infants with cutaneous manifestations were challenged after 4 weeks. The challenges in patients with gastro-intestinal symptoms were done with full amounts of milk. In most children with respiratory- and cutaneous symptoms the challenges were performed with rising amounts of milk 10,30,50,100 ml. The challenges were not placebo controlled and were evaluated by one paediatrician (J.J.P.S.). The diagnosis of CMPI was based on two positive cow's milk elimination/challenge tests after exclusion of lactose intolerance.

All infants with CMPI were enroled into the study. All children were checked every year irrespective of the presence or severity of symptoms. Infants were excluded when they moved out of the study area.

The serum IgE level and RAST result were determined during the first period of cow's milk elimination and reintroduction. All intolerant children were challenged once a year and if the child still appeared intolerant the cow's milk free diet was prescribed for another year. No effort was made to examine type III or IV allergic reactions.

\subsubsection{Laboratory investigations}

Serum IgE concentrations were assessed by commercially available immunoradiometric assay (Pharmacia IgE RIACT, Uppsala, Sweden) The assay was calibrated against the second International Reference Preparation 75/502 of human serum immunoglobulin E from the WHO and is a solid phase based sandwich technique in which monoclonal antibodies against human $\operatorname{IgE}$ are used. One is covalently coupled to the test tube wall and the other bears a 125 lodine label. The interassay precision of the assay was better than $10 \%$ in the range from 0.2 to $50(\mathrm{kU} / \mathrm{l})$.

RAST was done using a radio immunosorbent test (Phadebas Rast, Pharmacia Freiburg, FRG). $50 \mu \mathrm{l}$ of sample was applicated to each disc and incubated for 16-24 h. The discs were then washed twice. $50 \mu \mathrm{l}$ of anti IgE- 125 Iodine was added and this mixture incubated for another $24 \mathrm{~h}$. The discs were then washed 
three times. The residual activity of the discs was counted in a gamma counter. The RAST results were scored 0 - 4 compared to the results of reference samples containing birch allergen calibrated versus the above mentioned second International Reference Preparation. The interassay precision of the assay was better than $10 \%$ over the whole range. The following discs were used: total milk (F2), beta lactoglobulin (F77) and casein (F78). A Rast score of 1 or higher for one of the three discs was accepted as positive and expressed as kU/l.

\subsubsection{Statistical analysis}

The Fisher test was used for statistical analysis.

\subsection{RESULTS}

We enroled 100 infants in the study during which 11 children moved out of the area during the study. One parent refused to participate in the follow up study. 88 children were available for evaluation.

\subsubsection{Recovery from CMPI}

We followed 88 infants for 1 year. Tolerance to cow's milk developed in 13 patients ( $15 \%), 75$ remaining milk intolerant. Out of the remaining 75 children who were followed for 2 years, tolerance to cow's milk developed in the 2nd year in $16(21 \%)$ while 59 remained cow's milk intolerant. From the latter 59 infants who were followed for 3 years 16 children $(27 \%)$ developed tolerance to cow's milk in the $3 \mathrm{rd}$ year and 43 remained intolerant. Out of the 43 infants who were followed for 4 years 14 children (32\%) developed tolerance to cow's milk in the 4th year while 29 remained intolerant.

The percentage of all children developing tolerance for cow's milk was $15 \%$, $33 \%, 51 \%$ and $67 \%$ after $1,2,3$ and 4 years of follow up respectively. Adverse reactions to other nutrients, especially to eggs and fruit developed in 38 infants $(42 \%)$. Of the infants, 42 had gastro-intestinal complaints as main symptoms. Of them 36 were tolerant for cow's milk at 4 years of age.

\subsubsection{Recovery from CMPI and IgE levels}

The serum IgE levels were measured in all 88 infants. Results of IgE with a cut off value of $10 \mathrm{kU} / \mathrm{l}$ are shown in Table 1 .

At the ages of 1,2,3 and 4 the percentage of children becoming cow's milk tolerant was significantly higher (see Table 1) in patients with a normal $\operatorname{IgE}(<$ $10 \mathrm{kU} / \mathrm{l})$ when compared to those with an elevated $\operatorname{IgE}(\geq 10 \mathrm{kU} / \mathrm{l})$. Table 1 
Table 1:

Recovery from CMPI according to lgE results during the first four years of life

\section{Healing rate}

\begin{tabular}{|c|c|c|c|c|}
\hline Periods (years): & $0-1$ & $1-2$ & $2-3$ & $3-4$ \\
\hline Total & $13 / 88=15 \%$ & $16 / 75=21 \%$ & $16 / 59=27 \%$ & $14 / 43=33 \%$ \\
\hline IgE pos. ( $210 \mathrm{kU} / \mathrm{l})$ & $3 / 47=6 \%$ & $5 / 44=11 \%$ & $6 / 39=15 \%$ & $8 / 33=24 \%$ \\
\hline IgE neg. $(<10 \mathrm{kU} / \mathrm{h})$ & $10 / 41=24 \%$ & $11 / 31=36 \%$ & $10 / 20=50 \%$ & $6 / 10=60 \%$ \\
\hline \multicolumn{5}{|l|}{ Differences between } \\
\hline both groups & $\mathrm{p}<0.02$ & $p<0.02$ & $\mathrm{p}<0.007$ & $\mathrm{p}<0.05$ \\
\hline
\end{tabular}

shows the healing rates at different ages in the total group of infants, in infants with an initially elevated $\mathrm{IgE}$ and in infants with a low initial $\mathrm{IgE}$. Of infants with mainly gastrointestinal symptoms, 34/42 had an IgE level $<10 \mathrm{kU} /$.

Sensitization to other nutrients was seen in 29 infants with an elevated IgE $(\geq 10 \mathrm{kU} / \mathrm{l})$ as compared to 9 infants with a normal $\operatorname{IgE}(<10 \mathrm{kU} / \mathrm{l})(\mathrm{p}<0.01)$.

\subsubsection{Recovery from CMPI and RAST results}

The RAST was performed in all 88 infants. The results are shown in Table 2. No significant relationship was found between RAST results and recovery from CMPI.

Results of the RAST had no predictive value for the development of tolerance. Of infants with gastrointestinal symptoms, $3 / 42$ had a positive RAST for cow's milk.

Table 2:

Recovery of CMPI according to RAST results during the first four years of live

Healing rate

\begin{tabular}{|c|c|c|c|c|}
\hline Periods (years): & $0-1$ & $1-2$ & $2-3$ & $3-4$ \\
\hline Total & $13 / 88=15 \%$ & $16 / 75=21 \%$ & $16 / 59=27 \%$ & $14 / 43=33 \%$ \\
\hline RAST positive & $4 / 35=11 \%$ & $5 / 3 !=16 \%$ & $7 / 26=27 \%$ & $5 / 19=26 \%$ \\
\hline RAST negative & $9 / 53=17 \%$ & $11 / 44=25 \%$ & $9 / 33=27 \%$ & $9 / 24=38 \%$ \\
\hline $\begin{array}{l}\text { Differences between } \\
\text { both groups }\end{array}$ & NS & NS & NS & NS \\
\hline
\end{tabular}




\subsection{DISCUSSION}

The preferred procedure for the diagnosis of CMPI consists of performing cow's milk elimination/challenge tests $(5,12)$. Originally, according to Goldman et al (8), the criteria for CMPI consisted of three positive elimination/challenge tests with cow's milk. At present the number of challenges is still a matter of discussion, several authors advise to use two positive elimination/challenge tests as diagnostic criterium $(7,12)$.

In most studies the infants with CMPI were followed for three years or less, with the exception of Bishop et al (2) who followed their study group for 6 years. We studied 88 infants with CMPI. Thirteen infants (15\%) of our study group became tolerant to cow's milk during their 1st year of life. This is a low percentage compared to findings of other investigators $(12,17)$. A very similar percentage of $18 \%$ was found by Gerrard et al (7). Only one study reports a still lower healing rate $(6 \%)$ during the 1st year of life (9). Twentynine children (33\%) of our study group had become tolerant at the age of 2 years. These results are comparable with those of Gerrard et al (7) and Bishop et al (2) and lower than other reported data $(12,17)$. Fortyfive infants $(51 \%)$ of our study group had become tolerant before their 3rd birthday. Hill et al (9) found a higher $(65 \%)$ and Gerrard et al (7) a lower value. At 4 years of age $67 \%$ of our study group was tolerant to cow's milk. The percentage found by Bishop et al is $10 \%$ lower than the results of our study at the age of 4 years. Published data of Gerrard, Hill and Jakobson after the age of 3 years are not available. In our study a trend was found for children with gastro-intestinal symptoms to develop tolerance earlier than children with skin or respiratory symptoms. Contrary to children with symptoms of other organ systems, most infants with gastrointestinal symptoms had a low total IgE. A similar trend has been reported by Kjellmann et al (15).

The value of serum IgE level and RAST results in diagnosing CMPI is still a subject of discussion $(2,6,10,16,20)$. We wondered whether there was any relationship between test results and pragnosis of CMPI. Sarnpson and Scanlon (20) found no correlation between recovery from food hypersensitivity and results of total serum IgE in children with atopic dermatitis. In our study we looked at $\mathrm{IgE}$ values of 5-, 10-, 25- and $50 \mathrm{kU} / \mathrm{l}$ and found that only levels of total serum $\mathrm{IgE} \geq 10 \mathrm{kU} / \mathrm{h}$ had a prognostic value as far as the development of tolerance was concerned. An IgE level of $\geq 10 \mathrm{kU} / \mathrm{l}$ under 1 year of age is usually considered abnormal $(14,15,18)$. Children with an elevated $\lg E$ had a lower healing rate at all ages when compared to patients with normal serum $\operatorname{lgE}$ initially. At the age of 4 years $90 \%$ of infants with initial $\mathrm{IgE}$ levels $<10 \mathrm{kU} / \mathrm{l}$ had become tolerant for cow's milk while this was the case for only $47 \%$ of the infants with initial IgE levels $\geq 10 \mathrm{kU} /$. It has been stated in the literature that a fall in IgE anti-cow milk antibody levels is not associated with the development 
of tolerance (10). In children with chronic diarrhoea due to CMPI, Businco et al. (4) found the tendency for CMPI to persist throughout childhood to be related to RAST positivity. In our study no association between RAST results and the prognosis of CMPI during the first 4 years of life was seen. Maybe the number of cases studied was to small in order to detect a difference in outcome.

We conclude that the duration of CMPI is longer than expected from the literature and that CMPI still persists after 4 years in $33 \%$ of the patients. Infants with mainly gastro-intestinal symptoms have almost all recovered from cow's milk intolerance at 4 years of age ( $86 \%$ ). Our study further shows that an initial serum IgE level above $10 \mathrm{kU} / \mathrm{h}$ is predictive of long lasting CMPI while RAST results have no prognostic significance.

\section{Acknowledgements}

The hypoallergenic feeding Pregomin was kindly provided by Milupa. 


\section{REFERENCES}

1. Bahna SL, Heiner C. Allergies to milk. New York, Grun \& Stratton 1980.

2. Bishop JM, Hill DJ, Hosking CS. Natural history of cow's milk allergy: Clinical outcome. J Pediatr 1990;1 16:862-867.

3. Bock SA. Prospective appraisal of complaints of adverse reactions to foods in children during the first 3 years of life. Pediatrics 1987;79:683-688.

4. Businco L, Benincori N, Cantani A, Tacconi L, Picarazzi A. Chronic diarrhea due to cow's milk intolerance. Arch Dis Childh 1975;50:351-354.

5. Clein NW. Cow's milk allergy in infants and children. Int Arch Allergy 1958:13:245256.

6. Dockhom RJ. Clinical studies of foodallergy in infants and children. Ann Allergy 1987:59:137-140.

7. Gerrard JW, MacKenzie JWA, Goluboff N, Garson JZ, Maningas CS. Cow's milk allergy: prevalence and manifestations in an unselected series of newborns. Acta Paediatr Scand 1973;234 suppl:1-21.

8. Goldman AS, Anderson DW, Sellers WA, Saperstein S, Kniker WT, Halpern SR. Oral challenge with milk and isolated milk proteins in allergic children. Pediatrics 1963; 32:425-443.

9. Hill DJ, Davidson GP, Cameron DJS, Barnes GL. The spectrum of cow's milk allergy in childhood. Acta Paediatr Scand 1979;68:847-852.

10. Hill DJ, Firer MA, Ball G, Hosking CS. Recovery from milk allergy in early childhood: Antibody studies. J Pediatr 1989; 1 14:761-766.

11. Ishizaka K, Ishizaka T, Hombrook MM. Physiochemical properties of human reagenic antibody: IV Presence of a unique immunoglobulin as a carrier of reagenic activity. J Immunol 1966;97:75-79.

12. Jakobsson 1, Lindberg T. A prospective study of cow's milk protein intolerance in swedish infants. Acta Paediatr Scand 1979;68:853-859.

13. Kjellman N-I M. Immunoglobulin E and atopic allergy in childhood. Linkoping University Medical Dissertions 1976:36.

14. Kjellman N-I M. Predictive value of high IgE levels in children. Acta Paediatr Scand 1976:65:465-471.

15. Kjellman N-1 M. Bjorkstein B, Hattevig G, Falth-Magnusson K. Natural history of food allergy. Ann Allergy 1988;61:83-87.

16. Kletter B, Gerry I, Freier S, Noah Z, Davies MA. Immunoglobulin E antibodies to milk proteins. Clin Allergy 1971;I:249-255.

17. Kuitunen P, Visakorpi JK, Savilahti E, Pelkonen P. Malabsorption syndrome with cow's milk intolerance. Arch Dis Childh 1975;50:351-356.

18. Lindberg RE, Arroyave PhD. Levels of $\mathrm{IgE}$ in serum from normal children and allergic: children as measured by an enzyme immunoassay. J Allergy Clin Immunol 1986; 78:614-618.

19. Rzany B, Jarisch R, Gotz M. Spezifische IgE-antikörper gegen Kuhmilchproteine bei Kinder mit Verdacht auf Kuhmilchallergie. Monatsschr Kinderheilkd 1986;134:799.. 803 .

20. Sampson HA, Scanlon SM. Natural history of food hypersensitivity in children with atopic dermatitis. J Pediatr 1989:115:23-26. 


\section{Chapter 8}

\section{GENERAL DISCUSSION}

Cow's milk protein intolerance (CMPI) is a condition presenting with such clinical heterogeneity that no firm agreement has yet been reached as far as diagnostic criteria are concerned. This lack of standardized diagnostic criteria has resulted in widespread differences in reported incidence rates of CMPI and in management approaches used with infants "suspected" of CMPI. The consequence of the latter is that in some areas in the Netherlands, a large percentage of all infants are being given a soy-millk substitute because of possible CMPI while, in other areas, the same disease is considered too exceptional to justify dietary changes in infants with very similar symptoms.

The present work represents an effort to evaluate both the incidence rate of CMPI in the region Maastricht, making use of the best-accepted diagnostic test (milk elimination/challenge tests), as well as the clinical usefulness of various anamnestic and laboratory findings.

We divided our patients into two groups: sick control infants (patients with symptoms possibly due to cow's milk intolerance in which CMPI and lactose intolerance was excluded) and infants with CMPI.

In a preliminary study, we first had to establish whether or not three successive milk elimination/challenge tests, as originally proposed by Goldman et al (6), were strictly needed for the diagnosis. Our results showed that only one elimination of cow's milk, or one elimination/challenge test, was clearly insufficient and led to many diagnostic errors: respectively $50 \%$ and $20 \%$ over-diag . nosis. Performing two milk elimination/challenge tests led in most cases to a correct diagnosis. The latter procedure was consequently used in our study population.

The incidence of CMPI in our study population of 1158 infants was $2.8 \%$, which is on the low end of the range reported by several authors in the literature $(0.3 \%$ to $10 \%)(5,8)$. Although several factors could contribute to the difference found between our results and those of other authors, the main reason lies, in our opinion, in the different diagnostic criteria used in the various studies. 
A surprising finding of our study was the large group of infants (about $30 \%$ ) mainly with gastrointestinal complaints who improved on low-lactose feeding. Although we do not have a ready explanation for this finding, since most authors do not think of lactose as a cause of intolerance to cow's milk in infants, it could at least partially explain the success claimed by the many physicians who frequently prescribe soymilk (no lactose content) for infants with aspecific gastrointestinal complaints. We assume that many of these babies would do as well on an ordinary low-lactose milk formula, avoiding the use of soymilk or expensive protein hydrolysate based formulas.

Several authors have compared the prevalence of atopy in families of CMPI children with families of healthy infants. In ous prospective epidemiological study, we compared the prevalence of atopy in families of CMPI children with both healthy infant families and sick infant control families. Similarly to what other authors reported, we found a significant increase in the prevalence of family atopy in one first-degree relative in our CMPI infants group (54\%) when compared to our healthy infants $(24 \%$ ( $p<0.005)$. No differences were found in CMPI (54\%) and sick control families (49\%). When considering two atopic first degree relatives as the criterium for family atopy could we find a difference in the prevalence of family atopy between our CMPI (19\%) and our sick control group $(5 \%)(p<0.05)$. The antecedent of family history have, according to our results, a low discriminatory value.

The effect of dietary interventions in infants for prevention of CMPI and atopic disease has been studied extensively and reported in more than 50 articles. Antigen avoidance during pregnancy does not result in a decreased incidence of CMPI and atopy in infants (4). Many studies claim good short term results of antigen avoidance during the first three or six months of life in children at risk for allergy development. Few long term studies have been performed. Several studies use ill defined allergy groups such as family history positive for allergy. For our epidemiological study the risk groups are very difficult to define. If we considered one first degree atopic relative as indicative for allergy risk there were 296/1107 infants at risk. Considering two or more first degree relatives as criterium then 55/1107 infants would qualify for preventive measures. Interesting only $19 \%$ of the infants with CMPI and $5 \%$ of the sick controls in our study would have been selected for a preventive study. Chandra (3) reported the cost-benefit ratio of allergy prevention programs regarding the health problems of atopic persons and preventive programs. He claimed that preventive strategies would be cost-effective if atopy frequency could be reduced by $20 \%$. It is too early to advocate either antigen avoidance during lactation or hypoallergenic prophylactic formulas in all atopic families to prevent the development of atopy. Perhaps combined allergen avoidance, dietary measures for the lactating mother as well as decreased exposure to house dust mite and smoking will influence the incidence of atopic manifestations in the child (2). 
We mainly tried to evaluate the clinical usefulness of serum IgE and RAST for cow's milk, as well as that of duodenal biopsy IgE plasma cells in our infant population. Serum IgE and RAST were increased in 61 and 38 of the 104 CMPI infants opposed to 43 and $11 \mathrm{IgE}$ and RAST positivity in 114 sick controls. These differences were significant $(p<0.003$ and $p<0.0001)$. Based on our data, the sensitivity of $\mathrm{IgE}$ and RAST would be $59 \%$ and $37 \%$ respectively, while specificity for $\mathrm{IgE}$ and RAST would be $38 \%$ and $90 \%$. Literature results concerning immunological tests show very wide variations. Sensitivity for cow's milk RAST varies from $44 \%$ to $88 \%$ and specificity from $35 \%$ to $87 \%$. These differences in results are mostly due to patient selection (patients with dermal versus gastrointestinal manifestations, for instance) and age differences, which both have profound influences on IgE and RAST results. Our results are in agreement with literature data on unselected patient groups.

Making use of the likelihood-ratio method for the interpretation of our results, we concluded that RAST results were of some use for the diagnosis of CMPI in the presence of either a negative family history or of only one first-degree relative who was found to be atopic. In the few CMPI infants with two atopic first-degree relatives we studied, RAST results did not contribute to an improvement of our diagnostic accuracy.

IgE levels, on the other hand, only slightly improved the likclihood ratio and were consequently not found useful for the CMPI diagnosis.

Our results showing the frequent presence of increased numbers of $\operatorname{IgE}$ plasma cells in duodenal biopsies of CMPI patients are quite interesting. We have shown that intestinal mucosal IgE plasma cells can be found in infants with CMPI even in the absence of increased serum IgE and positive RAST results.

Most authors rely on serum IgE and RAST results and on skin prick tests for the diagnosis of "allergy". By so doing, the possibility of local IgE mediated reactions is completely neglected, which could result in an underestimation of the frequency of gastrointestinal allergic reactions. We think this approach should be pursued further in order to better investigate the relative contribution of IgE-mediated allergy to CMPI.

Since it has been suggested that an increased intestinal permeability to food antigens could be an important factor in the development of CMPI, we investigated gut permeability in these patients, making use of 51-Cr EDTA as permeability marker. Our results show permeability to be increased in CMPI patients compared to control patients. Although we did not measure permeability after healing of CMPI, other authors $(1,7)$, making use of sugar permeability markers, showed that increased permeability reverted to normal after healing and increased again after a positive cow's milk challenge test. Our findings could explain the reported development of milk intolerance after an 
episode of gastroenteritis in young infants, as the latter disease is known to be associated with increased gut permeability to both antigens and permeability markers such as 51-Cr EDTA or sugar molecules.

Although serum IgE and RAST were not very useful in the initial diagnosis of our patients, our prospective study showed an initial serum-IgE level higher than $10 \mathrm{kU} / \mathrm{L}$ to be significantly predictive of longer lasting clinical complaints in our CMPI infants. At the age of four years $90 \%$ of infants with initial IgE levels $<10 \mathrm{kU} / \mathrm{l}$ had become tolerant for cow's milk while this was the case for only $47 \%$ of the infants with initial $\operatorname{lgE}$ levels $\geq 10 \mathrm{kU} / \mathrm{l}$. This aspect has not been extensively studied before and should be helpful for prognostic evaluation of individual patients. We could not show a relationship between initial RAST results and healing rate. We also showed that CMPI commonly lasts ionger than is usually recognized in the literature. At the age of 4 years, $33 \%$ of the children were still cow's milk intolerant.

In conclusion clinical recognition of CMPI is very difficult because CMPI is a heterogeneous disorder. There is no specific single symptom nor pattern of symptoms which is pathognomonic for CMPI. Today the lack of an accepted golden standard for the diagnosis still constitutes the main problem in studying/treating infants with CMPI. The use of a sick control group instead of a healthy control group makes the evaluation of various diagnostic test procedures more realistic and reliable. 


\section{REFERENCES}

1. André C, André F, Colin L, Cavagna S. Measurement of intestinal permeability to mannitol and lactulose as a means of diagnosing food allergy and evaluating therapeutic effectiveness of disodium cromoglycate. Ann Allergy 1987;59:127-130.

2. Arshad Sh, Matthews S, Gant C, Hide DW. Effect of allergen avoidance of development of allergic disorders in infancy. Lancet 1992:339:1493-1497.

3. Chandra RK. Nahrungsmittelallergie: 1992 und danach. Sozialpaldiatrie in der Puddiatrie 1993;15 suppl:232-237.

4. Falth-Magnusson K, Kjellman MD. Development of atopic disease in babies whose mothers were receiving exclusion diet during pregnancy. A randomized study, J Allergy Clin Immunol 1987;80:868-875.

5. Gerrard JW, MacKenzie JWA, Goluboff N, Garson JZ, Maningas CS, Cow's milk allergy: prevalence and manifestations in an unselected series of newborns. Acta Paediatr Scand 1979;234 suppl:1-21.

6. Goldman A, Anderson DW, Sellers WA, Saperstein S, Kniker WT, Halpern SR. Milk allergy: I. Oral challenge with milk and isolated milk proteins in allergic children. Pediatrics 1963;32:425-443.

7. Jalonen $T$. Identical intestinal permeability changes in children with different clinical manifestations of cow's milk allergy. J Allergy Clin Immunol 1991;88:737-742.

8. Wood C. How common is food allergy? Acta Paediatr Scand 1986;323 suppl:76-83. 



\section{Chapter 9}

\section{SUMMARY}

A historical perspective and a review of the literature on CMPI is presented in Chapter 1. Reports concerning CMPI were scanty in the period $1900-1960$. Due to the fact that most reported studies took only the most severe reactions into consideration, it was thought to be a rare disease. In 1963, for the first time, Goldman gave a detailed description of milk intolerance symptoms in a large group of children and established clear diagnostic criteria for CMPI. Controversies on CMPI terminology are discussed. The chapter also describes the clinical manifestations and the diagnostic criteria pointing out the lack of objective and reproducible diagnostic tests. The latter part of the chapter deals with prevention and therapy and stresses the fact that several questions concerning cow's milk protein intolerance still remain unanswered.

In Chapter 2 the aims of the study are presented.

Literature data on the incidence of CMPI show a wide variability $(0.3 \%$ $10 \%$ ). Various diagnostic tests for CMPI have been used with different results. Several studies compare results of diagnostic tests for CMPI to healthy rather than sick control groups. We decided to divide our patients into two groups: sick control infants (patients with symptoms possibly due to cow's milk intolerance in which CMPI and lactose intolerance was excluded) and infants with CMPI. Consequently we first aimed at establishing the incidence rate of CMPI in our regional infant population and secondly at evaluating various diagnostic tests in three prospective studies: a. Family history for atopy, serum $\operatorname{IgE}$ level and specific RAST for cow's milk, b. Small bowel mucosa IgE plasma cells and specific RAST for cow's milk, c. 51-Cr EDTA intestinal permeability test. Thirdly and finally, we studied the prognosis of CMPI and the correlation of initial serum IgE level and cow's milk RAST with the healing rate.

In Chapter 3 results of the prospective epidemiological study are reported. 1158 infants were followed from birth to one year of age and examined for symptoms of CMPI. After exclusion of lactose intolerance, two pusitive cow's milk 
elimination/challenge tests were considered diagnostic of CMPI. Possible symptoms of CMPI were found in 244 infants. CMPI could be confirmed in 26/244 infants. The calculated incidence rate for CMPI was $2.8 \%$. Therefore in the Netherlands 5600 infants will develop CMPI yearly. Gastrointestinal, dermatological and respiratory symptoms were the main symptoms observed in our infants with CMPI and occurred with a frequency of $50 \%, 31 \%$ and $19 \%$ respectively. A positive family history for atopy (first-degree or second-degree relatives) was more frequent in both CMPI infants and sick controls when compared to healthy controls. It was very difficult to differentiate between symptomatic infants with and without CMPI on the basis of clinical data. Only the presence of multi-organ symptoms and/or a positive family history in two first-degree relatives weakly discriminated. The large number of symptomatic infants displaying gastrointestinal symptoms who did well on a low-lactose formula was puzzling, since most studies provide no support for the role of lactose intolerance in infants with gastrointestinal complaints. Giving a low-lactose formula to these infants before introducing a cow's milk free diet could prevent the costly prescription of soy or hydrolysed formulas.

A large percentage of infants with CMPI ( $46 \%$ in our study) cried more than two hours a day. However, in infants with crying as a cardinal symptom, CMPI was confirmed in $6 \%$ only.

In Chapter 4 results of our study which aimed at evaluating the diagnostic value of family history for atopy, total IgE and cow's milk RAST in children with symptoms possibly due to CMPI are presented. Because the likelihood ratio expresses the odds that a given level of a diagnostic test result would be expected in a patient with CMPI (as opposed to one without), we used this practical method for the evaluation of the mentioned diagnostic test procedures. The calculated likelihood ratio was 3.9 for a family history of atopy among two first-degree relatives. A positive RAST result increased the odds of CMPI by a factor of 3.8. A IgE level $\geq 10 \mathrm{kU} / 1$ did not improve diagnostic accuracy. The RAST result would be mainly useful in a population with a high prevalence of CMPI and in the presence of either a negative family history for atopy or atopy in one first-degree relative. Negative data on family history for atopy or negative results of $\operatorname{lgE}$ and RAST had no predictive value. Due to the lack of reliable anamnestic and diagnostic data, two elimination/challenge tests remain the cornerstone for the diagnosis of CMPI in infants.

In Chapter 5 we present the results of a study concerning small intestinal mucosal IgE plasma cells and specific anti-cow's milk IgE in children with CMPI. Neither of these diagnostic procedures was sensitive enough to be used as a screening test for CMPI. Furthermore, the relationship between specific IgE antibodies for cow's milk and the presence of mucosal IgE plasma cells was 
poor: approximately $50 \%$ of the infants with CMPI, in whom mucosal IgE plasmocytes were present, had a negative RAST for cow's milk. We showed that intestinal mucosal $\mathrm{lgE}$ plasma cells can be found in patients with CMPI even in the absence of positive RAST. The frequency of IgE-mediated reactions is probably higher than could be inferred from serum $\operatorname{lgE}$ and RAST results.

In Chapter 6 results of intestinal permeability studies in children with possible CMPI are presented. Patients with CMPI showed a significantly increased small bowel permeability when compared to both the sick and healthy control groups. Our results support the possible role of disruption of the mucosal barrier in infants with $\mathrm{CMPI}$; increased permeability and enhanced penetration of antigens leading in some infants to immunologically mediated reactions.

In Chapter 7 we describe a long-term follow-up study of CMPI infants. Infants with CMPI were followed over a period of four years in order to evaluate the persistence of CMPI and the relationship between the persistence of CMPI and either initial serum IgE level or RAST for cow's milk. At the age of four years, $33 \%$ of the children were still cow's milk intolerant. Initial serum values of $\mathrm{gEE}$ $\geq 10 \mathrm{kU} / \mathrm{l}$ indicated a late development of tolerance to cow's milk proteins. At the age of four years, $90 \%$ of infants with initial $\operatorname{IgE}$ levels $<10 \mathrm{kU} / \mathrm{l}$ had become tolerant for cow's milk, while this was the case for only $47 \%$ of the infants with initial IgE levels $\geq 10 \mathrm{kU} /$. Initial RAST results for cow's milk bore no obvious relationship to outcome. 



\section{Chapter 10}

\section{SAMENVATTING}

In hoofdstuk 1 wordt koemelkeiwit-overgevoeligheid in historisch perspectief geplaatst en wordt de literatuur besproken. In de periode 1900 - 1960 verscheen een gering aantal publikaties. Omdat alleen de ernstige reakties op koemelk gepubliceerd werden veronderstelde men dat de aandoening zeldzaam was. in 1963 beschreef Goldman gedetailleerd de symptomen van koemelkeiwit-overgevoeligheid bij een grote groep kinderen; voor de eerste maal in de literatuur werden duidelijke criteria voor de diagnose gegeven. De terminologie is onderdeel van de controversen die over koemelkeiwit-overgevoeligheid bestaan. In dit hoofdstuk wordt verder ingegaan op de symptomatologie, de meest verrichte testen en de diagnostische criteria. Het ontbreken van objectieve en reproduceerbare testen wordt benadrukt. Hiema worden preventie en therapie besproken. Er blijven diverse vragen over koemelkeiwit-overgevoeligheid onbeantwoord.

In hoofdstuk 2 worden de doelstellingen van de studie besproken. Literatuur gegevens tonen een forse spreiding van de incidentie van koemelkeiwit-overgevoeligheid. Verschillende diagnostische testen zijn bekend, echter zonder consistente conclusies. Bij het vergelijken van resultaten van diagnostische testen gaat men uit van kinderen met koemelkeiwit-overgevoeligheid in vergelijking tot een vaak gezonde controlegroep. Wij besloten een zieke controle groep te gebruiken: kinderen met symptomen mogelijk ten gevolge van koemelkintolerantie, waarbij lactose-intolerantie was uitgesloten. Ten eerste wilden wij de incidentie van koemelkeiwit-overgevoeligheid bepalen. Ten tweede wilden wij in drie prospectieve studies een aantal diagnostische gegevens onderzoeken: a: de familie anamnese voor atopie, serum IgE nivo en RAST, b: IgE plasmacellen in het dunne darmslijmvlies en de specifieke RAST voor koemelkeiwit, c: Darm permeabiliteitsonderzoek door middel van $51 \mathrm{Cr}$ EDTA. Ten derde werd de prognose van koemelkeiwit-overgevoeligheid bestudeerd. Tevens werd bestudeerd in hoeverre het initiële serum IgE nivo en de specifieke RAST vonr koemelkeiwit van invloed waren op de mate van herstel. 
In hoofdstuk 3 wordt de prospectieve epidemiologische studie besproken. 1158 kinderen werden vanaf de geboorte tot de leeftijd van 1 jaar gevolgd en onderzocht op symptomen van koemelkeiwit-overgevoeligheid. Na uitsluiting van lactose intolerantie werd de diagnose koemelkeiwit-overgevoeligheid door middel van twee positieve eliminatie/challenge testen met koemelk geaccepteerd. Bij 244 kinderen werden symptomen gevonden die konden passen bij koemelkeiwit-overgevoeligheid. Bij 26/244 werd de diagnose gesteld. De berekende incidentie van koemelkeiwit-overgevoeligheid was $2.8 \%$. Per jaar zullen in Nederland 5600 zuigelingen koemelkeiwit-overgevoeligheid ontwikkelen. De belangrijkste symptomen waren respectievelijk gastrointestinaal $(50 \%)$, dermatologisch $(31 \%)$ en respiratoir $(19 \%)$. Een positieve familie anamnese voor atopie (zowel bij eerste- als tweedegraads familieleden) kwam vaker voor bij koemelkeiwitovergevoelige patiënten en bij zieke controles in vergelijking met gezonden. Bij zuigelingen met symptomen was het zeer moeilijk om te differentiëren tussen wel cq geen koemelkeiwit-overgevoeligheid; alleen multiorgaan problematiek en/of een positieve familie anamnese bij twee eerstegraads familieleden hadden een zwakke discriminerende waarde. Opvallende bevinding was dat een groot aantal kinderen met een lactosearme voeding klachtenvrij was; deze kinderen hadden met name gastro intestinale klachten. In de meeste studies over de jonge zuigelingengroep wordt namelijk geen lactoseintolerantie beschreven. Voordat een koemelkvrij dieet gegeven wordt aan zuigelingen met gastrointestinale klachten dient een lactosearme voeding te worden gegeven. Dit kan voorkomen dat er kostbare soya- of gehydrolyseerde voedingen voorgeschreven worden. Een hoog percentage kinderen met koemelkeiwit-overgevoeligheid huilde meer dan twee uur per dag (46\%). Bij 6\% van de kinderen met huilen als belangrijkste klacht stelden wij de diagnose koemelkeiwit-overgevoeligheid.

In hoofdstuk 4 beschrijven wij de diagnostische waarde van de familie anamnese gericht op atopie, totaal IgE en koemelk RAST bij kinderen, verdacht van koemelkeiwit-overgevoeligheid. Met behulp van de likelihood ratio wordt naar een mogellijke kans verhoging gekeken van de diagnostische gegevens. Wij gebriikten deze praktische methode voor de evaluatie van de bruikbaarheid van de aanvullende diagnostische gegevens. Bij een kind met twee eerstegraads atopische familieleden bleek de likelihood ratio voor koemelkeiwit-overgevoeligheid 3.8. Een positieve RAST verhoogde de kans op koemelkeiwit-overgevoeligheid in onze onderzoekspopulatie met een factor 3.8. Een IgE gehalte $\geq 10 \mathrm{kU} / \mathrm{l}$ had geen diagnostische waarde. De RAST gegevens bleken voomamelijk bruikbaar als de prevalentie van koemelkeiwit-overgevoeligheid op een polikliniek hoog is en de familie anamnese voor atopie negatief was of alleen positief bij één eersiegraads familielid. Negatieve gegevens over atopie in de familie of een negatieve IgE en RAST bleken geen predictieve waarde te 
hebben. Door het gebrek aan betrouwbare anamnestische - en diagnostische gegevens blijven twee eliminatie/challenge testen nodig om te differentiëren tussen kinderen met symptomen.

In hoofdstuk $\mathbf{5}$ presenteren wij de resultaten van een studie naar IgE plasma cellen in de dunne darm mucosa en de RAST voor koemelk. Geen van deze diagnostische testen was gevoelig genoeg om als screeningstest gebruikt te worden. De correlatie tussen de RAST uitslag voor koemelk en de $\operatorname{lgE}$ plasma cellen was slecht: bij ongeveer $50 \%$ van de kinderen die IgE plasma cellen in de darm mucosa hadden was de RAST negatief. Aangetoond werd dat mucosale IgE plasma cellen bij koemelkeiwit-overgevoelige kinderen gevonden kunnen worden zonder abnormale RAST resultaten. Er blijken meer IgE gemedieerde reacties op koemelk te bestaan dan men met het serum IgE nivo en de RAST kan aantonen.

In hoofdstuk 6 worden de resultaten van een dunne darm permeabiliteitstest gepresenteerd. Er bestond een significant verhoogde darmpermeabiliteit bij koemelkeiwit-overgevoelige kinderen ten opzichte van zieke en gezonde controles. Deze conclusie ondersteunt de hypothese dat de doorlaatbaarheid van de mucosa van de darm bij kinderen met een koemelkeiwit-overgevoeligheid verhoogd is. De toegenomen permeabiliteit heeft een verhoogde penetratie van antigenen tot gevolg die bij sommige kinderen zal leiden tot afwijkende immunologische reakties.

In hoofdstuk 7 beschrijven wij een langdurig follow up onderzoek bij koemelkeiwit overgevoelige kinderen; tevens onderzochten wij de prognose van koemelkeiwit-overgevoeligheid in relatie tot het initiële serum IgE nivo of de RAST voor koemelk. Op de leeftijd van 4 jaar waren nog 33\% van de kinderen koemelkeiwitovergevoelig. IgE waarden $\geq 10 \mathrm{kU} / 1$ (bij de diagnose in het eerste levensjaar bepaald) bleken gerelateerd aan een late ontwikkeling van tolerantie $(47 \%)$. Kinderen met een IgE waarde $<10 \mathrm{kU} / \mathrm{l}$ bleken op de leeftijd van 4 jaar in $90 \%$ van de gevallen tolerant geworden; de meeste kinderen uit deze groep hadden maagdarmklachten. De uitslagen van de RAST bleken zonder prognostische betekenis. 


\section{NAWOORD}

Interesse in de problematiek van voedselovergevoeligheid is ontstaan tijdens mijn opleiding tot kinderarts. Samen met prof,dr, G.A. de Jonge en dr. A.C. Douwes heb ik toen mijn eerste artikel over voedsel overgevoeligheid geschreven. Adriaan, jij hebt mijn interesse voor voedsel overgevoeligheid gewekt en bent, waarschijnlijk zonder dat je dit realiseert, één van de aanstichters van het promotie onderzoek geweest.

In 1984 begon ik in Maastricht als waarnemer van drs. Th. van der Kley. Prof.dr. L.H.J. Ramaekers zaliger was toen samen met dr. P.P. Forget en drs. A. Kuppevelt (toen nog arts-assistent kindergeneeskunde), bezig met de opzet van een epidemiologische studie naar voedselovergevoeligheid bij zuigelingen. Omdat hij al snel als kinderarts in Doetinchem kon beginnen, was het duidelijk dat collega Kuppevelt deze epidemiologische studie niet uit kon voeren. Prof. Ramaekers herkende mijn interesse in voedselovergevoeligheid en stimuleerde mij om de studie uit te voeren en deze uit te breiden tot een promotie-onderzoek. Hij zou mijn eerste promotor geweest zijn. Helaas is hij tijdens de startperiode overleden. Met Philippe Forget gaf hij mij alle vrijheid om naast het vrijwel volledig uitgezette epidemiologische onderzoek naar koemelkeiwitovergevoeligheid, het promotie onderzoek uit te stippelen. Juist door deze vrijheid heb ik het onderzoek met beide handen aangegrepen.

Speciale dank ben ik verschuldigd aan:

Prof.dr. R.H. Kuijten heeft, na een periode van een aantal jaren waar de vakgroep geen hoogleraar had, de fakkel van prof. Ramaekers overgenomen. Beste René, met jou heb ik op een rij kunnen zetten welke onderdelen deel uit zouden gaan maken van mijn proefschrift, bedankt voor je kritische opmerkingen.

Dr. P.P. Forget heeft mij vanaf het begin van het proefschrift zeer geholpen heeft. Philip, ik ben je zeer dankbaar voor je krachtige stimulans vooi de voortgang van het onderzoek, voor je inhoudsdeskundige commentaar en creatieve begeleiding.

Prof.dr. C. Blanco, beste Carlos, ik wil je speciaal danken voor je kritische opmerkingen en kanttekeningen bij de diverse versies van het proefschrift.

Een belangrijk deel van dit proefschrift is tot stand gekomen door de fantastische inzet van vier consultatiebureau artsen, te weten mw.drs. A.T. van der Linden-Kuiper, mw.drs. D.T.A.M. Hutschemaekers-Oostendorp, mw.drs. G.A. 
Vermeulen-van der Meer en mw.drs. A.J.C. Hanekamp-Veldman. Zonder jullie was het epidemiologie artikel niet tot stand gekomen. Een flinke periode hebben jullie vieren vrijwel het onderzoek gedragen. Ik ben jullie daar zeer erkentelijk voor. Mw.drs. M.L.I.E. Ausems-van Herten, beste Tielke, met jou heb ik de organisatorische contacten gehad. Ik ben dankbaar voor je medewerking en steun.

De begeleiding door dr. A. Kester, statisticus, was hoog nodig gezien mijn volledige onbekendheid met deze materie. Arnold, mijn hartelijke dank voor je inzet en geduld.

Een flink aantal $3 \mathrm{e}, 4 \mathrm{e}$ en $6 \mathrm{e}$ jaars wetenschaps-studenten geneeskunde zijn met de uitwerking van het verzamelde materiaal voor dit proefschrift bezig geweest, waarvoor mijn dank. Van deze studenten wil ik met name Sylvia Oudsen, John Dellevoet, John van de Bogart, Edgar van Mill en Renée UnsalanHooyen noemen; zij hebben een essentiële bijdrage geleverd en ik ben hen voor hun inzet zeer erkentelijk.

Dr. S. v.d. Meer, beste Syb, bedankt voor je medewerking en stimulans; door zelf naast al je werkzaamheden zo snel te promoveren op het buikpijn onderzoek gaf je mij een extra push om mijn promotie onderzoek af te ronden.

Natuurlijk ben ik al mijn direkte collegae dankbaar voor de belangstelling en collegiale houding.

Heidi Bish en later Eveline Lipsch, mijn secretaresses, ben ik grote dank verschuldigd. Jullie hebben de eindeloze versies bijgewerkt en tabellen gemaakt die bij mij nooit fatsoenlijk uit de printer kwamen.

De patiëntjes en hun ouders hebben mij zeker in eerste instantie meer geleerd van het onderwerp voedselovergevoeligheid dan alle 2000 artikelen over dit onderwerp. Zonder hen was het onderzoek niet mogelijk geweest en ik dank hen voor het vertrouwen en de stimulans.

Mijn echtgenote heeft zeer vele weekeinden alleen de kinderen op moeten vangen, omdat vader achter de computer moest. Constance, je stimulans, geduld èn je hulp bij het vervaardigen van dit proefschrift waren essentieel voor het eind resultaat. Waarschijnlijk was het boekje er zonder jou niet gekomen.

Dirk en Anna, ik heb mij vaak in de Joeter kamer terug moeten trekken en als tegenprestatie voomamelijk zeer veel tekenpapier aangeleverd. Gelukkig is de tijd om samen, met z'n vieren, allerlei dingen te ondernemen nu weer gekomen. 


\section{CURRICULUM VITAE}

De schrijver van dit proefschrift werd op 10 juli 1952 te Amsterdam geboren. In 1969 ontving hij het diploma MULO A met wiskunde. In 1972 werd het eindexamen HBS B aan het Snellius Lyceum in Amstelveen gehaald.

Vanaf 1972 studeerde hij geneeskunde aan de Vrije Universiteit Amsterdam waar hij in december 1979 het artsexamen deed. Tijdens zijn geneeskunde studie is hij 2 jaar studenten mentor en 4 jaar studenten assistent interne geneeskunde geweest bij achtereenvolgens prof.dr. J. Stam, prof.dr. L. Gooren, dr. J. Schouten en prof.dr. G. Thijs.

Van 1980-1984 heeft hij zich onder leiding van prof.dr. G.A. de Jonge in de kindergeneeskunde gespecialiseerd. Het laatste half jaar van de opleiding bracht hij door bij de collegae H. Dijkhuis, A. v. Rhijn en J.A. Scholten te Amersfoort. Tijdens zijn opleiding pediatrie deed hij een wetenschapsstage "voedselallergie bij zuigelingen" bij dr. A.C. Douwes in het Academisch Ziekenhuis van de Vrije Universiteit.

Vanaf 6 februari 1984 tot 1 april 1985 nam hij waar in ziekenhuis Annadal te Maastricht. Vanaf 1 april 1985 is hij als staflid verbonden aan de kinderafdeling van het Academisch Ziekenhuis Maastricht. Vanaf 1986 - 1993 was hij tevens als kinderarts werkzaam bij het Medisch Orthopedagogisch Kindertehuis Overbunde.

Op 22 juni 1977 is hij getrouwd met Connie Stumpel. Zij hebben twee kinderen, Dirk en Anna. 

